\title{
AVALIAÇÃO DO POTENCIAL FISIOLÓGICO DE SEMENTES DE MILHO ATRAVÉS DO TESTE DE LIXIVIAÇÃO DE POTÁSSIO
}

\author{
MARIANE VICTORIO DE CARVALHO MIGUEL \\ Engenheira Agrônoma
}

Orientador: Prof. Dr. JULIO MARCOS FILHO

Tese apresentada à Escola Superior de Agricultura "Luiz de Queiroz", Universidade de São Paulo, para obtenção do título de Doutor em Agronomia, Área de Concentração: Fitotecnia.

\author{
PIRACICABA \\ Estado de São Paulo - Brasil \\ Fevereiro - 2001
}




\title{
Dados Internacionais de Catalogação na Publicação (CIP) DIVISÃO DE BIBLIOTECA E DOCUMENTAÇÃO - Campus "Luiz de Queiroz"/USP
}

\author{
Miguel, Mariane Victorio de Carvalho \\ Avaliação do potencial fisiológico de sementes de milho através do teste de \\ lixiviação de potássio / Mariane Victorio de Carvalho Miguel. - - Piracicaba, 2001. \\ $113 \mathrm{p}$. \\ Tese (doutorado) - - Escola Superior de Agricultura Luiz de Queiroz, 2001. \\ Bibliografia. \\ 1. Lixiviação 2. Potássio 3. Semente de milho 4. Teste de vigor I. Título
}

CDD 633.15 


\section{DEDICO}

Aos meus pais, Nelson e Rozilde

À minha irmã Ludmila

Ao Marcelo H. Miguel pelo exemplo de vida 


\section{AGRADECIMENTOS}

A Deus, pela vida.

Ao Prof. Dr. Julio Marcos Filho, pelos anos de amizade, orientação e contribuição fundamental na minha formação profissional.

Aos professores de Curso de Pós-Graduação em Fitotecnia, em especial aos professores Silvio Moure Cicero e Walter Rodrigues da Silva, pela amizade e ensinamentos.

Às engenheiras Agrônomas Ana D.C.L. Novembre e Helena M.C.P. Chamma, pela colaboração e amizade.

À Coordenação de Aperfeiçoamento de Pessoal de Nivel Superior (CAPES), pela concessão da bolsa de estudos.

Ao Conselho Nacional de Desenvolvimento Científico e Tecnológico (CNPq), pela concessão da bolsa de estudos.

Às Empresas Agroceres S/A e Novartis S/A, pelo fornecimento das sementes.

Aos funcionários do Departamento de Produção Vegetal, pela contribuição na execução dessa pesquisa.

Aos funcionários da Biblioteca Central da ESALQ/USP, em especial à funcionária Sílvia Zinsly, pela valiosa correção das referências bibliográficas. 
Aos companheiros do Curso de Pós-Graduação, pelos anos de convivência. 


\section{SUMÁRIO}

Página

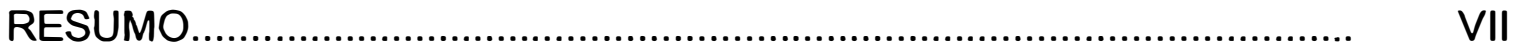

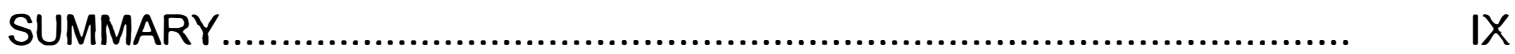

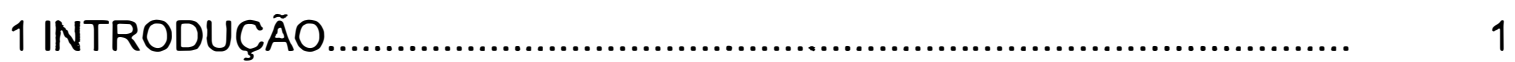

2 REVISÃO DE LITERATURA.......................................................... 3

2.1 Deterioração de sementes........................................................ 3

2.2 Membranas celulares e queda do potencial fisiológico das

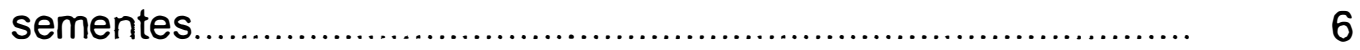

2.3 Testes de vigor baseados na permeabilidade de membranas...... 11

3 MATERIAL E MÉTODOS............................................................... 19

3.1 Avaliações preliminares............................................................. 19

3.2 Lixiviação de potássio.................................................................. 22

3.2.1 Preparo das amostras...................................................... 22

3.2.2 Leituras da lixiviação de potássio........................................ 22

3.2.3 Cálculo da quantidade de potássio exsudado pelas

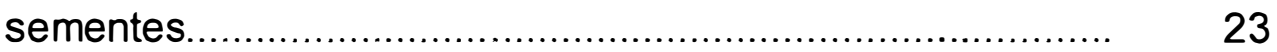

3.2.4 Teste de lixiviação de potássio........................................... 23

3.3 Análise da composição química das sementes e da solução de embebição ............................................................................. 24

3.4 Procedimento estatístico........................................................ 25

4 RESULTADOS E DISCUSSÃO.................................................................... 27

4.1 Calibração do fotômetro de chama............................................... 27

4.2 Avaliações preliminares do potencial fisiológico dos lotes............ 29

4.2.1 Hibrido Avant...................................................................... $\quad 29$

4.2.2 Hibrido AG 6690.......................................................... 31

4.2.3 Hibrido Traktor............................................................... $\quad 33$ 
4.2.4 Teor de água das sementes............................................. $\quad 35$

4.2.5 Considerações Gerais..................................................... 37

4.3 Lixiviação de Potássio.................................................................. 38

4.3.1 Hibrido Avant................................................................. 38

4.3.1.1 Testes de lixiviação de potássio realizados a $25^{\circ} \mathrm{C}$.. $\quad 38$

4.3.1.2 Testes de lixiviação de potássio realizados a $30^{\circ} \mathrm{C}$.. $\quad 46$

4.3.2 Hibrido AG 6690.......................................................... 53

4.3.2.1 Testes de lixiviação de potássio realizados a $25^{\circ} \mathrm{C}$.. $\quad 53$

4.3.2.2 Testes de lixiviação de potássio realizados a $30^{\circ} \mathrm{C}$.. $\quad 64$

4.3.3 Hibrido Traktor................................................................ $\quad 70$

4.3.3.1 Testes de lixiviação de potássio realizados a $25^{\circ} \mathrm{C} . . \quad 70$

4.3.3.2 Testes de lixiviação de potássio realizados a $30^{\circ} \mathrm{C}$.. $\quad 77$

4.3.4 Considerações gerais....................................................... 82

4.4 Relações entre a lixiviação de potássio e as alterações de temperatura, períodos de embebição, número de sementes e volume de embebição.

4.4.1 Temperatura ................................................................ 86

4.4.2 Períodos de Embebição................................................... 88

4.4.3 Número de Sementes..................................................... $\quad 89$

4.4.4 Volume de embebição.......................................................... 91

4.4.5 Considerações Gerais...................................................... 93

4.5 Análise química das sementes e das soluções de embebição.... 94

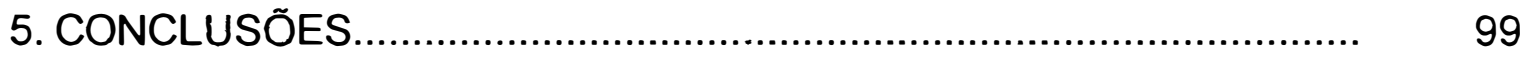

REFERÊNCIAS BIBLIOGRÁFICAS................................................. 100 


\title{
AVALIAÇÃO DO POTENCIAL FISIOLÓGICO DE SEMENTES DE MILHO ATRAVÉS DO TESTE DE LIXIVIAÇÃO DE POTÁSSIO
}

\author{
Autor: MARIANE VICTORIO DE CARVALHO MIGUEL \\ Orientador: Prof. Dr. JULIO MARCOS FILHO
}

\section{RESUMO}

A pesquisa teve como objetivo avaliar a eficiência do teste de lixiviação de potássio na determinação do potencial fisiológico de sementes de milho.

Para tanto, foram estudadas diferentes combinações entre volume de água para embebição (75 ml, $50 \mathrm{ml}$ e $25 \mathrm{ml}$ ), número de sementes (100, 50 e 25) e período de embebição $\left(30,60,90,120,150\right.$ e 180 minutos) a $25^{\circ} \mathrm{C}$ e $30^{\circ} \mathrm{C}$. Esses tratamentos foram empregados na avaliação de lotes dos híbridos Avant, AG 6690 e Traktor.

Para efeito de comparação com os resultados obtidos no teste de lixiviação de potássio, os lotes dos três híbridos foram também submetidos aos testes de germinação, primeira contagem de germinação, de envelhecimento acelerado, de frio, de condutividade elétrica e de emergência de plântulas em campo.

De maneira geral, os tratamentos do teste de lixiviação de potássio seguiram a mesma tendência na identificação de diferenças de qualidade entre os lotes, verificadas para os demais testes. A interpretação dos resultados do presente trabalho permitiu concluir que o teste de lixiviação de potássio na combinação de 50 sementes $/ 75 \mathrm{ml}$ de água/90 minutos, a $25^{\circ} \mathrm{C}$, constitui alternativa promissora para detecção de diferenças acentuadas no potencial fisiológico de sementes de milho e que a materialização do seu uso rotineiro 
para avaliação do vigor de sementes de milho depende da evolução da pesquisa rumo à padronização de procedimentos, considerando-se, inclusive, os prováveis efeitos do genótipo. 


\title{
EVALUATION OF MAIZE SEED PHYSIOLOGICAL POTENTIAL BY MEANS OF THE POTASSIUM LEAKAGE TEST
}

\author{
Author: MARIANE VICTORIO DE CARVALHO MIGUEL \\ Adviser: Prof. Dr. JULIO MARCOS FILHO
}

\section{SUMMARY}

The objective of this research was to evaluate different procedures for the potassium leakage test (PLT) as applied to maize seeds. Water volume $(25,50$ and $75 \mathrm{ml})$, number of seeds $(25,50$ and 100$)$ and imbibition periods $(30,60$, $90,120,150$ and 180 minutes) were combined and the test performed at the temperatures of 25 and $30^{\circ} \mathrm{C}$. Those treatment combinations were used to evaluate the physiological quality of seed lots of the hybrids Avant, AG 6690 and Traktor. The results of the PLT were compared to standard germination, germination first count, accelerated aging, cold test, electrical conductivity and field emergence results.

In general, the PLT results followed the same trend displayed by the other tests as to rank the seed lots according to physiological potential. The most promising treatment combination for the PLT was that of 50 seeds $/ 75 \mathrm{ml}$ of water $/ 90$ minutes at $25^{\circ} \mathrm{C}$. This combination showed more accuracy to detect large differences of seed lot quality. The routine use of this test is recognized to be dependent on further research works viewing the standardization of procedures and also considering possible effect of genotypes. 


\section{INTRODUÇÃO}

A análise de sementes constitui etapa fundamental em um sistema de produção de sementes, pois permite conhecer a real qualidade de um lote de sementes e, consequentemente, a tomada de decisões corretas em relação ao seu manejo, principalmente, durante a colheita, processamento e comercialização, permitindo a otimização do sistema produtivo.

Assim, é cada vez maior a necessidade do aprimoramento dos testes que avaliem adequadamente os componentes da qualidade de sementes, dentre eles o potencial fisiológico, principalmente no que diz respeito à rapidez na obtenção de resultados confiáveis.

Existem testes cuja eficiência foi revelada para a determinação da qualidade de sementes de determinadas espécies e menos estudados para outras. Esse é o caso do teste de lixiviação de potássio, que vem se mostrando promissor para sementes de dicotiledôneas, mas ainda praticamente desconhecido para avaliar o desempenho de sementes de gramíneas, onde os testes de envelhecimento acelerado elou de frio têm sido considerados com maior atenção pela pesquisa.

O teste de lixiviação de potássio tem o mesmo princípio do teste de condutividade elétrica, ou seja, se baseia na avaliação indireta do estado de organização das membranas, através da determinação de íons exsudados, no caso o potássio, pelas sementes durante a embebição por período prédeterminado.

A possibilidade do uso desse teste de potássio foi evidenciada após a constatação de que o potássio representa o principal íon liberado durante a 
embebição de sementes, permitindo a obtenção de resultados consistentes em período de tempo reduzido. (Marcos Filho et al., 1982; Queiroga e Parra, 1989; Prete, 1992). Dessa forma, a determinação da perda de compostos específicos pela semente, tem se revelado eficiente para a avaliação do vigor (McDonald, 1998).

A utilização de testes que tenham como características rapidez e confiabilidade se enquadra exatamente nas necessidades do setor de análise de sementes, atendendo as exigências dos produtores e consumidores.

De acordo com o exposto, o presente trabalho foi realizado com o intuito de verificar a eficiência do teste de lixiviação de potássio na avaliação do potencial fisiológico de sementes de milho. 


\section{REVISÃO DE LITERATURA}

\subsection{Deterioração de sementes}

A deterioração da semente é um processo progressivo, inevitável e irreversivel (Carvalho e Nakagawa, 2000) que se manifesta através de alterações físicas, fisiológicas e bioquímicas, com queda gradativa de seu potencial fisiológico, até a paralisação completa do metabolismo ou sua redução a niveis mínimos que não mais permitam a complementação da germinação.

Apesar da deterioração ser um assunto amplamente discutido e estudado, não há consenso a respeito da fisiologia do processo, fato que pode ser atribuído a vários fatores. Para McDonald (1999) são eles:

1. O fato do processo deteriorativo ser variável de acordo com as condições a que as sementes permanecem expostas; as alterações verificadas em sementes deterioradas em campo são diferentes daquelas deterioradas durante o armazenamento;

2. O uso de diferentes métodos para estudar a deterioração, não tem permitido o desenvolvimento de um conceito único;

3. A influência concomitante de fatores ambientais e biológicos, no processo deteriorativo, dificultando a identificação precisa da causa preponderante;

4. O tratamento químico de sementes, que interfere na avaliação da deterioração; 
5. O estudo dos eventos fisiológicos que ocorrem durante a deterioração, considerando as sementes como um todo; tem sido verificado que estes têm início e ocorrem mais rapidamente em determinadas partes da semente;

6. O fato da deterioração ser um evento individual e, a maioria dos estudos, serem conduzidos com amostras de sementes (viáveis e não viáveis), sugerindo-se que os resultados obtidos representam uma população de sementes. No entanto, o processo de deterioração pode apresentar intensidades variáveis entre indivíduos.

O estudo compartimentalizado da deterioração pode ser uma alternativa interessante para que se identifique mais precisamente uma seqüência de eventos e se possa minimizar o processo, uma vez que, este não pode ser evitado.

Para Delouche e Baskin (1973), a seqüência hipotética do processo deteriorativo envolve a degradação das membranas celulares, a redução das atividades respiratórias e biossintéticas, a menor velocidade de na germinação, a redução do potencial de conservação durante o armazenamento, a menor taxa de crescimento e desenvolvimento, a menor uniformidade, a maior sensibilidade às adversidades do ambiente, a redução da emergência das plântulas em campo, o aumento da ocorrência das plântulas anormais e, finalmente, a perda do poder germinativo.

Alguns trabalhos sugerem que a perda de viabilidade das sementes é acompanhada pela redução na capacidade de sintetizar proteínas, em função da perda de eficiência dos ribossomos e alterações nos processos de transcrição e tradução, como conseqüências do processo de deterioração (Cherry e Skadsen, 1983; Aguilar et al., 1991).

A desnaturação de enzimas e a inativação dos ácidos nucléicos e de membranas não funcionais estão ligadas a danos cromossômicos, que podem diminuir a eficiência metabólica de organelas, células e órgãos, devido aos 
aumentos de uso e de mutações somáticas, em conseqüência do envelhecimento (McGee, 1983).

Alterações na respiração das sementes também têm sido apontadas como a causa primária da deterioração, causando modificações na estrutura protéica, inativação enzimática e o aparecimento de mutações (James, 1967). As membranas das mitocôndrias, por serem ricas de lipídios insaturados e, apresentarem cristas, estão sujeitas a intensa peroxidação de lipídios, que interfere nas taxas respiratórias (Wilson e McDonald, 1986).

O efeito da deterioração, sobre a taxa respiratória das sementes, ocasiona atraso na degradação de reservas, prejudicando o desenvolvimento do embrião (Murray, 1984).

Zhang et al. (1994), verificaram que a produção de compostos voláteis pela semente (metabolismo anaeróbico), pode ser um importante fator na aceleração do processo deteriorativo. O acetaldeído teve maior efeito danoso, independentemente, da umidade relativa do ar e da temperatura do ambiente de armazenamento, enquanto, o etanol causou deterioração somente em condições de alta umidade relativa do ar.

Em adição a essas alterações bioquímicas, alterações nas membranas celulares, também estão associadas à deterioração das sementes. Há um decréscimo na permeabilidade das membranas à medida que a semente envelhece (McDonald, 1999).

O mecanismo de degeneração das membranas ocorre com a produção de radicais livres na cadeia de ácidos graxos insaturados na presença de oxigênio (Villiers, 1973). A peroxidação de lipídios afeta consideravelmente a integridade das membranas, exercendo importante papel na deterioração e reduzindo a longevidade de sementes armazenadas sob condições naturais (Khan et al., 1996).

É interessante ressaltar que a deterioração não ocorre de maneira uniforme nas sementes. Anderson (1973), mostrou que os resultados da deterioração dependiam da parte da semente que era considerada, do processo 
que era analisado e das condições às quais as sementes eram submetidas. Em monocotiledôneas, observou-se uma disfunção no escutelo e no eixo embrionário de sementes de milho (Styer e Cantliffe, 1984), enquanto que, em sementes de trigo envelhecidas natural ou artificialmente, o teste de tetrazólio mostrou que o processo tem início na raiz, apesar de haver uma influência do método de envelhecimento (natural ou artificial) no processo deteriorativo (Ganguli e Sen-Mandi, 1990). Em sementes de milho deterioradas, as extremidades das raízes são as primeiras a sofrerem danos (Berjak et al., 1986).

Em dicotiledôneas, através do teste de tetrazólio, verificou-se que as extremidades do eixo embrionário de sementes de soja foram mais sensíveis ao envelhecimento acelerado e os tecidos de reserva, os mais resistentes (Chauhan, 1985).

McDonald (1999), compilou vários trabalhos que estudaram o processo deteriorativo nas sementes e verificou que esse processo causa prejuízos em quase todos os eventos fisiológicos da semente. Assim, a identificação de uma causa comum para a deterioração é um desafio para os pesquisadores.

As sementes sobrevivem em condições de baixa umidade (armazenamento) e alta umidade (embebição). Conseqüentemente, um modelo de deterioração deve considerar os eventos fisiológicos que ocorrem durante 0 armazenamento e a embebição das sementes (McDonald, 1999).

No entanto, a peroxidação de lipídios é, freqüentemente, apontada como a principal causa da deterioração (McDonald, 1999). Considerando-se que os lipídios fazem parte da membrana celular das sementes, há relação direta entre a peroxidação de lipídios e a perda de integridade das membranas.

\subsection{Membranas celulares e queda do potencial fisiológico das sementes}

Os danos causados à membrana pela deterioração, determinando menor seletividade e conseqüente aumento na lixiviação de solutos da semente para o 
meio, tem sido uma das principais causas da queda do potencial fisiológico das sementes.

Os danos à integridade da membrana podem determinar duas conseqüências: a perda da compartimentalização celular ou a deficiência na atividade mitocondrial e a síntese de desidrogenases, transferases e tRNA. Estes dois caminhos conduziriam à perda da viabilidade de sementes (Osborne, 1995).

As membranas celulares se constituem de lipídios, carboidratos e proteínas, sendo as últimas, o principal componente. As proteínas, além de desempenharem um importante papel na estruturação mecânica da membrana, também atuam como transportadoras ou canais de transporte e podem estar relacionadas com propriedades reguladoras ou de reconhecimento(DeRobertis e DeRobertis Jr., 1981). Os lipídios se encontram em uma camada dupla e se associam, interna e externamente, a moléculas de proteínas (Bewley, 1986).

A camada dupla de lipídios age como uma barreira à difusão geral de materiais para o interior e o exterior das células e de organelas, além de providenciar um meio adequado para que as proteínas mensageiras funcionem. Os ácidos graxos constituintes dos lipídios polares são muitos; no tecido vegetal, os mais comuns são os saturados (palmítico e esteárico) e os insaturados (oléico, linoléico e linolênico), conforme relatou (Carvalho, 1994).

$\mathrm{Na}$ membrana plasmática, também se encontram numerosas enzimas, antígenos e diversos tipos de moléculas receptoras como os fitocromos (DeRobertis e DeRobertis Jr., 1981).

A desestruturação das membranas seria conseqüência da ação, em seus componentes, de radicais livres que se formam através da atividade metabólica da célula em função da reação de lipídios estruturais (que compõe a membrana celular), principalmente os polinsaturados, com o oxigênio. Este processo é denominado peroxidação de lipídios e dele resultam radicais livres e peróxidos instáveis (Carvalho, 1994). 
O mecanismo de peroxidação de lipídios freqüentemente se inicia com a presença de oxigênio ao redor dos ácidos graxos insaturados ou polinsaturados, dos quais o oléico e o linoléico são os mais comumente encontrados nas membranas das sementes; o resultado é a formação de radicais livres. Uma vez que se inicia sua formação, os radicais livres aumentam profundamente os danos às membranas e continuam a produzir outros radicais livres, que se combinam com proteínas, enzimas e outras substâncias e determinam reações destrutivas, que causam a perda da integridade da membrana e a redução na proporção dos ácidos graxos insaturados, características de sementes deterioradas (McDonald, 1999).

Os aldeídos voláteis se incluem como produtos da peroxidação de lipídios. Formam-se a partir do ataque de radicais livres a lipídios de armazenamento e constituintes das membranas, causando a degradação dos ácidos graxos de produtos voláteis de carbono de tamanho molecular menor, como hexanal, pentanal e butanal. A presença de aldeídos voláteis identifica indiretamente a ocorrência de peroxidação de lipídios e o aumento da permeabilidade da membrana (Wilson e McDonald, 1986).

Portanto, o processo de envelhecimento consistiria, principalmente, em mudanças dos ácidos graxos insaturados pela ação de radicais livres, resultando em desestruturação da membrana, com reflexos sobre sua capacidade de regular o fluxo de água e de solutos tanto de dentro para fora como no sentido oposto, considerando-se tanto células como suas organelas. A membrana da mitocôndria, por ser muito rica em lipídios insaturados e por apresentar inúmeras dobras (cristas), fato que aumenta o efeito de superfície, é a que apresenta de forma mais intensa a peroxidação de lipídios (Carvalho, 1994).

A organização molecular das membranas é estabilizada em função da relação entre os componentes membranais e a água. Tem sido demonstrado que, quando o grau de hidratação da membrana é inferior a $25 \%$ verifica-se um rearranjo das moléculas da dupla camada de lipídios, formando canais em 
função da organização das cabeças polares dos fosfolipídios que permite a penetração de água e, conseqüentemente, a perda de lixiviados (Bewley e Black, 1994). Este rearranjo foi chamado por Luzzati e Husson (1962) e Stoeckenius (1962) de fase hexagonal, enquanto a fase mais encontrada em seus estudos foi à fase de perfeita organização, a lamelar.

Portanto, as membranas celulares atingem o seu máximo de organização por ocasião da maturidade fisiológica; a partir da aí, a semente começa a perder água e, concomitantemente, há a desorganização das membranas celulares. Durante o processo de germinação ocorre a reidratação das sementes e as membranas se reorganizam. As sementes com menor potencial fisiológico, em decorrência do processo deteriorativo, têm a sua capacidade de reorganização de membranas reduzida, havendo maior perda de solutos para o meio, determinando redução de reservas da semente e prejudicando a uniformidade e a rapidez do processo germinativo.

A embebição é acompanhada pela liberação de açúcares, aminoácidos e íns, em quantidades variáveis de acordo com o estado de organização dos sistemas de membranas celulares (Simon e Raja Harun, 1972; Abdul-Baki e Baker, 1973; Bewley e Black, 1994). As taxas de liberação de solutos e de absorção de água são muito elevadas no início do processo de embebição. Posteriormente, à medida que a membranas se reorganizam, há uma diminuição (Parrish e Leopold, 1977; Abdel Samad e Pearce, 1978; Simon e Mathavan, 1986).

Para Abdul-Baki e Baker (1973), as várias alterações bioquímicas que ocorrem nas sementes quando elas perdem o vigor, podem estar associadas a mudanças nas propriedades das membranas de uma ou mais organelas. Schoettle e Leopold (1984) verificaram que há relação direta entre o aumento da lixiviação de solutos e o aumento de áreas com células danificadas.

A embebição de água por sementes secas envolve paredes celulares e macromoléculas protoplasmáticas, por exemplo, proteínas e polissacarídeos, onde moléculas de água são "presas" por forças eletrostáticas, como ligações 
de hidrogênio. O movimento de água no interior das sementes ocorre devido à difusão e capilaridade, ou seja, do maior para o menor potencial. O potencial mátrico das células da parede e seus componentes são os principais responsáveis pela embebição, que é controlada pela permeabilidade do tegumento da semente (Woodstock, 1988).

Larson (1968) verificou que a remoção do tegumento acelera a embebição, resultando em injúria e perda de solutos, devido à desorganização da membrana, que determina redução no crescimento de plântulas.

Matthews e Rogerson (1976), trabalhando com diferentes lotes de sementes de ervilha, concluíram que a lixiviação de solutos estava relacionada com a condição do embrião e não à condição da testa. A diferenciação entre lotes ocorreu por diferenças no padrão de lixiviação de tecidos vivos.

A liberação de solutos durante a embebição é conseqüência da difusão passiva de solutos de baixo peso molecular e da lixiviação de macromoléculas por ruptura celular (Duke et al., 1983). Powell et al. (1986) mostraram evidências de danos durante a embebição de sementes de feijão, com a morte de tecidos e aumento na lixiviação de solutos. As membranas de sementes sensiveis à desidratação foram afetadas quando as sementes estavam com teor de água inferior a um nível crítico, que depende da espécie (Becwar et al., 1982).

Powell e Matthews (1981), verificaram que sementes de ervilha, nos estágios iniciais de deterioração, foram incapazes de reter solutos. Esse fato está associado com a queda no conteúdo total de fosfolipídios e com variações em fosfolipídios específicos.

Lin (1988), trabalhando com sementes de milho, concluiu que, durante o armazenamento, o teor de água das sementes aumentou, ocasionando a deterioração da membrana plasmática e conseqüente queda no vigor e germinação, avaliados pelo aumento da lixiviação de eletrólitos. 


\subsection{Testes de vigor baseados na permeabilidade de membranas}

O objetivo da determinação do potencial fisiológico das sementes é encontrar uma relação entre o nível identificado e o desempenho das sementes em condições naturais de germinação. Essa determinação é feita através de testes de laboratório que procuram simular condições de estresse que desencadeiam o processo de deterioração como umidade relativa do ar e temperatura elevadas (teste de envelhecimento acelerado) ou alta umidade do solo e baixa temperatura (teste de frio).

Uma outra alternativa é o uso de testes que avaliem o estado metabólico atual das sementes, não sendo provocada nenhuma alteração física ou fisiológica nas mesmas. Esses testes são desenvolvidos a partir do estudo de eventos que ocorrem durante a deterioração nas sementes e que possam ser indicativos da quantificação da perda do seu potencial fisiológico, como por exemplo, os testes de condutividade elétrica e lixiviação de potássio.

O teste de condutividade elétrica tem como princípio avaliar indiretamente o grau de desestruturação das membranas celulares, em decorrência da deterioração das sementes, através da determinação da quantidade de íons lixiviados em uma solução com determinado volume de água destilada, onde um número conhecido de sementes é embebido sob temperatura controlada, durante período pré-estabelecido. As sementes de menor potencial fisiológico liberam quantidade maior de lixiviados, como conseqüência da menor seletividade das membranas.

Várias pesquisas demonstram que o decréscimo do potencial fisiológico e da germinação das sementes têm relação direta com o aumento da lixiviação de solutos, como conseqüência da perda da integridade das membranas. Dentre os trabalhos dedicados ao assunto, destacam-se os realizados por Schoettle e Leopold (1984), com soja, Gorecki et al. (1985), com ervilha, Marcos Filho et al. (1985 e 1990) e Loeffler et al. (1988) com soja; Woodstock et 
al. (1985), Fraga (1988), Brigante (1988) e Santos (1993) com algodão; Bruggink et al. (1991), com milho.

Baseado no mesmo princípio, o teste de lixiviação de potássio tem merecido especial atenção, por apresentar vantagens em relação ao de condutividade elétrica, como a avaliação de um íon específico, como maior rapidez na determinação e obtenção de resultados confiáveis, em decorrência da avaliação de um íon específico. Dias e Marcos Filho (1995) afirmaram que um dos requisitos básicos para a avaliação do vigor das sementes refere-se à obtenção de resultados confiáveis em um período de tempo relativamente curto, uma vez que as tomadas de decisões devem ser agilizadas, principalmente quanto às operações de colheita, processamento e comercialização.

Quando as sementes são colocadas para embeber, parte significativa dos eletrólitos é representada por vários íons inorgânicos; nesse sentido, alguns estudos vêm sendo realizados com o objetivo de determinar a liberação de cátions específicos pelas sementes, durante esse período (Dias e Marcos Filho, 1995). Trabalhos como os de Marcos Filho et al. (1982), Queiroga e Parra (1989) e Prete (1992), demonstraram que grande parte da condutividade elétrica se deve à lixiviação de íons potássio. Para McDonald (1998) a detecção de perdas de compostos específicos, pela semente, pode ser promissora na avaliação do vigor.

Abdel Samad e Pearce (1978) constataram rápida lixiviação de potássio e outros compostos na primeira hora de embebição de sementes de amendoim. Loomis e Smith (1980) observaram perdas de cálcio, magnésio, manganês, potássio e cloro, durante a embebição de sementes de repolho envelhecidas artificialmente. Outros estudos determinaram a quantidade de potássio e sódio liberados (McKersie e Stinson, 1980). Granqvist (1987) observou, principalmente, a liberação de potássio em sementes de cenoura.

Em exsudados de sementes de soja, após 90 minutos de imersão em água deionizada à $28^{\circ} \mathrm{C}$, Oliveira (1990) quantificou a presença de cálcio, magnésio, sódio e potássio. 
Lott et al. (1991) verificou o total de íons de potássio, magnésio, cloro, cálcio e manganês na água de embebição de sementes intactas ou em partes isoladas destas, em soja e ervilha; os resultados mostraram que o potássio foi, geralmente, o elemento liberado em maior quantidade, enquanto que 0 manganês foi o menos lixiviado.

Givelberg et al. (1984) verificaram que a perda de potássio, cálcio, sódio e magnésio em sementes de sorgo ocorreu durante as primeiras horas de embebição, principalmente entre três e seis horas; a partir de então houve decréscimo acentuado.

Portanto, vários trabalhos indicaram que a quantidade de potássio lixiviado pelas sementes durante a embebição pode constituir um referencial da perda do potencial fisiológico. Entre estes, pode-se citar os de Halloin (1975), McKersie e Stinson (1980), Woodstock et al. (1985), Weges e Karssen (1990), Dias et al. (1996) e Custódio e Marcos Filho (1997). Wood (1990), associou a perda de potássio aos danos à membrana, em um trabalho para determinação de perdas de minerais em plântulas de soja, girassol e sorgo.

Marcos Filho et al. (1982) estudando as relações entre germinação, vigor e permeabilidade das membranas celulares durante a maturação de sementes, encontraram índices de correlação negativos e altamente significativos entre os dados de lixiviação de potássio e os de germinação, de primeira contagem de germinação e de envelhecimento acelerado. Considerando-se que os testes de vigor fornecem índices mais sensiveis do potencial fisiológico, quando comparados ao teste de padrão de germinação (AOSA, 1983), qualquer evento que preceda a perda do poder germinativo pode servir como base para 0 desenvolvimento de testes de vigor.

Entretanto, acredita-se, que quanto mais próximo da maturidade fisiológica estiver o parâmetro avaliado, mais sensivel será o teste. Assim, como a degradação das membranas celulares se constitui, hipoteticamente, no primeiro evento do processo de deterioração (Delouche e Baskin, 1973), os 
testes que avaliam a integridade das membranas seriam, teoricamente, os mais sensiveis para estimar o vigor (Marcos Filho, 1999a).

Marcos Filho et al. (1982), verificaram que sementes colhidas em épocas subseqüentes à maturidade, exibiram acréscimos na taxa de lixiviação de potássio e reduções da qualidade; a determinação do potássio liberado pelas sementes foi realizada após 90 minutos de embebição.

Dias et al. (1996) verificaram que a quantidade de potássio lixiviado, em sementes de soja, permitiu a identificação de lotes com diferentes níveis de vigor e potencial de emergência de plântulas em campo, revelando a sua importância para a dinamização dos programas de controle de qualidade destas sementes.

Em sementes de girassol, Queiroga e Parra (1989) constataram que o elemento inorgânico que mais contribuiu (95\%) para o aumento da condutividade elétrica da solução de embebição foi o potássio, enquanto que as lixiviações de sódio e de cálcio foram, respectivamente, 10 e 100 vezes menores que a de potássio. Lee e Karunanithy (1990) observaram que, durante a germinação de sementes de feijão e soja, as perdas de potássio são maiores que as de cálcio, ferro e magnésio, provavelmente devido à habilidade de formarem complexos com proteínas e ácido fítico.

Woodstock et al. (1985) constataram, através da microscopia eletrônica, a deterioração de membranas de sementes de algodão e ressaltaram que as lixiviações de minerais individuais, como potássio e cálcio, foram melhores indicadores da qualidade de sementes do que métodos que avaliam a liberação de um conjunto de íons, como a condutividade elétrica.

Os resultados do teste de lixiviação de potássio podem ser influenciados por vários fatores como: tamanho das sementes, número de sementes embebidas, temperatura de embebição e volume de água de embebição, que acabam por dificultar sua padronização. Para AOSA (1983), os principais problemas encontrados para a padronização de testes de vigor são quatro: 1) precisão dos procedimentos dos testes; 2) padronização dos procedimentos; 3 ) 
apresentação dos resultados e, 4) estabelecimento de níveis de vigor aceitáveis.

Simon e Mathavan (1986) verificaram que quanto menor a semente, mais rápida é a embebição e a lixiviação de potássio. Em sementes pequenas, a lixiviação pode ocorrer em um período inferior a duas horas de embebição (Murphy e Noland, 1982), enquanto que, em sementes maiores, como soja, verificou-se aumento de lixiviação até 24-30 horas após o início da embebição, a $25^{\circ} \mathrm{C}$ (Loeffler et al., 1988).

Em contrapartida, Queiroga e Parra (1989) ressaltaram a influência do peso da semente sobre a quantidade de potássio lixiviado, mostrando que as mais pesadas apresentam valores mais altos deste elemento. A interferência desta variável pode ser solucionada com a pesagem das amostras.

Outro fator destacado na literatura é a temperatura de embebição, refletindo-se na velocidade de embebição e de lixiviação de eletrólitos do interior das células para o meio externo (Leopold, 1980). O efeito da temperatura sobre a lixiviação se manifesta, basicamente, sobre a quantidade e velocidade de perda de lixiviados, sem alterar, entretanto, a classificação dos lotes (Hampton, 1995).

Sob temperaturas baixas, o processo de reorganização de membranas é mais lento e aumenta o período de perda de lixiviados pelas sementes; em altas temperaturas, há dano térmico às membranas, causando aumento na lixiviação (Givelberg, et al., 1984). Portanto, a escolha da temperatura adequada é fundamental para que a avaliação do potencial fisiológico das sementes seja correta.

Em pesquisas iniciais, Amorim (1978) e Marcos Filho (1979) obtiveram resultados interessantes com o teste de lixiviação de potássio, trabalhando com temperatura ambiente. Pesquisas posteriores optaram por controlar a temperatura durante a embebição das sementes, contribuindo para menor variação dos resultados. 
Marcos Filho et al (1982), trabalhando com temperatura de $30^{\circ} \mathrm{C}$ verificaram uma relação inversa entre a lixiviação de potássio e o poder germinativo e o vigor de sementes de soja, durante o processo de maturação. Esses resultados foram confirmados por Dias et al. (1996) e Custódio e Marcos Filho (1997).

Doni Filho (1992), verificou que a temperatura de $20^{\circ} \mathrm{C}$ foi adequada, durante a condução do teste de lixiviação de potássio para verificar os efeitos do condicionamento fisiológico em sementes de feijão. Prete (1992), utilizando as temperaturas de 20 e $25^{\circ} \mathrm{C}$, considerou que, para a avaliação da qualidade da bebida do café através da lixiviação de potássio, a de $25^{\circ} \mathrm{C}$ foi mais eficiente.

A perda de potássio foi significativamente afetada pela alta temperatura. Durante as três primeiras horas de embebição a lixiviação de potássio foi duas vezes mais rápida a $50^{\circ} \mathrm{C}$ do que a $25^{\circ} \mathrm{C}$ (Givelberg, et al., 1984).

Além da temperatura de embebição, a temperatura de avaliação tem efeito direto e significativo sobre os resultados da condutividade elétrica. Assim, Loeffler et al. (1988), com sementes de soja, demonstraram que aumentos ou reduções de $5^{\circ} \mathrm{C}$ na temperatura de avaliação proporcionaram alterações significativas nos resultados. Assim, o número de amostras retiradas da câmara $\left(25^{\circ} \mathrm{C}\right)$ deve ser suficiente para que a avaliação possa ser realizada, no máximo, em 15 minutos.

O período de embebição é outro fator muito importante. A sua escolha deve considerar um tempo necessário para que as sementes lixiviem uma quantidade de potássio que permita a diferenciação dos lotes, de acordo com seus potenciais fisiológicos.

Amorim (1978) verificou melhores diferenças entre os tratamentos, trabalhando com 90 minutos, quando o objetivo foi verificar a relação da qualidade da bebida do café com a lixiviação de potássio. Já Prete (1992), com o objetivo de avaliar a relação da bebida do café com a condutividade elétrica do exsudato e lixiviação de potássio, verificou ser de três horas e meia o melhor tempo para a condutividade elétrica e de três horas para a lixiviação de 
potássio. Portanto, a escolha do período de tempo para a realização da leitura de lixiviação de potássio deve estar relacionada com o objetivo em questão.

Marcos Filho (1979) e Marcos Filho et al. (1982), obtiveram bons resultados na avaliação do potencial fisiológico de sementes de soja, com leituras de lixiviação aos 90 minutos de embebição. Dias e Marcos Filho (1996) estudaram o uso de 60, 90, 120 e 150 minutos, na avaliação do vigor de sementes de soja e, constataram que 90 minutos foi o mais adequado. Custódio e Marcos Filho (1997), em estudo semelhante encontraram o tempo de 30 minutos como o ideal, para a separação de lotes de soja, quanto ao potencial fisiológico.

Há evidências de que as diferenças de lixiviação de potássio aparecem nos primeiros minutos após a embebição (Matthews e Rogerson, 1976; Sreeramulu, 1983). Esse aspecto é relevante, em decorrência do interesse em respostas rápidas na distinção da qualidade de lotes de sementes.

Quanto à quantidade de água e número de sementes. Devem ser feitas combinações que possibilitem a leitura direta de lixiviação de potássio sem que seja necessário trabalhar com diluição, pois o tempo adicional despendido nessa operação contribuiria para reduzir uma das principais vantagens do teste, ou seja, a rapidez na obtenção dos resultados. Além disso, a diluição das amostras se constitui em fator adicional para dificultar a padronização do teste.

As variáveis quantidades de água e número de sementes apresentam-se interdependentes, pois estão diretamente relacionadas com a concentração da solução que será submetida à leitura e do método utilizado para a leitura. Custódio e Marcos Filho (1997), verificaram que uma avaliação adequada da qualidade de semente de soja foi possível através da combinação de 25 sementes com 75 ou $100 \mathrm{ml}$ de água.

Quanto ao método utilizado, a maioria dos autores tem realizado a leitura de potássio lixiviado através do fotômetro de chama (Simon e Raja Harun, 1972; Sreeramulu, 1983; Givelberg et al., 1984; Queiroga e Parra, 1989; Pandey, 1989; Weges e Karssen, 1990); outros, porém utilizaram o 
espectrofotômetro de absorção atômica (Matthews e Rogerson, 1976; Moss e Mullett, 1982; Granqvist, 1987; Wood, 1990) e outros ainda, análise de ativação de nêutrons (Loomis e Smith, 1980; Lott et al., 1991), cuja metodologia é mais complexa. De acordo com Rodela e Borges (1989) a fotometria de chamas é o único método viável para a determinação de potássio nas análises de rotina, devido principalmente a maior precisão, menor custo e maior simplicidade.

Nota-se que há vários trabalhos com o teste de lixiviação de potássio; no entanto, existe carência de informações para sementes de gramíneas, onde testes de envelhecimento acelerado e/ou de frio têm sido considerados com maior atenção pela pesquisa. 


\section{MATERIAL E MÉTODOS}

A pesquisa foi realizada no Laboratório de Análise de Sementes (LAS), do Departamento de Produção Vegetal, Escola Superior de Agricultura "Luiz de Queiroz" (LPV/ESALQ), Universidade de São Paulo (USP), durante os anos de 1999 e 2000.

Foram analisadas sementes de três híbridos de milho, sendo dois simples (Avant e AG 6690) e um duplo (Traktor). Os híbridos Avant e Traktor foram representados por 5 lotes, enquanto o AG 6690 por 4 lotes; desta forma, foram analisados 14 lotes de sementes.

As sementes de "Avant" e "Traktor" foram classificadas com o uso de uma seqüência de peneiras de crivos oblongos, aproveitando-se as retidas em peneiras com perfurações de $20 \times 3 / 4$ ". O mesmo procedimento foi adotado para o híbrido" AG 6690 "; no entanto, aproveitaram-se as sementes retidas em peneiras com perfurações 20/64" As sementes não foram tratadas com produtos químicos.

\subsection{Avaliações preliminares}

Os lotes foram, inicialmente, submetidos a avaliações do teor de água germinação, primeira contagem de germinação, envelhecimento acelerado, teste de frio, condutividade elétrica e emergência de plântulas em campo, com o objetivo de avaliar o potencial fisiológico inicial das sementes e para que, posteriormente, as informações obtidas nesses testes fossem comparadas com 
as proporcionadas pelos diferentes tratamentos estudados para o teste de lixiviação de potássio.

Teor de água das sementes: determinado em estufa a $105 \pm 3^{\circ} \mathrm{C}$, durante 24 horas, utilizando-se duas amostras para cada lote, segundo as instruções das Regras para Análise de Sementes (Brasil, 1992); os resultados foram expressos em porcentagem (base úmida).

Germinação: utilizaram-se quatro amostras de 50 sementes por lote, distribuídas em rolos de papel toalha Germitest, umedecidos com quantidade de água equivalente a 2,5 vezes o peso do substrato seco, colocadas para germinar a $25^{\circ} \mathrm{C}$. As avaliações foram realizadas aos quatro e sete dias após a semeadura, segundo os critérios estabelecidos pelas Regras para Análise de Sementes (Brasil, 1992), com os resultados expressos em porcentagem média de plântulas normais, para cada lote.

Primeira contagem de germinação: conduzida juntamente com o teste de germinação, registrando-se a porcentagem média de plântulas normais, aos quatro dias após a semeadura.

Envelhecimento acelerado: adotou-se a metodologia recomendada pelo Comitê de Vigor da Association of Official Seed Analysts/AOSA (1983), descrita por Marcos Filho (1999b). As sementes foram colocadas, em camada única, sobre telas de alumínio mantidas no interior de caixas plásticas tipo "gerbox" (mini-câmara), contendo $40 \mathrm{ml}$ de água, a $41^{\circ} \mathrm{C}$ por 96 horas, em câmara B.O.D.. Decorrido este período, quatro amostras de 50 sementes por lote foram colocadas para germinar, conforme descrito anteriormente para o teste de germinação. A avaliação foi realizada aos quatro dias após a semeadura, computando-se a porcentagem média de plântulas normais para cada lote. Foi determinado, também, o grau de umidade das sementes após o 
envelhecimento, visando avaliar a uniformidade das condições predominantes durante a condução do teste.

Teste de frio: conduzido com quatro repetições de 50 sementes, por lote de cada híbrido, distribuídas em caixas plásticas $(60 \times 30 \times 10 \mathrm{~cm})$, contendo uma mistura nas proporções, em peso, de $2 / 3$ de areia e $1 / 3$ de solo previamente cultivado com milho. Após a semeadura, foi adicionada água ao substrato até que o mesmo atingisse $60 \%$ da capacidade de retenção. As caixas foram mantidas a $10^{\circ} \mathrm{C}$ por 7 dias e, posteriormente, mantidas em condições normais de ambiente por igual período. Os resultados foram expressos em porcentagem média de plântulas normais para cada lote (Marcos Filho, et al., 1987).

Condutividade elétrica: utilizaram-se quatro repetições de 50 sementes, para cada lote de cada híbrido, pesadas com precisão de $0,01 \mathrm{~g}$ e colocadas em copos plásticos (capacidade de $200 \mathrm{ml}$ ) contendo $75 \mathrm{ml}$ de água destilada, a $25^{\circ} \mathrm{C}$. As leituras da condutividade elétrica foram efetuadas, após 24 horas de embebição, em condutivímetro DIGIMED CD-20; os valores médios obtidos para cada lote foram expressos em $\mu \mathrm{mho} / \mathrm{cm} / \mathrm{g}$ de semente.

Emergência de plântulas em campo: conduzida em área experimental do LPV/ USP/ESALQ, com quatro amostras de 100 sementes para cada lote de cada híbrido. O solo foi mantido com umidade suficiente, através de irrigações, para permitir o desenvolvimento adequado das plântulas. A semeadura foi realizada em profundidade de $3-4 \mathrm{~cm}$ e as sementes foram cobertas com uma camada de, aproximadamente, $1 \mathrm{~cm}$ de terra; a avaliação das plântulas emergidas foi feita 15 dias após a semeadura e, os resultados expressos em porcentagem média de plântulas emergidas. 


\subsection{Lixiviação de potássio}

\subsubsection{Preparo das amostras}

Sementes fisicamente puras foram contadas manualmente (sem escolha), pesadas e, posteriormente, colocadas no interior de copos plásticos com capacidade para $200 \mathrm{ml}$, contendo quantidades pré-determinadas de água destilada e, mantidas em câmara B.O.D. a $25^{\circ} \mathrm{C}$ ou $30^{\circ} \mathrm{C}$, até o momento da leitura de lixiviação de potássio. Foram utilizadas quatro repetições para cada tratamento.

\subsubsection{Leituras da lixiviação de potássio}

As leituras foram efetuadas em fotômetro de chama DIGIMED NK-2020, utilizando-se o padrão 50 ppm de potássio, ajustado para leitura 50. Escolheuse este padrão, porque proporcionou a realização de um maior número de leituras sem a necessidade de diluição, para as sementes de milho, dentro dos períodos estudados (Carvalho et al., 1999).

Inicialmente, foi estabelecida uma curva de calibração através de regressão linear, para verificar a linearidade da curva da solução padrão de 50 ppm de potássio. Foram preparados padrões de $50,45,40,35,30,25,20,15$, 10 e 5 ppm de potássio. $O$ fotômetro de chama foi calibrado com o padrão de 50ppm de potássio e, então, foram feitas as leituras dos outros padrões.

Os copos plásticos com os diferentes tratamentos foram mantidos em B.O.D., até o momento da leitura da lixiviação de potássio. Para cada tratamento, foram feitas leituras de 30 em 30 minutos até completar 180 minutos de embebição, devido ao padrão de liberação das sementes de milho observado em curvas estabelecidas por 24 horas (Carvalho et al., 1999). Os resultados foram expressos em ppm $\mathrm{Kg}$ de semente. 


\subsubsection{Cálculo da quantidade de potássio exsudado pelas sementes}

O cálculo da lixiviação de potássio foi feito pela multiplicação da leitura obtida no fotômetro de chama $(\mathrm{K} / \mathrm{ml})$ pelo volume de água destilada ( $\mathrm{ml}$ ) e dividido pelo peso da amostra (g). O resultado final foi expresso em ppm K/g de semente.

As leituras da quantidade de potássio exsudados pelas sementes de milho, nos diferentes períodos de embebição, foram feitas no mesmo material; portanto, para fazer os cálculos descontou-se $1 \mathrm{ml}$, do volume da solução, a cada leitura, porque o fotômetro de chama utiliza $1 \mathrm{ml}$ de solução para determinar a quantidade de potássio lixiviado, segundo as informações técnicas do aparelho.

\subsubsection{Teste de lixiviação de potássio}

A verificação da eficiência dos diferentes tratamentos, para o teste de lixiviação de potássio, na avaliação do potencial fisiológico de sementes de milho foi realizada em duas épocas consecutivas(E1 e E2), para evitar que a deterioração das sementes influísse nos resultados. Essas avaliações tiveram o objetivo de confirmar os resultados da época 1 na época 2.

A avaliação feita em cada época consistiu na tentativa de identificação do tratamento mais eficiente para separar os lotes de cada híbrido, de acordo com o potencial fisiológico das sementes. Foram estudadas variações no período de embebição, no número de sementes, no volume de embebição, nas temperaturas de $25^{\circ} \mathrm{C}$ e $30^{\circ} \mathrm{C}$, para os lotes de cada híbrido. Desta forma, os tratamentos foram os seguintes:

1. 100 sementes embebidas em $75 \mathrm{ml}$ de água destilada;

2. 100 sementes embebidas em $50 \mathrm{ml}$ de água destilada;

3. 50 sementes embebidas em $75 \mathrm{ml}$ de água destilada; 
4. 50 sementes embebidas em $50 \mathrm{ml}$ de água destilada;

5. 50 sementes embebidas em $25 \mathrm{ml}$ de água destilada;

6. 25 sementes embebidas em $75 \mathrm{ml}$ de água destilada;

7. 25 sementes embebidas em $50 \mathrm{ml}$ de água destilada;

8. 25 sementes embebidas em $25 \mathrm{ml}$ de água destilada;

As leituras de lixiviação de potássio foram feitas a cada 30 minutos até um total de 180 minutos de embebição. Para efeito de comparação entre os tratamentos, a análise dos dados foi feita dentro de cada período de embebição, fixando-se a temperatura de $25^{\circ} \mathrm{C}$ ou de $30^{\circ} \mathrm{C}$, para verificar qual a melhor combinação entre o número de sementes e o volume de água, para cada híbrido.

O ranqueamento dos lotes, de cada híbrido, correspondente ao teste de lixiviação de potássio foi comparado com os obtidos nos outros testes utilizados, nesta pesquisa, para avaliação do potencial fisiológico de sementes de milho (germinação, primeira contagem de germinação, envelhecimento acelerado, teste de frio, condutividade elétrica e emergência de plântulas em campo), para verificar a compatibilidade das informações oferecidas pelos diferentes testes de vigor conduzidos.

\subsection{Análise da composição química das sementes e da solução de embebição}

As análises foram efetuadas com o objetivo de verificar se os teores de potássio das sementes se associaram às quantidades exsudadas, ou seja, determinar até que ponto os resultados eram determinados pelo grau de estruturação das membranas celulares.

Foram realizadas pelo Departamento de Química da Escola Superior de Agricultura "Luiz de Queiroz". Utilizaram-se $50 \mathrm{~g}$ de sementes por lote e $20 \mathrm{ml}$ da solução de embebição e de água destilada (testemunha), segundo o método analítico descrito por Sarruge e Haag (1974). 


\subsection{Procedimento estatístico}

Os dados provenientes dos testes de germinação, de primeira contagem de germinação, de envelhecimento acelerado, de frio e de emergência em campo, foram transformados em $\sqrt{x / 100}$, enquanto que os resultados de condutividade elétrica e lixiviação de potássio não sofreram transformações.

Os resultados das determinações do teor de água das sementes antes e após o teste de envelhecimento acelerado não foram analisados estatisticamente; suas interpretações foram relacionadas apenas aos aspectos biológicos.

A análise dos dados de lixiviação de potássio foi realizada sob delineamento inteiramente casualizado em esquema fatorial $8 \times 5$ ou $8 \times 4$ que variou em função do número de lotes como se observa na Tabela 1. Para a análise dos testes padrão de germinação, primeira contagem de germinação, envelhecimento acelerado, frio, emergência de plântulas em campo e condutividade elétrica, o delineamento, também, foi o inteiramente casualizado com 4 ou 5 lotes, dependendo do híbrido. Os esquemas da análise da variância estão na Tabela 2.

Para comparação múltipla de médias utilizou-se o teste de Tukey com $5 \%$ de probabilidade. Os cálculos estatísticos foram realizados através do Sistema de Análise Estatística - SANEST (Zonta et al., 1984). 
Tabela 1. Esquema da análise da variância dos dados de lixiviação de potássio, para cada híbrido.

\begin{tabular}{lcc}
\hline \multicolumn{1}{c}{ Causas de variação } & $\begin{array}{c}\text { Graus de liberdade } \\
\text { (Avant, Traktor) }\end{array}$ & $\begin{array}{c}\text { Graus de liberdade } \\
\text { (AG 6690) }\end{array}$ \\
\hline Tratamentos & 7 & 7 \\
Lotes & 4 & 3 \\
Tratamentos x Lotes & 28 & 21 \\
Resíduo & 120 & 96 \\
Total & 159 & 127 \\
\hline \hline
\end{tabular}

Tabela 2. Esquema da análise de variância dos dados de germinação, primeira contagem de germinação, envelhecimento acelerado, teste de frio, emergência em campo e condutividade elétrica para cada híbrido.

\begin{tabular}{lcc}
\hline Causas de variação & $\begin{array}{c}\text { Graus de liberdade (Avant, } \\
\text { Traktor) }\end{array}$ & $\begin{array}{c}\text { Graus de liberdade } \\
\text { (AG 6690) }\end{array}$ \\
\hline Lotes & 4 & 3 \\
Resíduo & 15 & 12 \\
Total & 19 & 15 \\
\hline
\end{tabular}




\section{RESULTADOS E DISCUSSÃO}

\subsection{Calibração do fotômetro de chama}

A calibração do fotômetro de chama constitui etapa fundamental para a obtenção de resultados consistentes durante a condução do teste de lixiviação de potássio (Custódio et al., 1997). Após a realização de observações preliminares, optou-se pelo uso da solução padrão de 50 ppm de potássio (Carvalho et al., 1999). É interessante ressaltar que a utilização desse padrão permitiu que um maior número de leituras de lixiviação fossem realizadas sem a necessidade de diluição das amostras de sementes de milho.

Padrões de ajustes mais diluídos (concentrações menores que 50 ppm) provocariam a necessidade da diluição de um maior número de amostras, o que determinaria redução de vantagens adicionais do teste, como rapidez e praticidade (Rodela e Borges, 1989), reduzindo a viabilidade de seu uso como rotina em laboratórios de análise de qualidade de sementes.

Além das vantagens, já mencionadas, o padrão de 50 ppm de potássio deve fornecer dados confiáveis, ou seja, a quantidade de potássio determinada na solução de embebição de sementes pelo fotômetro de chama, calibrado com o referido padrão, deve ser precisa. Essa confiabilidade é determinada através de regressão linear.

A curva de calibração da solução padrão de 50 ppm de potássio (Figura 1), estabelecida através de regressão linear, apresentou coeficiente de determinação de 0,985 , indicando que os valores de lixiviação de potássio 
observados foram muito próximos dos estimados, verificando-se, portanto, alta confiabilidade nos resultados fornecidos pelo fotômetro de chama.

Assim, pode-se considerar que o uso do padrão de 50 ppm de potássio permitiu que o teste de lixiviação de potássio mantivesse suas características principais: praticidade, rapidez e confiabilidade dos resultados. Dessa forma, uma possível ineficiência do teste não poderia ser atribuída ao método de quantificação de potássio.

Figura 1. Representação gráfica da curva de calibração do fotômetro de chama, utilizando-se solução padrão de 50 ppm de potássio.

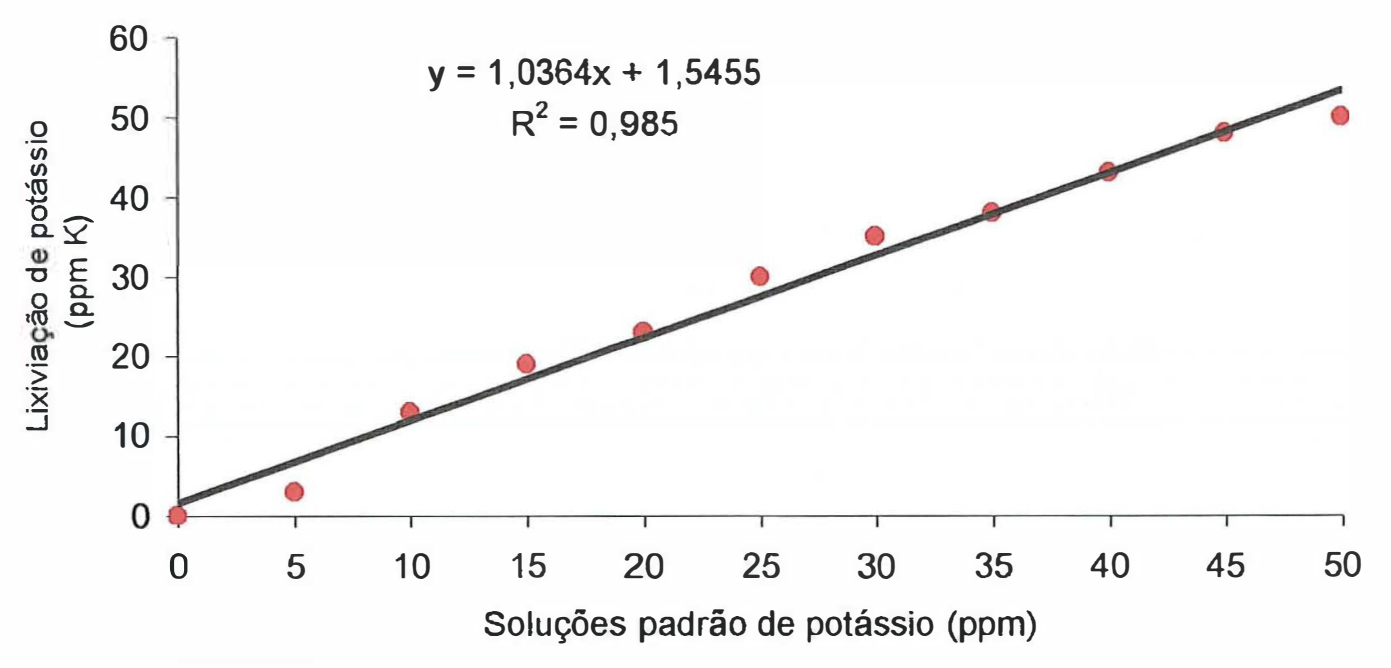

- Observados Estimados 


\subsection{Avaliações preliminares do potencial fisiológico dos lotes}

Os dados das avaliações preliminares do potencial fisiológico dos lotes dos híbridos Avant, AG 6690 e Traktor, foram apresentados na forma de Figuras. A comparação entre as médias foi feita dentro de cada linha, de modo que cada letra ou grupo de letras indica a significância referente aos contrastes entre lotes dentro de cada teste.

\subsubsection{Híbrido Avant}

Os resultados referentes às avaliações preliminares estão na Figura 2.

No teste de germinação os lotes 1 e 4 foram superiores e diferiram estatisticamente dos lotes 3 e 5, que apresentaram potencial fisiológico inferior. O lote 2 apresentou comportamento intermediário, em relação aos demais. A classificação dos lotes pelos testes de primeira contagem de germinação e de frio foi semelhante à do teste padrão de germinação.

$\mathrm{Na}$ emergência de plântulas em campo e na condutividade elétrica, os lotes 1 e 4 também foram classificados como superiores, diferindo estatisticamente dos lotes 2,3 , e 5 .

De acordo com o teste de envelhecimento acelerado o lote de melhor desempenho fisiológico foi o 1 , diferindo estatisticamente do lote 3 , o de pior desempenho. O lote 4 apresentou desempenho intermediário, não diferindo do lote 1 e dos lotes 2 e 5 e estes não diferiram do lote 3 . Esse teste foi mais sensivel na deteç̧ão de níveis de qualidade entre os lotes, quando comparado com os outros testes de vigor utilizados na avaliação inicial do potencial fisiológico dos lotes. 
Figura 2. Híbrido Avant: Resultados da avaliação do potencial fisiológico dos cinco lotes de sementes, através dos testes de germinação (Germ. - \%), primeira contagem de germinação (1aㅡ cont. - \%), envelhecimento acelerado (EA - \%), teste de frio (TF - \%), emergência de plântulas em campo (EPC - \%) e condutividade elétrica (CE $\mu \mathrm{mho} / \mathrm{cm} / \mathrm{g}$ de semente).

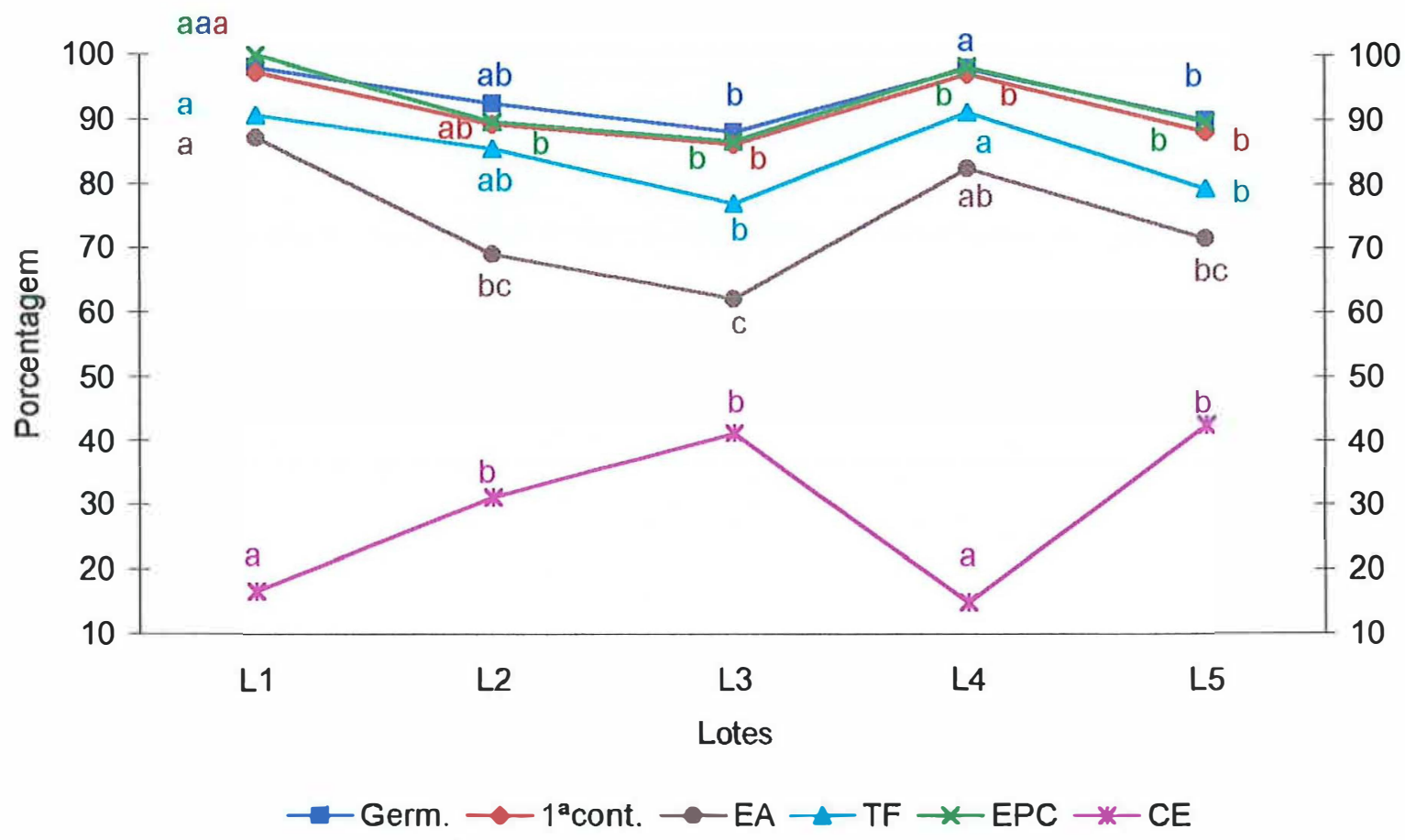

Observou-se que, em geral, os testes classificaram os lotes da mesma maneira e que houve eficiência consistente na deteç̧ão do lote 1 como superior e do lote 3 como inferior, de acordo com o desempenho da germinação e do vigor dos lotes.

Entretanto, os lotes 2, 4 e 5 foram classificados de maneiras distintas, em função do teste utilizado. Assim, o lote 4, que ocupou posição superior nos testes de primeira contagem de germinação, de frio, de emergência de plântulas em campo e de condutividade elétrica, foi identificado como de vigor intermediário pelo teste de envelhecimento acelerado. Ao mesmo tempo, o lote 
2 ocupou posição inferior nos testes de emergência de plântulas em campo e condutividade elétrica e posição intermediária nos testes de primeira contagem de germinação, de frio e de envelhecimento acelerado. $O$ lote 5 foi classificado de forma semelhante ao lote 2 , com exceção dos testes de primeira contagem de germinação e de frio, onde foi apontado como de qualidade inferior.

Diante das informações obtidas, fica nítido que, em geral, os testes foram eficientes na identificação dos lotes que ocupam posições extremas, em relação aos demais, ou seja, os testes separaram de maneira consistente as diferenças acentuadas no potencial fisiológico das sementes. Assim, pode-se afirmar, com segurança, que o lote 1 foi significativamente mais vigoroso que o lote 3 e que os demais lotes apresentaram qualidade intermediária, ocupando posições diferentes de acordo com o teste utilizado.

\subsubsection{Híbrido AG 6690}

Os resultados das avaliações preliminares do potencial fisiológico dos lotes do híbrido AG 6690 estão na Figura 3.

De acordo com os resultados do teste de germinação, os lotes 1 e 2 atingiram o máximo de suas capacidades germinativas e os lotes 3 e 4 foram estatisticamente inferiores.

No teste de envelhecimento acelerado, o lote 2 foi apontado como de maior potencial fisiológico, enquanto que o lote 4 como o de menor. Os lotes 1 e 3 apresentaram comportamento intermediário.

Os testes de primeira contagem de germinação, de frio e de emergência de plântulas em campo identificaram os lotes 1 e 2 como superiores e os lotes 3 e 4 como inferiores, ou seja, de maneira semelhante ao teste de germinação.

$O$ teste de condutividade elétrica foi o mais sensível na detecção de diferenças entre a qualidade dos lotes. $O$ lote 2 foi estatisticamente superior ao 
lote 4; os lotes 1 e 3 apresentaram comportamento intermediário e diferiram estatisticamente dos lote 2 e 4.

Figura 3. Híbrido AG 6690: resultados da avaliação do potencial fisiológico de quatro lotes de sementes através dos testes de germinação (Germ. - \%), primeira contagem de germinação ( $1^{\underline{a}}$ cont. - \%), envelhecimento acelerado (EA - \%), teste de frio (TF - \%), emergência de plântulas em campo (EPC - \%) e condutividade elétrica ( $\mu \mathrm{mho} / \mathrm{cm} / \mathrm{g}$ de semente).

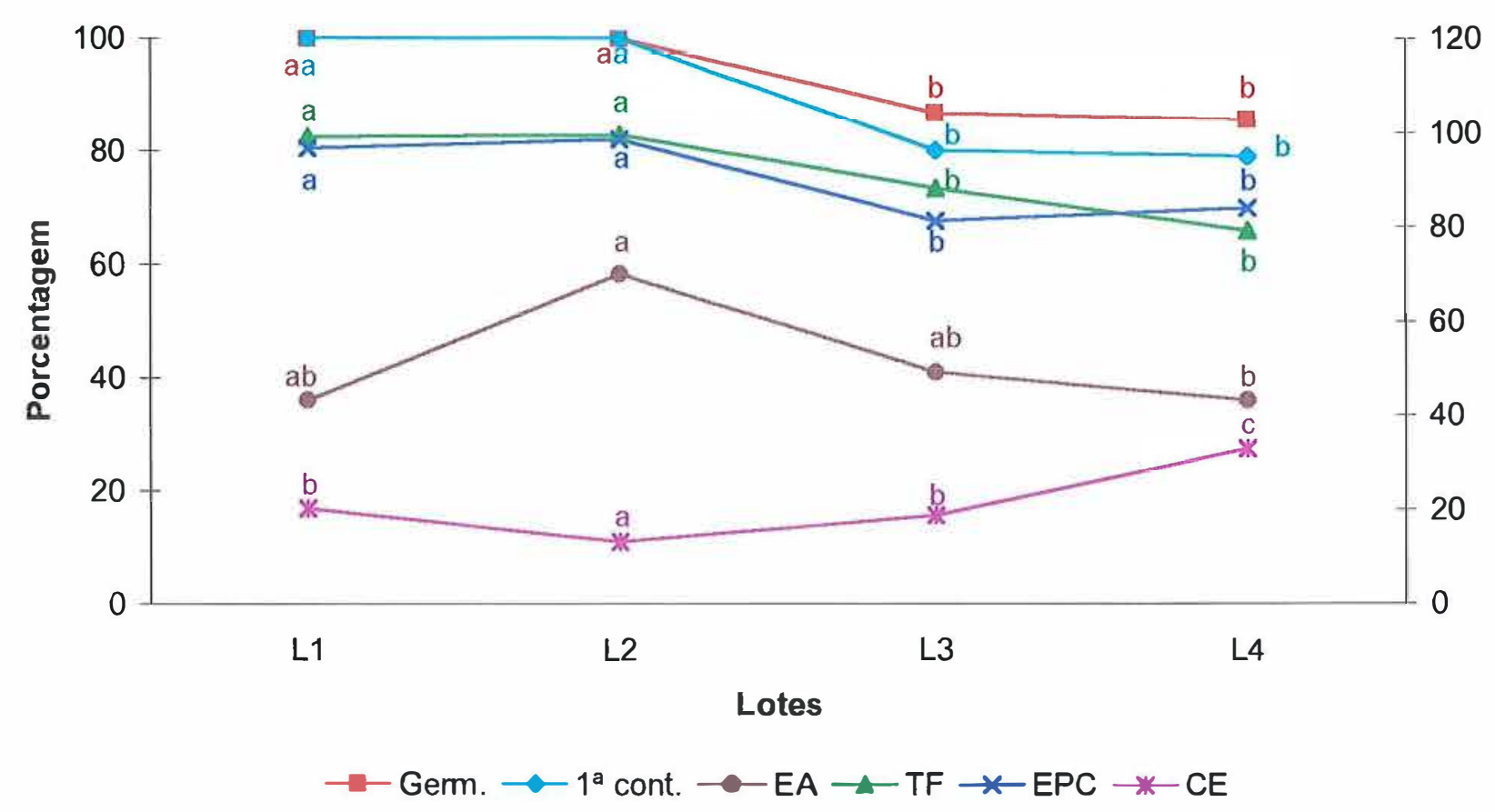

Portanto, de maneira geral, os testes de vigor foram eficientes na classificação dos lotes. Houve unanimidade na identificação do lote 2 como superior e do lote 4 como inferior. As posições dos lotes 1 e 3 variaram de acordo com o teste empregado. O lote 1, apontado como superior nos testes de primeira contagem de germinação, de frio e de emergência de 
plântulas em campo, ocupou posição intermediária nos testes de envelhecimento acelerado e de condutividade elétrica; o lote 3 , intermediário no envelhecimento acelerado e na condutividade elétrica, foi inferior na primeira contagem de germinação, no teste de frio e na emergência de plântulas em campo.

Assim pode-se verificar que, entre os lotes estudados o 2 apresentou potencial fisiológico superior, os lotes 1 e 3 comportamento intermediário e, o lote 4, o pior desempenho.

\subsubsection{Hibrido Traktor}

Os resultados da avaliação inicial da qualidade dos lotes do híbrido Traktor podem ser observados na Figura 4.

Os testes de germinação e de primeira contagem de germinação classificaram os lotes da mesma maneira e foram os mais sensiveis na detecção de diferenças de qualidade entre os lotes. O lote 4 apresentou o maior potencial fisiológico e, o lote 3, o menor. Os lotes 1, 2 e 5 ocuparam posição intermediária.

De acordo com os testes de envelhecimento acelerado e de condutividade elétrica, os lotes foram divididos em dois grupos; ou seja, os lotes $1,2,4$ e 5 foram superiores ao lote 3, que teve o pior desempenho fisiológico.

Os testes de frio e de emergência de plântulas em campo não foram sensiveis a possiveis diferenças de vigor entre os lotes; entretanto, numericamente, o lote 4 foi superior e o lote 3 inferior.

Pode-se observar que, de maneira geral, os cinco lotes estudados apresentaram níveis muito próximos de vigor, o que dificultou a separação de diferenças quanto ao potencial fisiológico pelos testes utilizados, com exceção do teste de primeira contagem de germinação que separou os lotes em três níveis. No entanto, houve consistência dos testes na classificação do lote 3 
como inferior, mesmo que, numericamente, no caso dos testes de frio e emergência de plântulas em campo e a tendência da identificação do lote 4 como numericamente superior, na maioria dos testes (frio, emergência de plântulas em campo e condutividade elétrica); na primeira contagem de germinação, o lote 4 foi estatisticamente superior aos demais.

Assim, houve tendência numérica em classificar o lote 4 como de potencial fisiológico superior, consistência na identificação do lote 3 como de potencial fisiológico inferior e dos lotes 2, 3 e 5 como intermediários.

Figura 4. Híbrido Traktor: resultados da avaliação do potencial fisiológico de quatro lotes de sementes através dos testes de germinação (Germ. - \%), primeira contagem de germinação (1 ${ }^{\underline{a}}$ cont. - \%), envelhecimento acelerado (EA - \%), teste de frio (TF - \%), emergência de plântulas em campo (EPC - \%) e condutividade elétrica ( $\mu \mathrm{mho} / \mathrm{cm} / \mathrm{g}$ de semente).

$a b a b$

$a b a b$
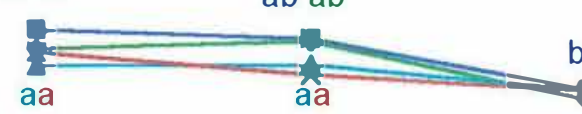

bb

aa

áa

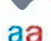

a

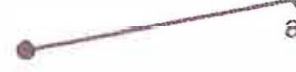

a

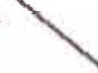

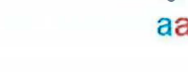

aa

$>$

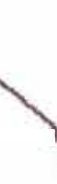

西

b

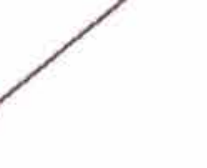

b

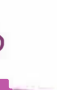
$a b a b$
aa
aa
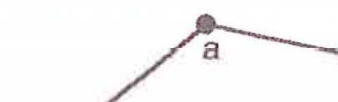

L1

L2

L3

L4

L5

Lotes

$\rightarrow-$ Germ. $\rightarrow 1^{\text {a }}$ Cont. $\longrightarrow$ EA $\rightarrow$ TF $\rightarrow$ EPC $\rightarrow$ CE 


\subsubsection{Teor de água das sementes}

Os dados referentes ao teor de água das sementes de cada um dos lotes dos híbridos Avant, AG 6690 e Traktor, embora não tenham sido analisados estatisticamente, apresentaram variações pouco acentuadas (Figura 5). Este fato é importante para a execução dos testes, considerando-se que a uniformização do teor de água das sementes é imprescindível para a padronização das avaliações e obtenção de resultados reproduziveis (Delouche, 1976; Matthews, 1981; Marcos Filho et al., 1987; Loeffler et al., 1988; Krzyzanowski et al., 1991; Vieira, 1994; Marcos Filho, 1999a).

Figura 5. Teor de água dos lotes dos híbridos Avant, AG 6690 e Traktor.

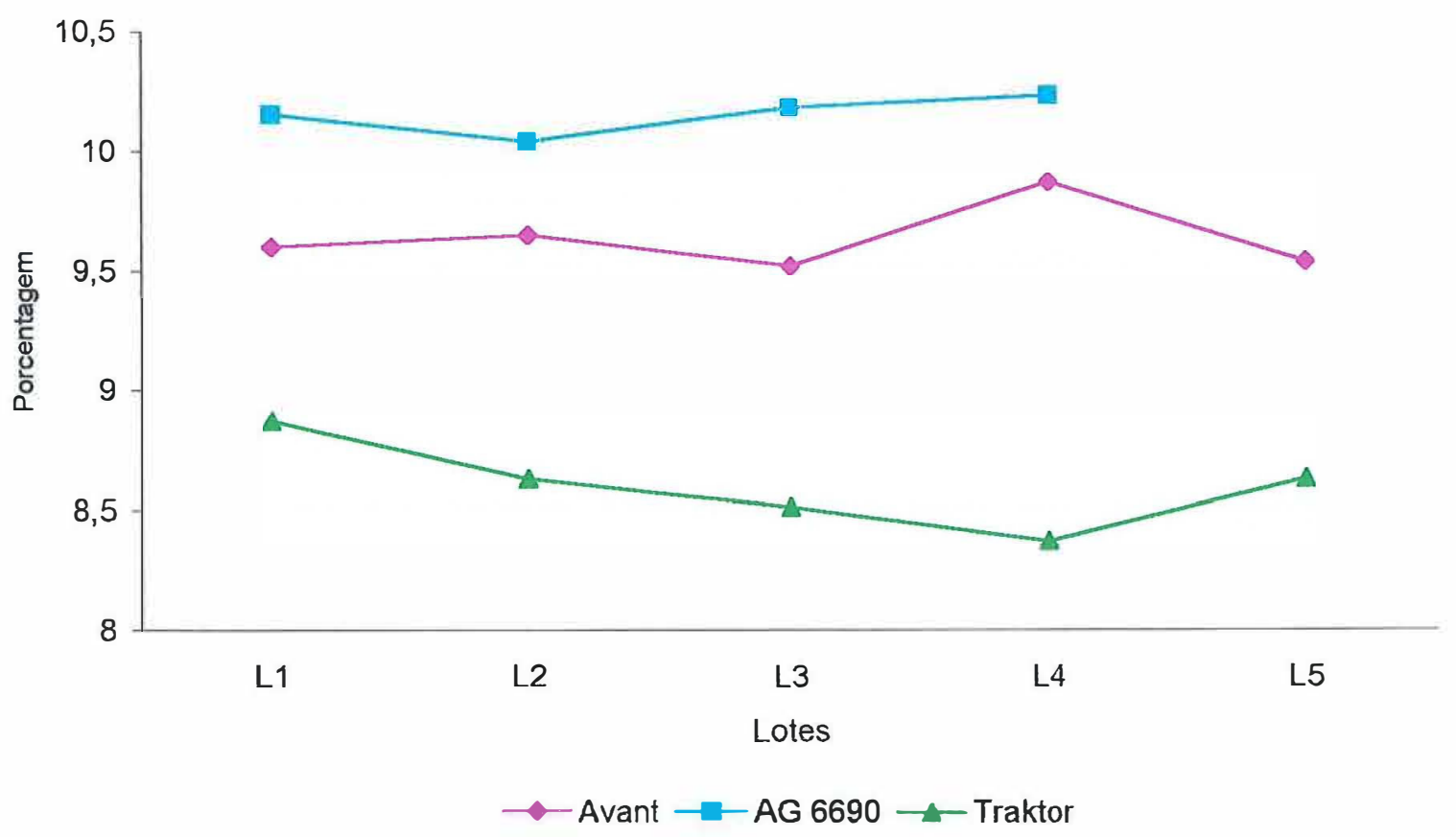


Ainda, recomenda-se monitorar o teor de água das sementes após o teste de envelhecimento acelerado, para verificar a uniformidade do mesmo (Krzyzanowski et al., 1991; Vieira, 1994; Marcos Filho, 1999a).

Os lotes do híbrido Avant atingiram teores de água uniformes, após o envelhecimento acelerado, que foram entre $20,2 \%$ e $22,2 \%$, os do hibrido AG 6690 entre $22,00 \%$ e $23,21 \%$ e os do híbrido Traktor entre $19,48 \%$ e $21,71 \%$ (Figura 6), indicando que as condições de alta umidade relativa do ar e alta temperatura mantidas no interior da câmara B.O.D. agiram de maneira semelhante sobre as sementes, garantindo a uniformidade do teste.

De acordo com Tomes et al. (1988) e Marcos Filho (1999b) é tolerável uma diferença de 3 a $4 \%$ no teor de água dos lotes, após o teste de envelhecimento acelerado. Portanto, as variações entre os teores de água das sementes dos lotes dos três híbridos, estavam dentro do limite aceitável.

Figura 6. Teores de água dos lotes dos híbridos Avant, AG 6690 e Traktor após o teste de envelhecimento acelerado.

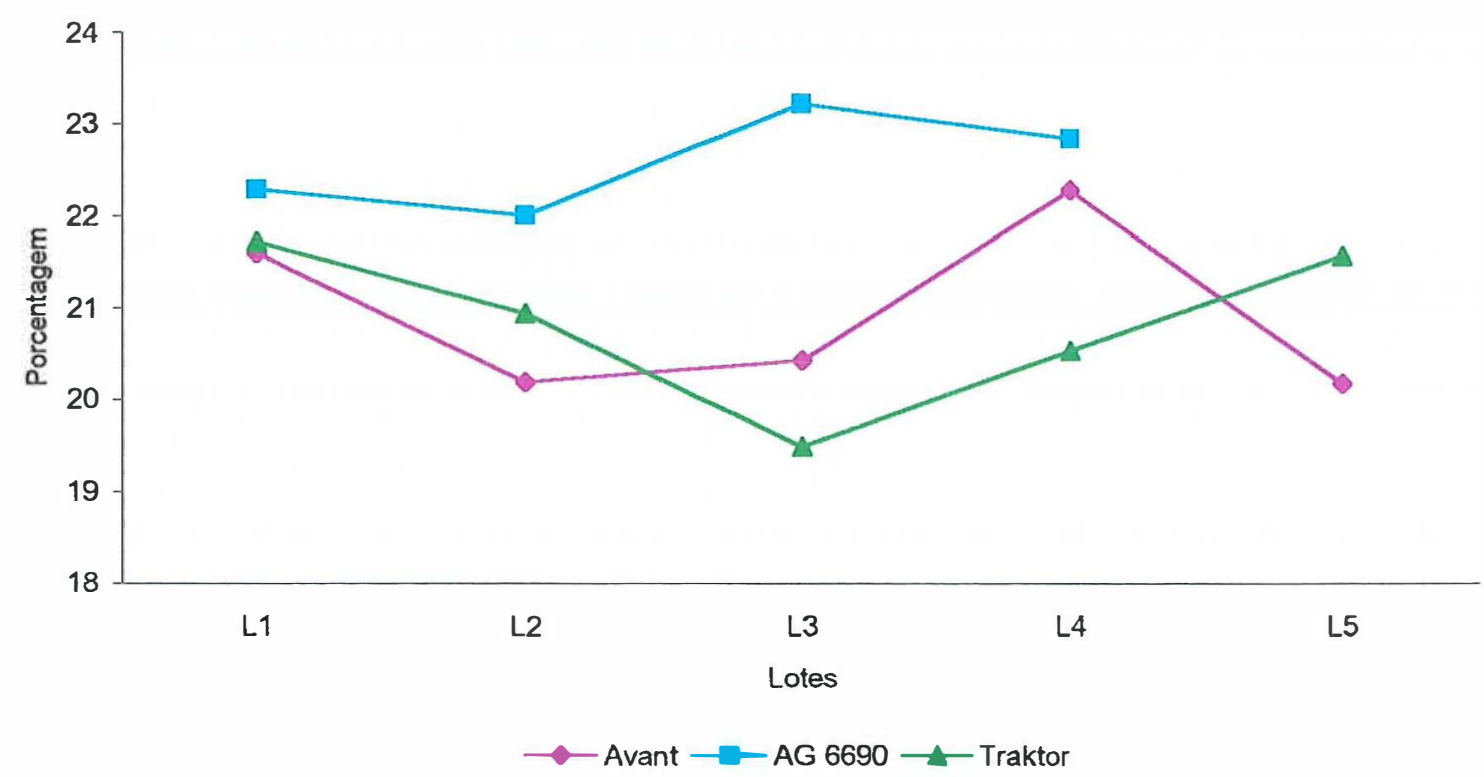




\subsubsection{Considerações Gerais}

A análise dos resultados dos testes de geminação permitiu verificar que todos os lotes apresentaram alta qualidade e se encontravam na Fase I, da curva de perda de viabilidade das sementes (Powell, 1986), uma vez que os resultados variaram entre $86 \%$ e $100 \%$.

Quanto ao potencial fisiológico das sementes, houve, em geral, coerência dos testes na determinação de níveis de vigor entre os lotes nos três híbridos estudados. No entanto, notou-se tendência de distinguir apenas os lotes de qualidades extremas, ou seja, os superiores e inferiores, não havendo consistência na classificação dos lotes de qualidade intermediária.

Realmente, a identificação de lotes de vigor intermediário pode sofrer variações em função da metodologia adotada, principalmente quando se trata de lotes com diferenças pouco acentuadas (McDonald e Wilson, 1979; Kulik e Yaklich, 1982; Marcos Filho et al., 1984; 1986).

Dessa forma, verifica-se a importância do uso de mais de um teste para determinar o vigor dos lotes de sementes (Marcos Filho, 1998), em função da influência dos procedimentos adotados e do uso de situações específicas de estresse para estimar o comportamento relativo dos lotes em campo (Woodstock, 1973; TeKrony e Egly, 1977; Carvalho e Nakagawa, 2000).

Nota-se, também, que os testes se comportaram de maneira diferente para cada híbrido estudado. Assim, um determinado teste foi eficaz na distinção de níveis de qualidade entre os lotes de um determinado híbrido e ineficaz em outro, como no caso do teste de envelhecimento acelerado que foi o mais eficiente na detecção de diferenças de vigor entre os lotes, apenas para o híbrido Avant. Esse fato sugere uma possível diferença de comportamento dos testes em função do híbrido estudado; isto vem sendo observado, com freqüência, pelas empresas produtoras de sementes de milho.

Além disso, pode-se verificar que apesar das pesquisas terem considerado com maior atenção os testes de frio e de envelhecimento 
acelerado para sementes de milho, os outros testes estudados mostraram-se coerentes na avaliação do potencial fisiológico dos lotes. Assim, o estudo da eficiência de outros testes que apresentem vantagens adicionais aos de frio e envelhecimento acelerado seria interessante, principalmente, no que diz respeito a diminuição do período necessário para obtenção de resultados confiáveis.

\subsection{Lixiviação de Potássio}

Os dados de lixiviação de potássio também foram apresentados em Figuras, sendo que cada uma delas representou um tratamento, nos diferentes períodos de embebição. Para a comparação entre as médias, cada linha representou o comportamento de um lote nos diferentes períodos de embebição. Assim, foi possivel a comparação entre lotes dentro de cada tratamento, tomando-se por base cada período de embebição.

\subsubsection{Híbrido Avant}

Em todos os tratamentos avaliados, nas duas temperaturas, nos diferentes períodos de embebição, ocorreu efeito significativo da interação tratamentos $\mathrm{x}$ lotes, indicando que os tratamentos interferiram na classificação dos lotes.

\subsubsection{Testes de lixiviação de potássio realizados a $25^{\circ} \mathrm{C}$}

Observa-se que, de maneira geral, os tratamentos, estudados para o teste de lixiviação de potássio classificaram os lotes de maneira semelhante (Figuras 7 a 18). Os lotes 1 e 4 apresentaram potencial fisiológico superior e 
diferiram estatisticamente dos lotes 2,3 e 5 . Nota-se que os lotes foram separados em dois grupos distintos, não havendo posições intermediárias como foi verificado nos testes de primeira contagem de germinação, de envelhecimento acelerado e de frio (Figura 2); os resultados obtidos nas duas épocas de avaliação foram coincidentes, confirmando a classificação dos lotes.

Esses resultados confirmam os fornecidos pelos testes de emergência de plântulas em campo e de condutividade elétrica (Figura 2), que também detectaram a superioridade dos lotes 1 e 4 em relação aos demais e concordam parcialmente com os demais testes, em relação aos lotes 1 e 3 , na maioria dos tratamentos.

Entretanto, o teste de lixiviação de potássio não foi suficientemente sensivel para detectar diferenças menos acentuadas de vigor entre os lotes. Assim, a identificação de qualidades intermediárias, entre os lotes, não foi possivel.

Para as determinações da lixiviação de potássio nos tratamentos com 100 sementes $/ 50 \mathrm{ml}$ e com 50 sementes $/ 25 \mathrm{ml}$, em todos os períodos de embebição nas épocas 1 e 2, foram necessárias diluições das amostras das soluções de embebição. O mesmo ocorreu com o tratamento de 25 sementes/25 ml, nos períodos de 120, 150 e 180 minutos de embebição, apenas na época 1. Devido aos motivos já citados no item 4.1, estes tratamentos foram desconsiderados, por contribuirem para a menor rapidez e praticidade do teste de lixiviação de potássio, além da menor confiabilidade nos resultados; o uso de diluições aumentaria a variabilidade e conseqüentemente 0 coeficiente de variação dos dados. 
Figura 7. Híbrido Avant: comportamento dos cinco lotes de sementes, quanto à lixiviação de potássio, no tratamento 100 sementes $/ 75 \mathrm{ml} / 25^{\circ} \mathrm{C}$ (época 1).

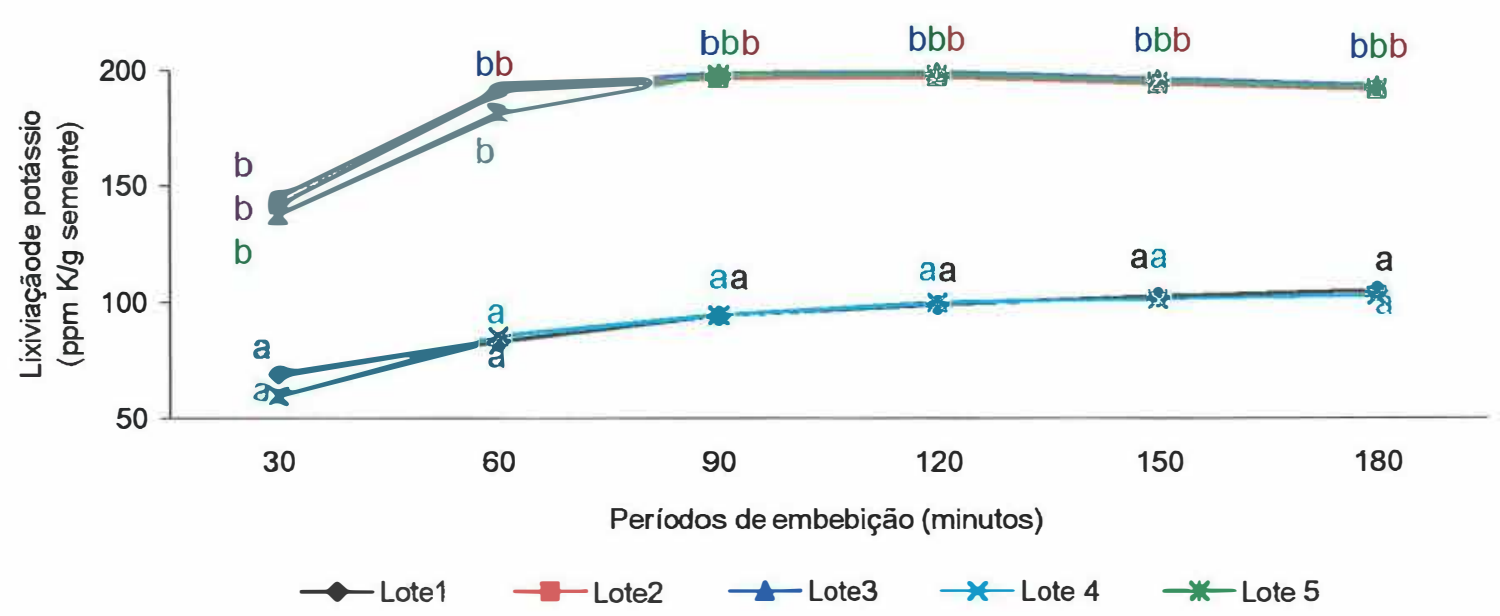

Figura 8. Híbrido Avant: comportamento dos cinco lotes de sementes, quanto à lixiviação de potássio, no tratamento 100 sementes $/ 75 \mathrm{ml} / 25^{\circ} \mathrm{C}$ (época 2).

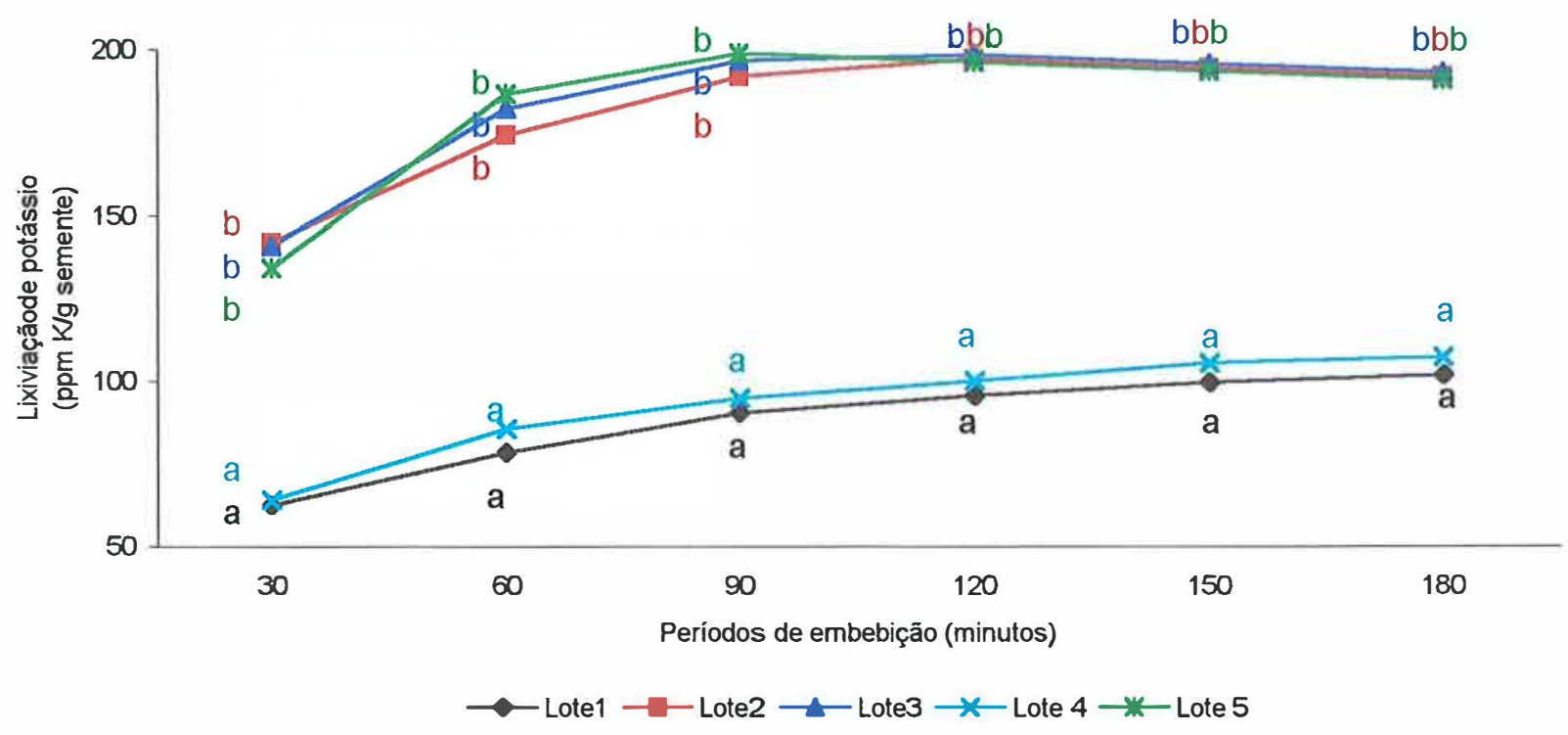


Figura 9. Híbrido Avant: comportamento dos cinco lotes de sementes, quanto à lixiviação de potássio, no tratamento 50 sementes $/ 75 \mathrm{ml} / 25^{\circ} \mathrm{C}$ (época 1).

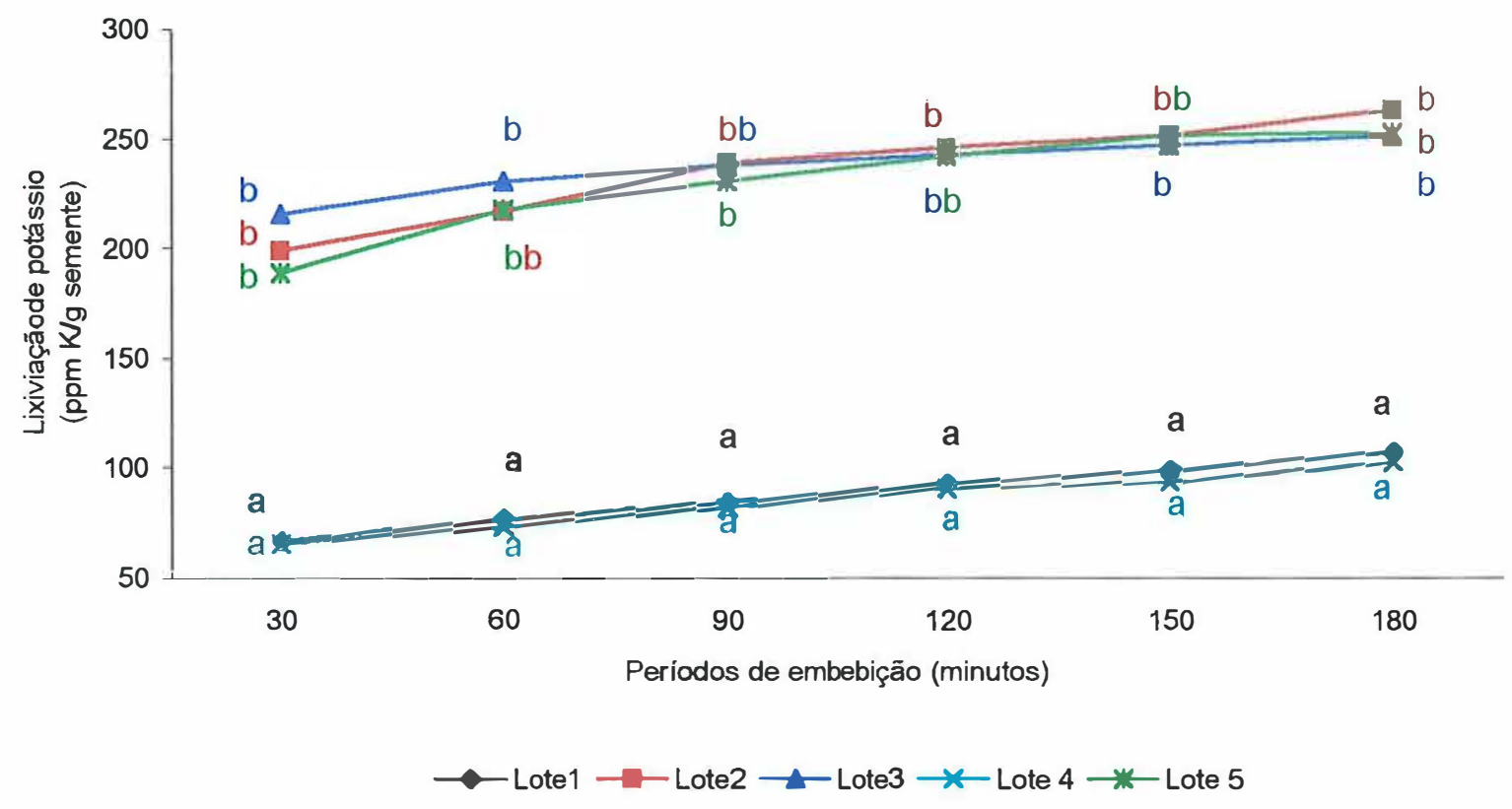

Figura 10. Híbrido Avant: comportamento dos cinco lotes de sementes, quanto à lixiviação de potássio, no tratamento 50 sementes $/ 50 \mathrm{ml} / 25^{\circ} \mathrm{C}$ (época 1 ).

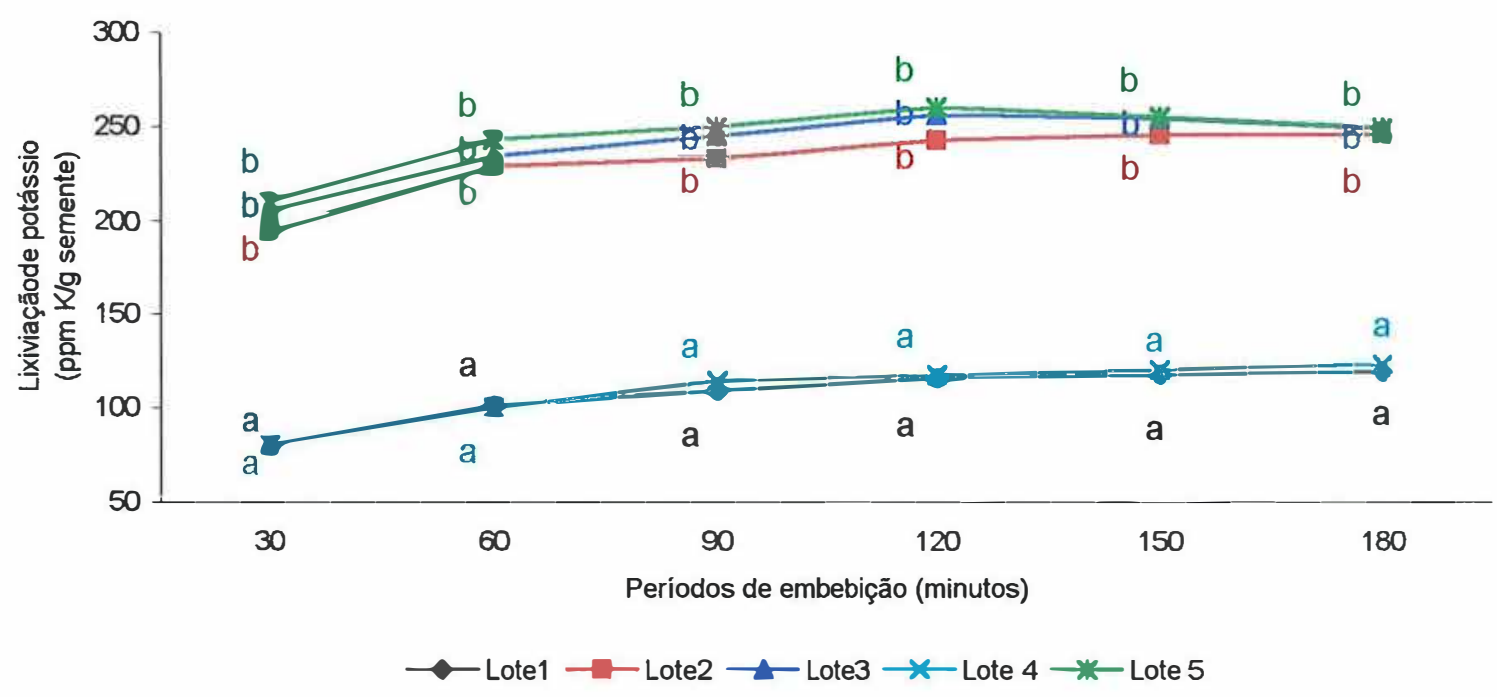


Figura 11. Híbrido Avant: comportamento dos cinco lotes de sementes, quanto à lixiviação de potássio, no tratamento 50 sementes $/ 75 \mathrm{ml} / 25^{\circ} \mathrm{C}$ (época 2).

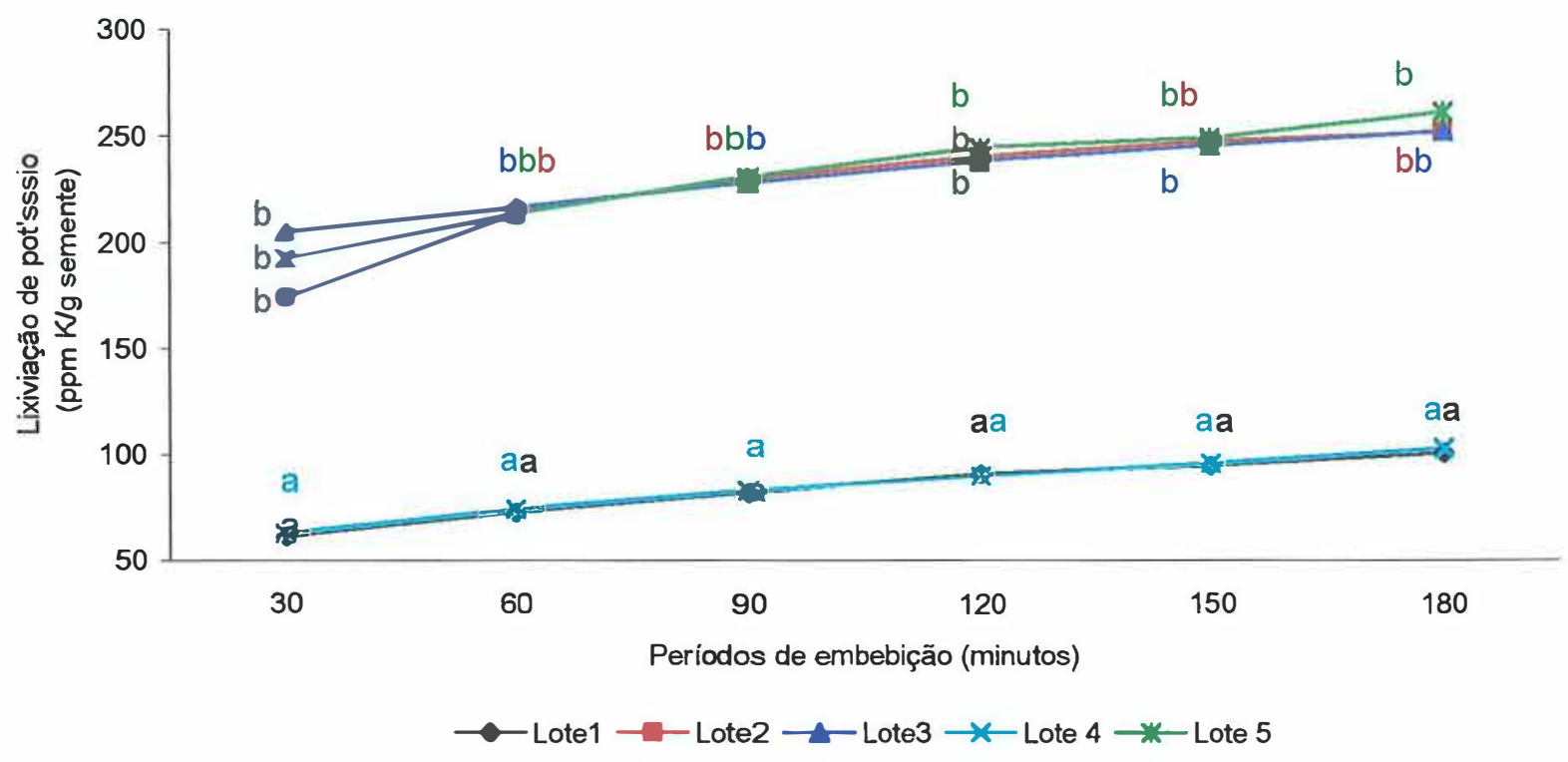

Figura 12. Híbrido Avant: comportamento dos cinco lotes de sementes, quanto à lixiviação de potássio, no tratamento 50 sementes $/ 50 \mathrm{ml} / 25^{\circ} \mathrm{C}$ (época 2).

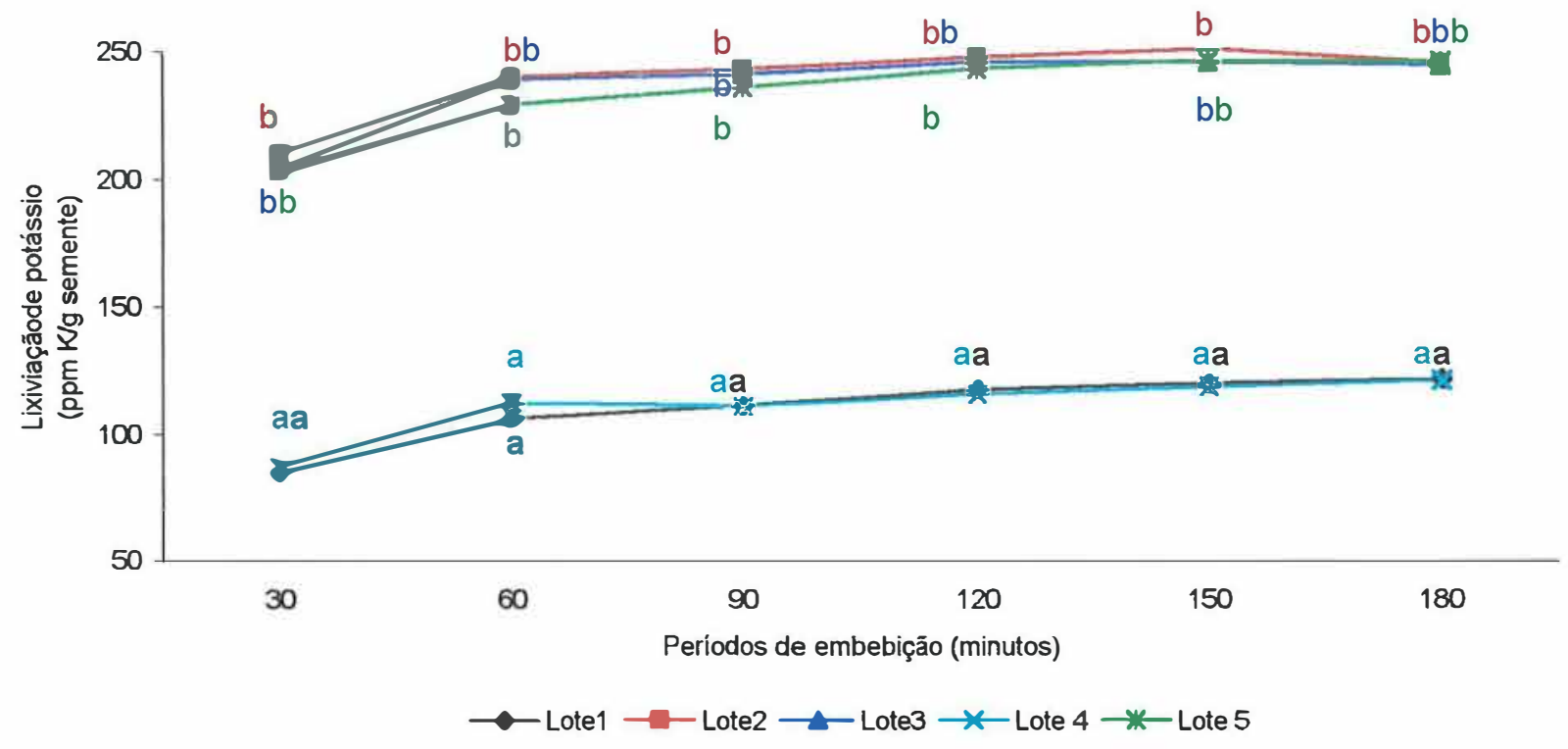


Figura 13. Híbrido Avant: comportamento dos cinco lotes de sementes, quanto à lixiviação de potássio, no tratamento 25 sementes $/ 75 \mathrm{ml} / 25^{\circ} \mathrm{C}$ (época 1).

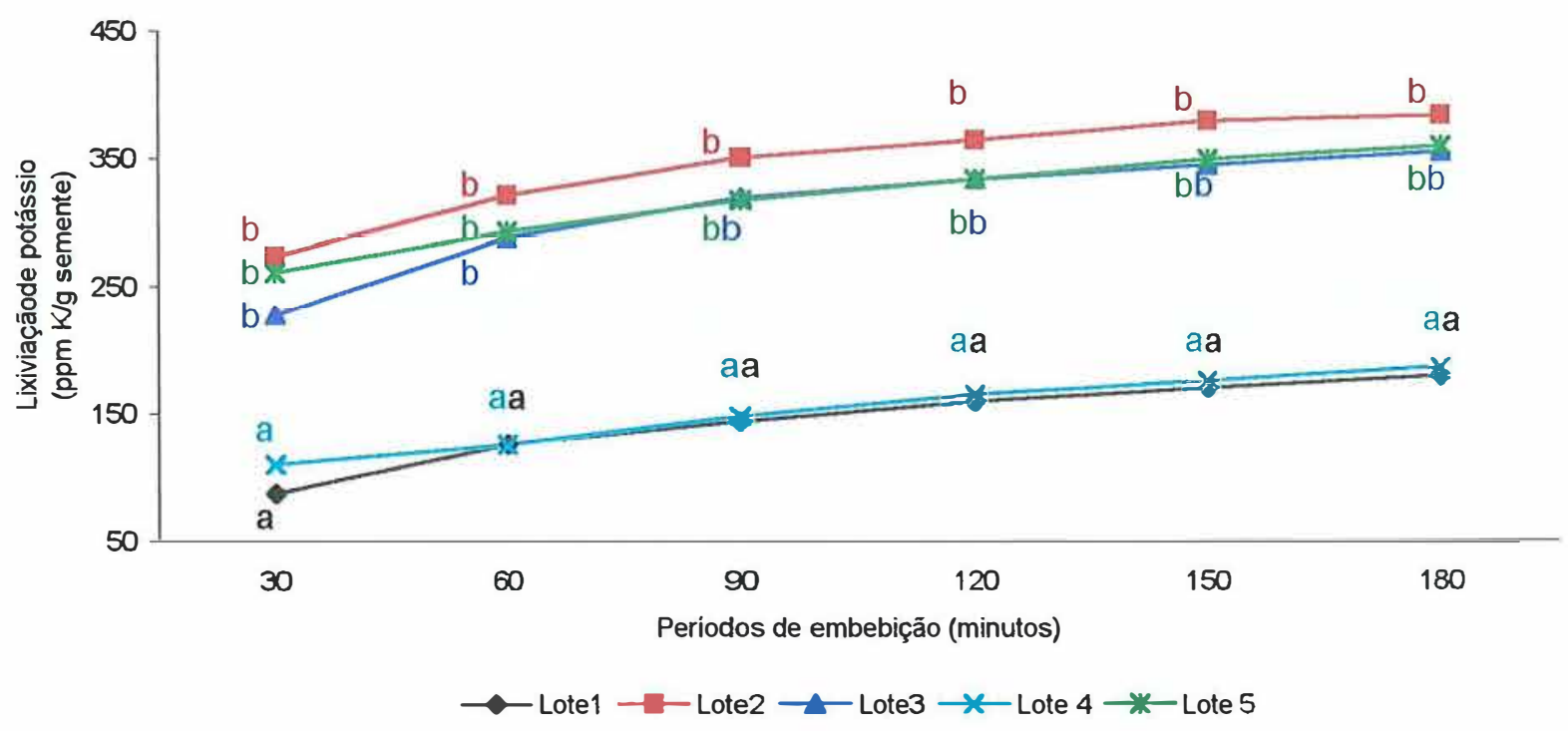

Figura 14. Híbrido Avant: comportamento dos cinco lotes de sementes, quanto à lixiviação de potássio, no tratamento 25 sementes $/ 50 \mathrm{ml} / 25^{\circ} \mathrm{C}$ (época 1).

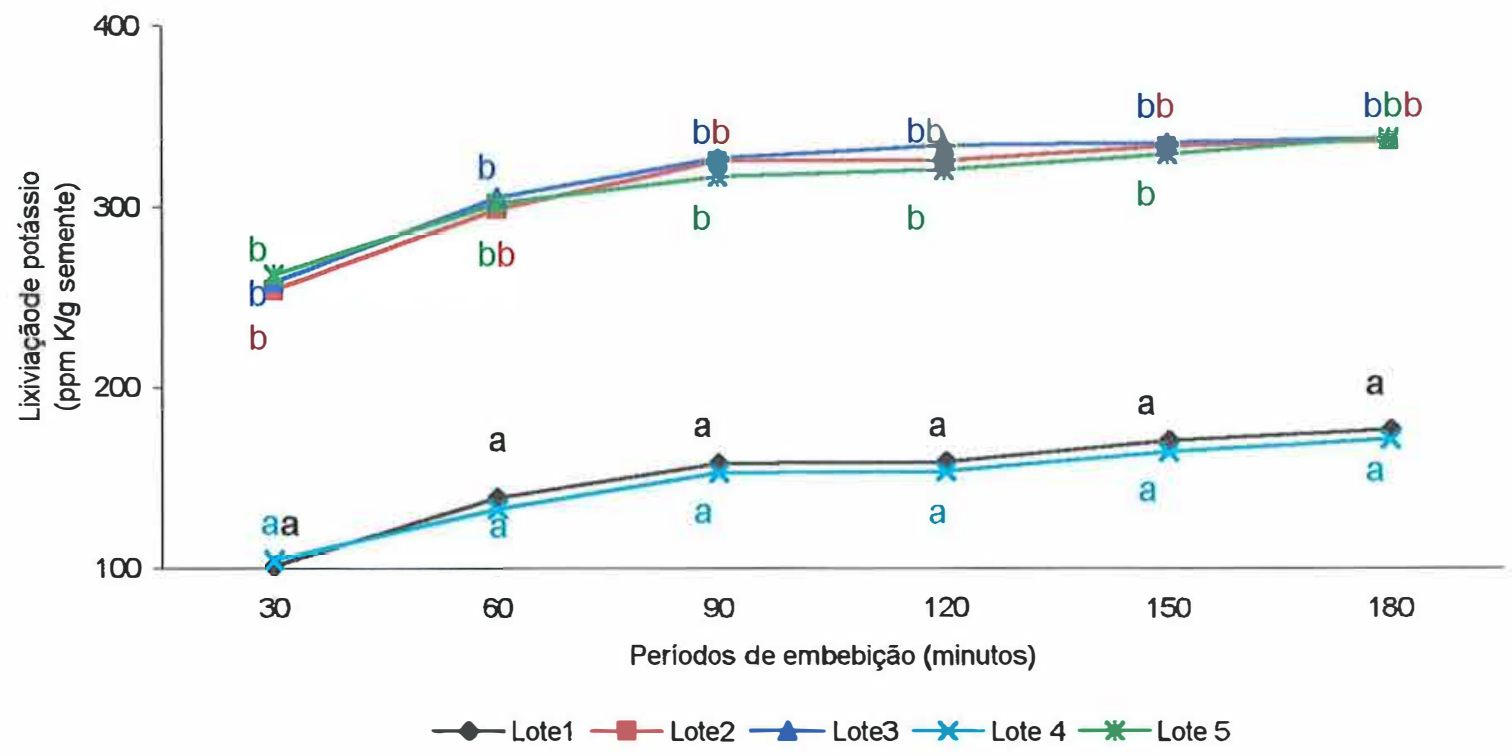


Figura 15. Híbrido Avant: comportamento dos cinco lotes de sementes, quanto à lixiviação de potássio, no tratamento 25 sementes $/ 25 \mathrm{ml} / 25^{\circ} \mathrm{C}$ (época 1).

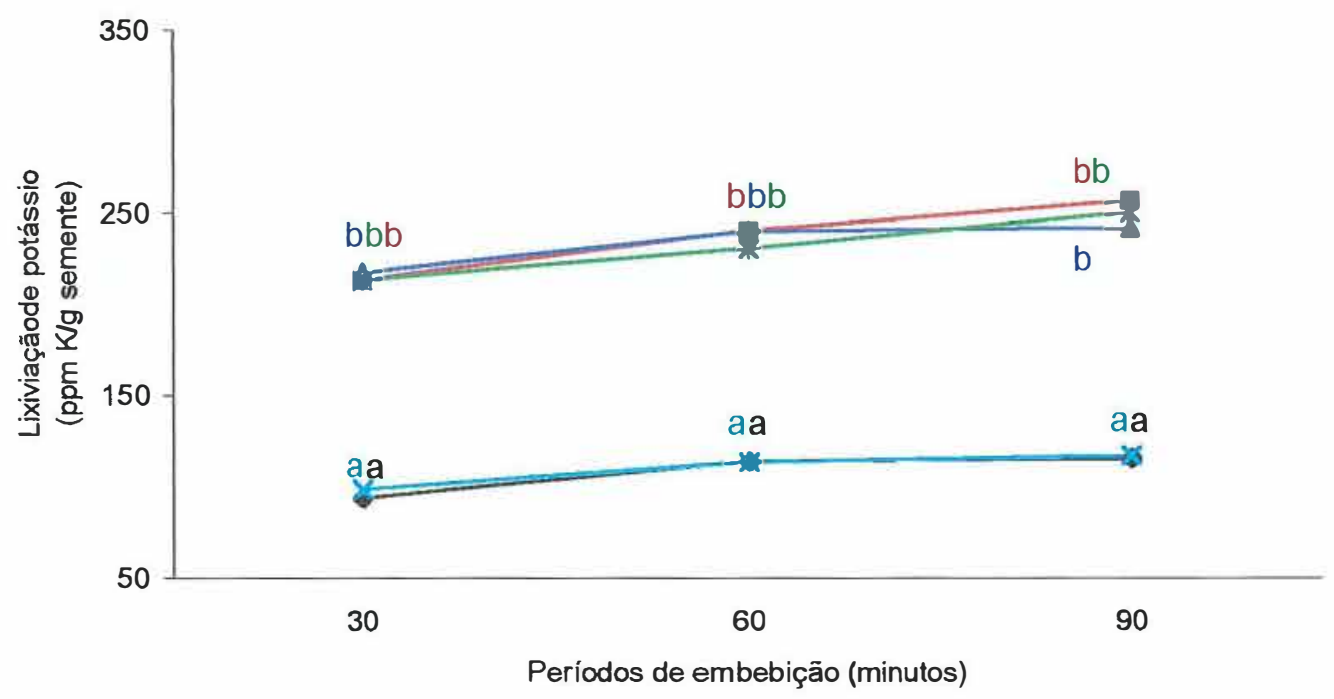

$\longrightarrow$ Lote $1 \rightarrow$ Lote $2 \rightarrow$ Lote $3 \rightarrow$ Lote $4 \rightarrow$ Lote 5

Figura 16. Híbrido Avant: comportamento dos cinco lotes de sementes, quanto à lixiviação de potássio, no tratamento 25 sementes $/ 75 \mathrm{ml} / 25^{\circ} \mathrm{C}$ (época 2).

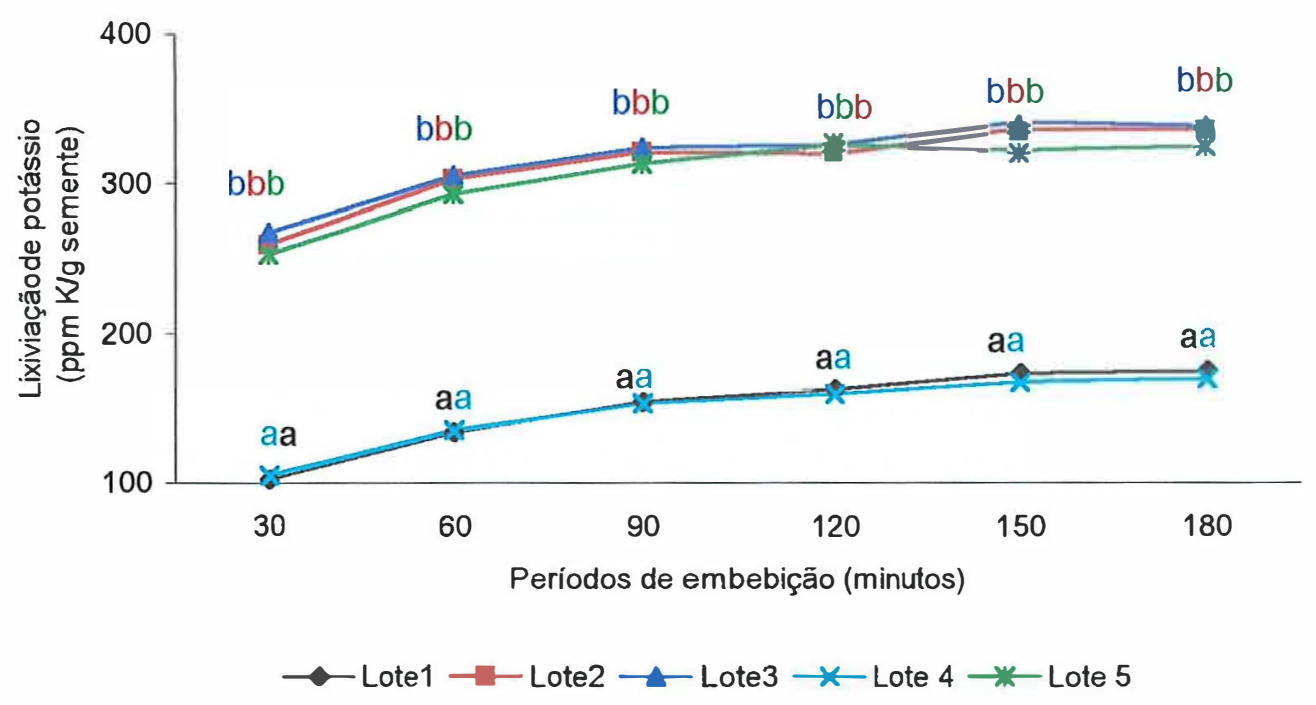


Figura 17. Híbrido Avant: comportamento dos cinco lotes de sementes, quanto à lixiviação de potássio, no tratamento 25 sementes $/ 50 \mathrm{ml} / 25^{\circ} \mathrm{C}$ (época 2).

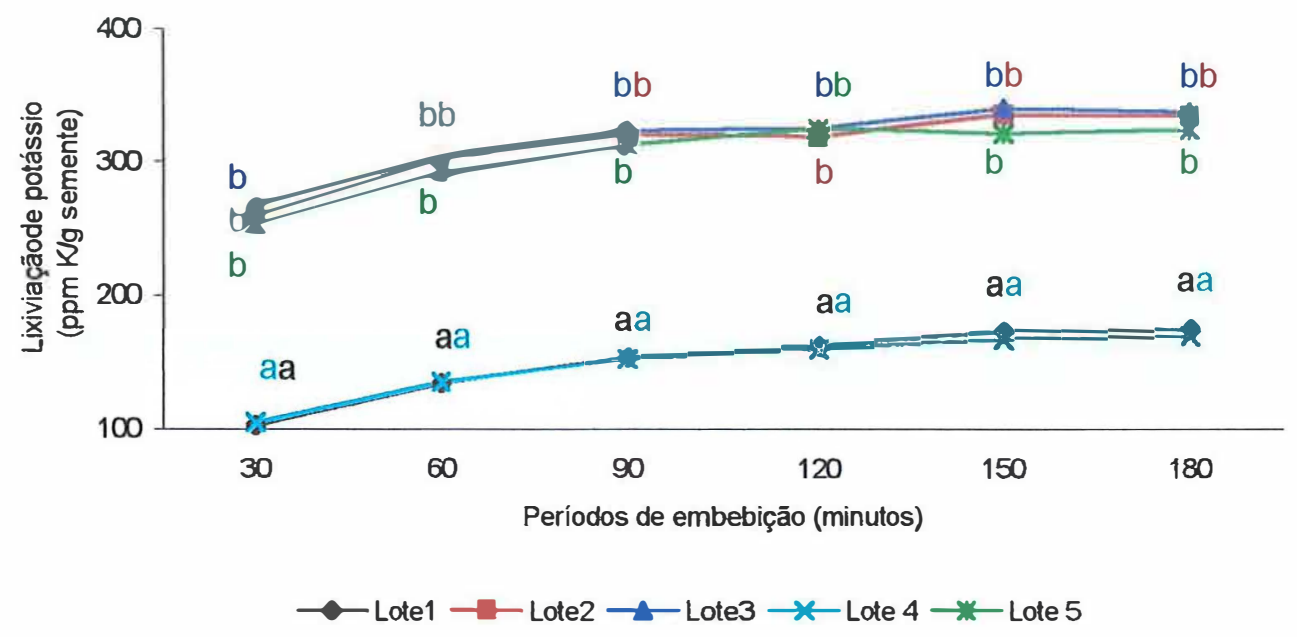

Figura 18. Híbrido Avant: comportamento dos cinco lotes de sementes, quanto à lixiviação de potássio, no tratamento 25 sementes $/ 25 \mathrm{ml} / 25^{\circ} \mathrm{C}$ (época 2).

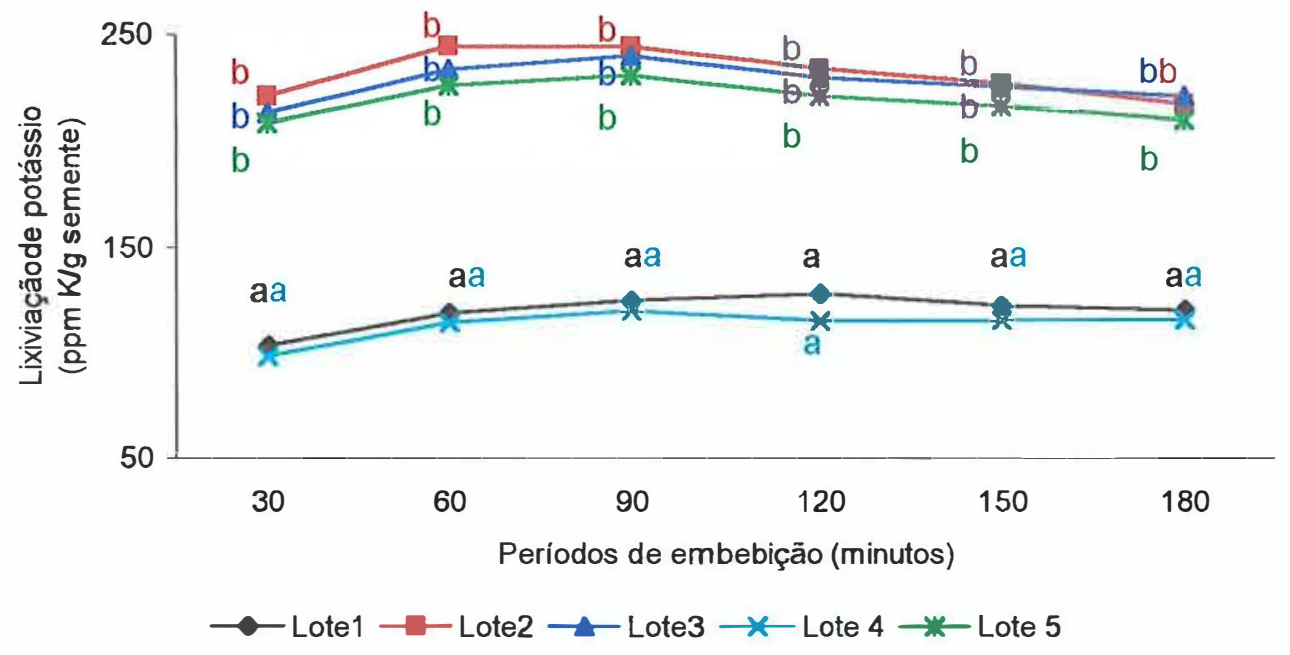


Assim, de um modo geral, todos os tratamentos foram eficientes na classificação dos lotes, em função do potencial fisiológico.

$E$ É interessante ressaltar que os coeficientes de variação foram baixos $(5,0$ a $11,6 \%)$ e que as variações entre eles, de acordo com o período de embebição, foi desprezivel, não influenciando, portanto, na eficiência do tratamento $e$, ainda que, as pequenas diferenças entre os tratamentos não foram suficientes para diminuir a eficiência do teste.

\subsubsection{Testes de lixiviação de potássio a $30^{\circ} \mathrm{C}$}

Os dados referentes à lixiviação de potássio, sob embebição a $30^{\circ} \mathrm{C}$ encontram-se nas Figuras 19 a 30. Praticamente todas as observações feitas quanto à classificação dos lotes em relação ao potencial fisiológico, para os testes realizados a $25^{\circ} \mathrm{C}$, são válidas para os realizadas a $30^{\circ} \mathrm{C}$, ou seja, de maneira geral, os lotes 1 e 4 destacaram-se como superiores aos lotes 2,3 e 5 (Figuras 19 a 30).

Houve exceções para os tratamentos de 25 sementes $/ 75 \mathrm{ml}$ com 30 minutos de embebição, na época 1 (Figura 25) e com 25 sementes/ $25 \mathrm{ml}$ com 30, 60 e 90 minutos de embebição, na época 2 (Figura 30). Nesses casos o lote 2 foi classificado como o de menor potencial fisiológico, contrariando os resultados dos testes preliminares. Esta exceção não foi suficiente para diminuir a eficiência do teste de lixiviação de potássio na avaliação do potencial fisiológico das sementes do híbrido Avant.

As determinações da lixiviação de potássio nos tratamentos com 100 sementes $/ 50 \mathrm{ml}$ e com 50 sementes $/ 25 \mathrm{ml}$, em todos os períodos de embebição e nas duas épocas, foram descartadas devido à necessidade de diluição das amostras de solução de embebição, fato não recomendável como anteriormente comentado. 
Figura 19. Híbrido Avant: comportamento dos cinco lotes de sementes, quanto à lixiviação de potássio, no tratamento 100 sementes $/ 75 \mathrm{ml} / 30^{\circ} \mathrm{C}$ (época 1 ).

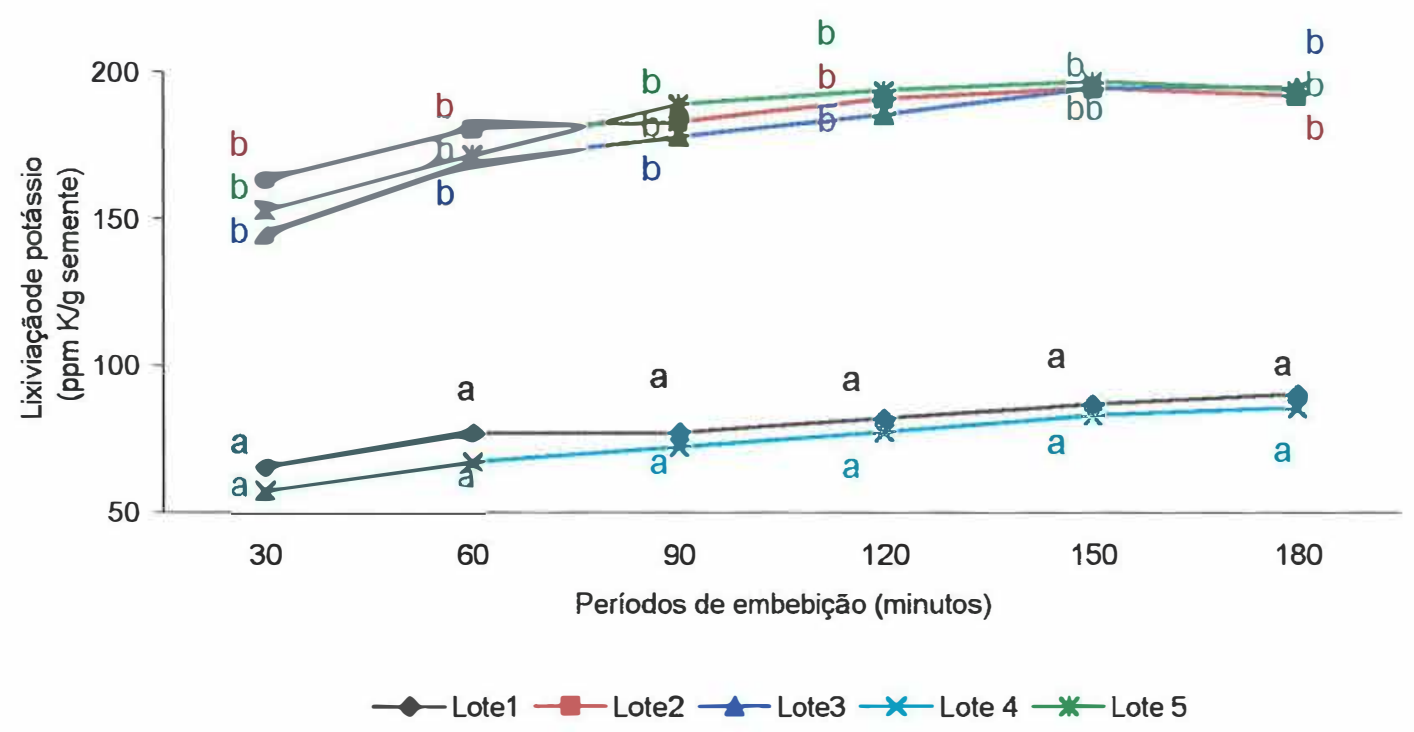

Figura 20. Híbrido Avant: comportamento dos cinco lotes de sementes, quanto à lixiviação de potássio, no tratamento 100 sementes $/ 75 \mathrm{ml} / 30^{\circ} \mathrm{C}$ (época 2).

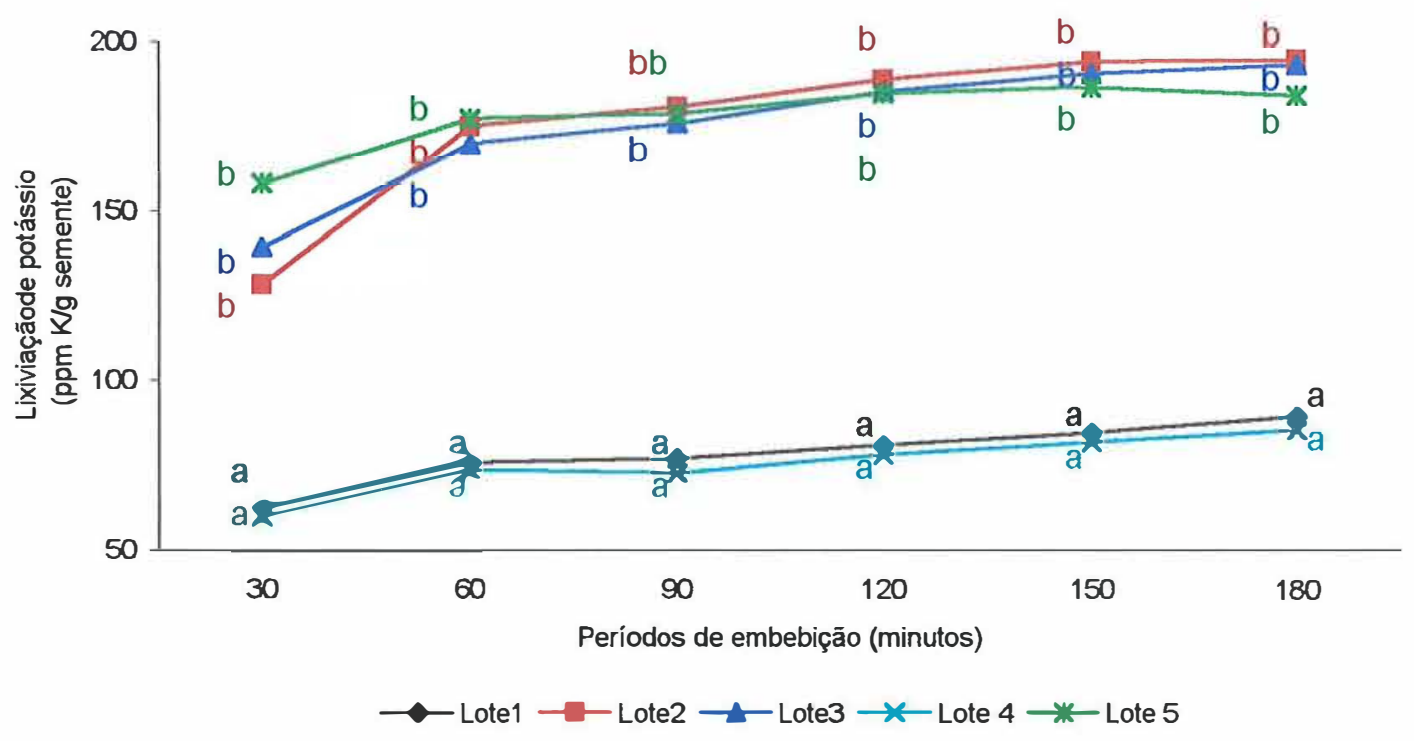


Figura 21. Híbrido Avant: comportamento dos cinco lotes de sementes, quanto à lixiviação de potássio, no tratamento 50 sementes $/ 75 \mathrm{ml} / 30^{\circ} \mathrm{C}$ (época 1).

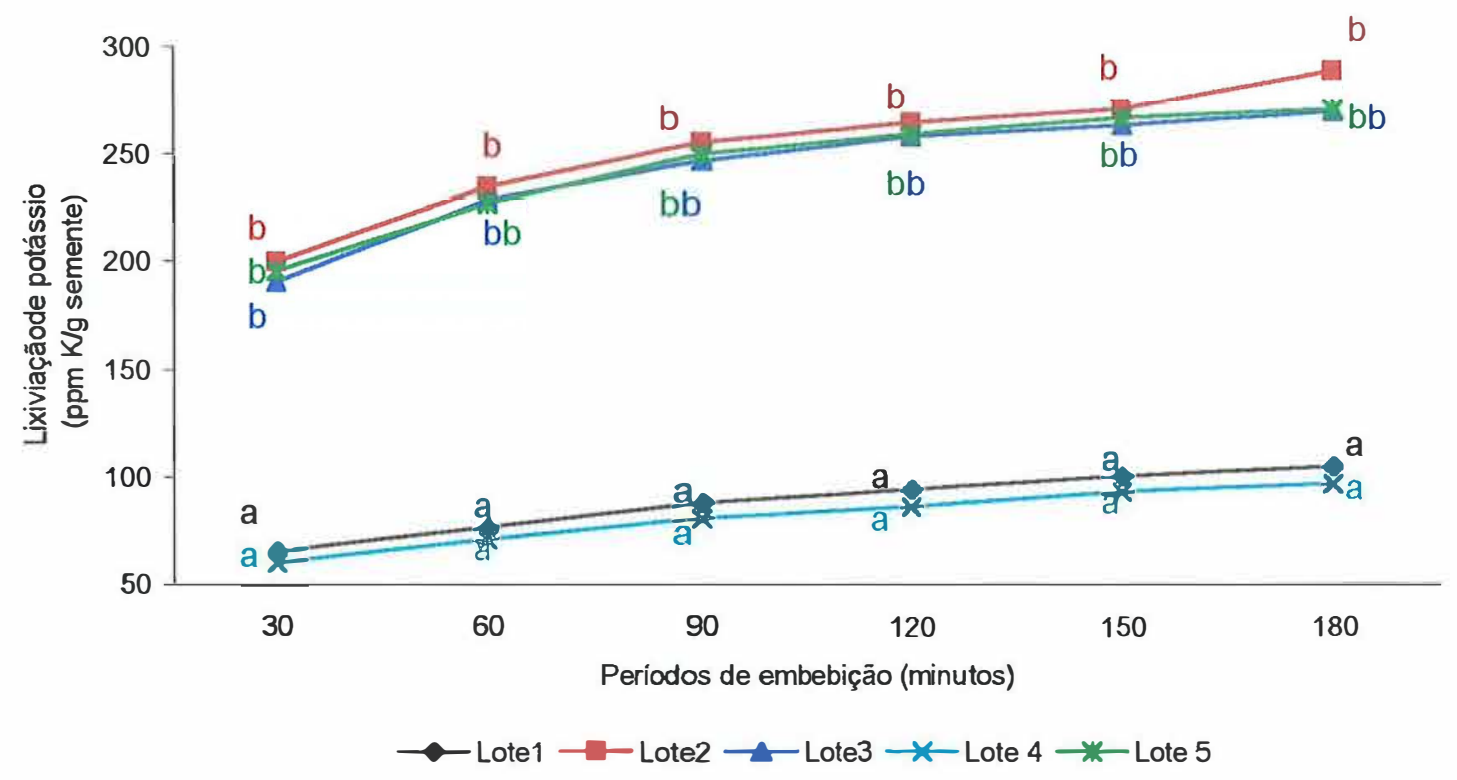

Figura 22. Híbrido Avant: comportamento dos cinco lotes de sementes, quanto à lixiviação de potássio, no tratamento 50 sementes $/ 50 \mathrm{ml} / 30^{\circ} \mathrm{C}$ (época 1).

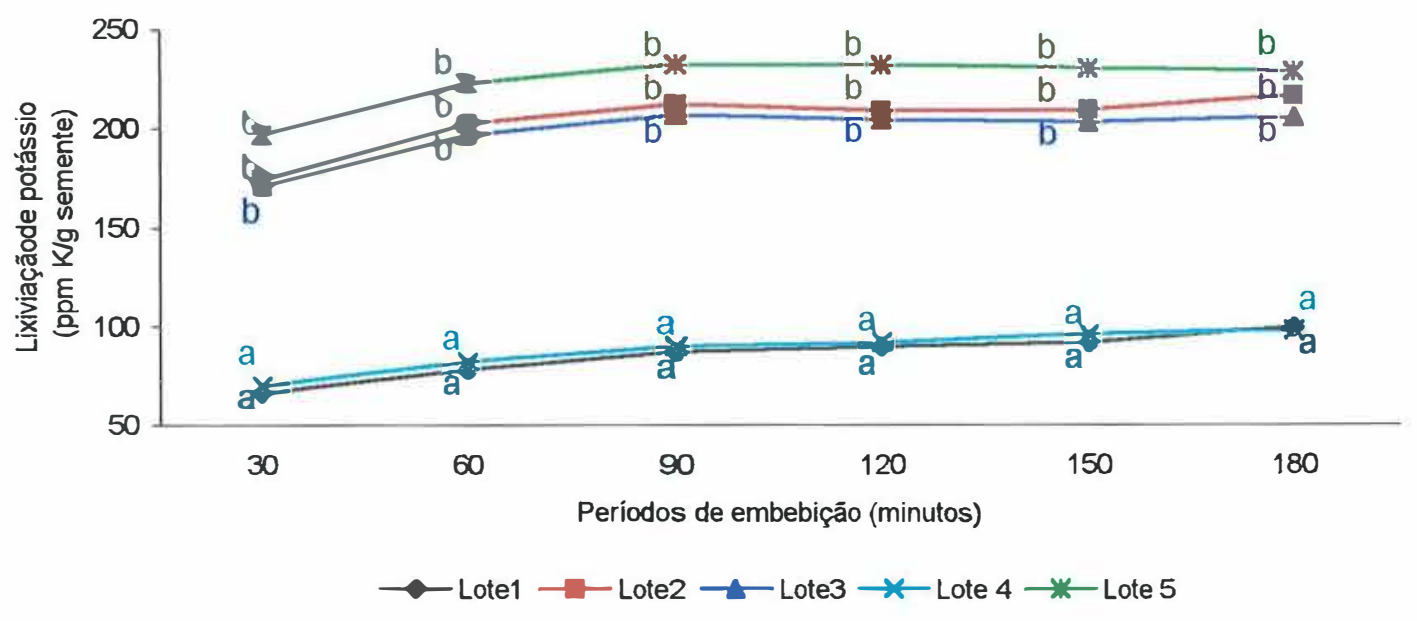


Figura 23. Híbrido Avant: comportamento dos cinco lotes de sementes,, quanto à lixiviação de potássio, no tratamento 50 sementes $/ 75 \mathrm{ml} / 30^{\circ} \mathrm{C}$ (época 2).

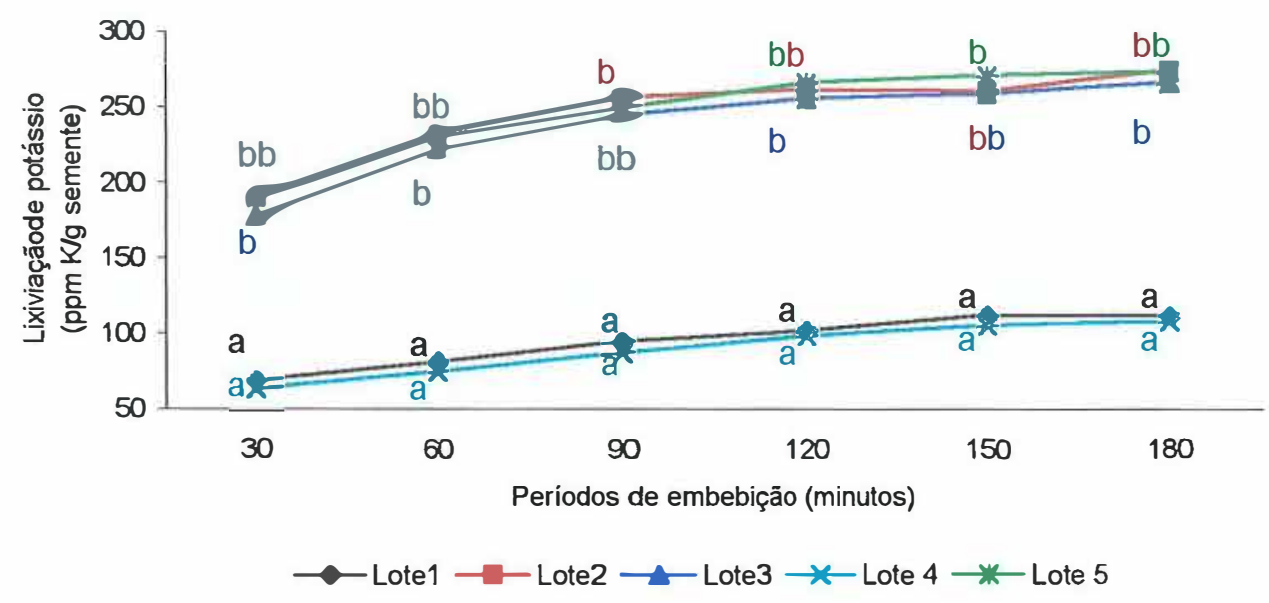

Figura 24. Híbrido Avant: comportamento dos cinco lotes de sementes, quanto à lixiviação de potássio, no tratamento 50 sementes $/ 75 \mathrm{ml} / 30^{\circ} \mathrm{C}$ (época 2).

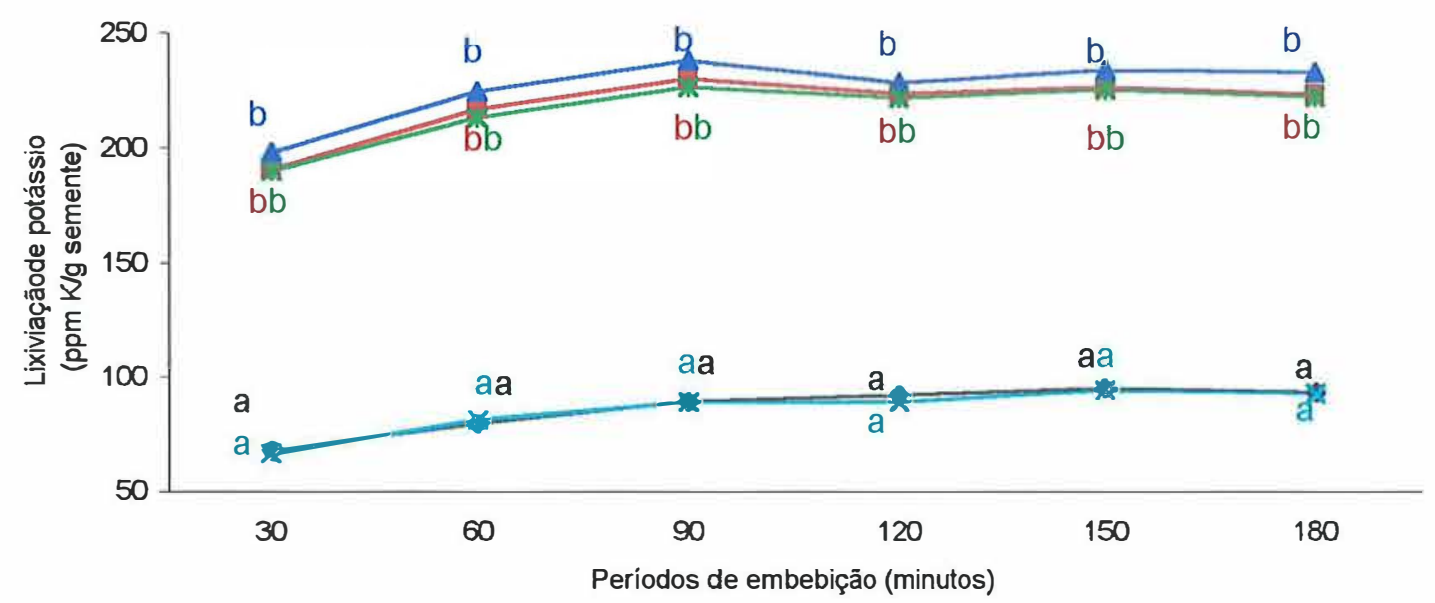


Figura 25. Híbrido Avant: comportamento dos cinco lotes de sementes, quanto à lixiviação de potássio, no tratamento 25 sementes $/ 75 \mathrm{ml} / 30^{\circ} \mathrm{C}$ (época 1).

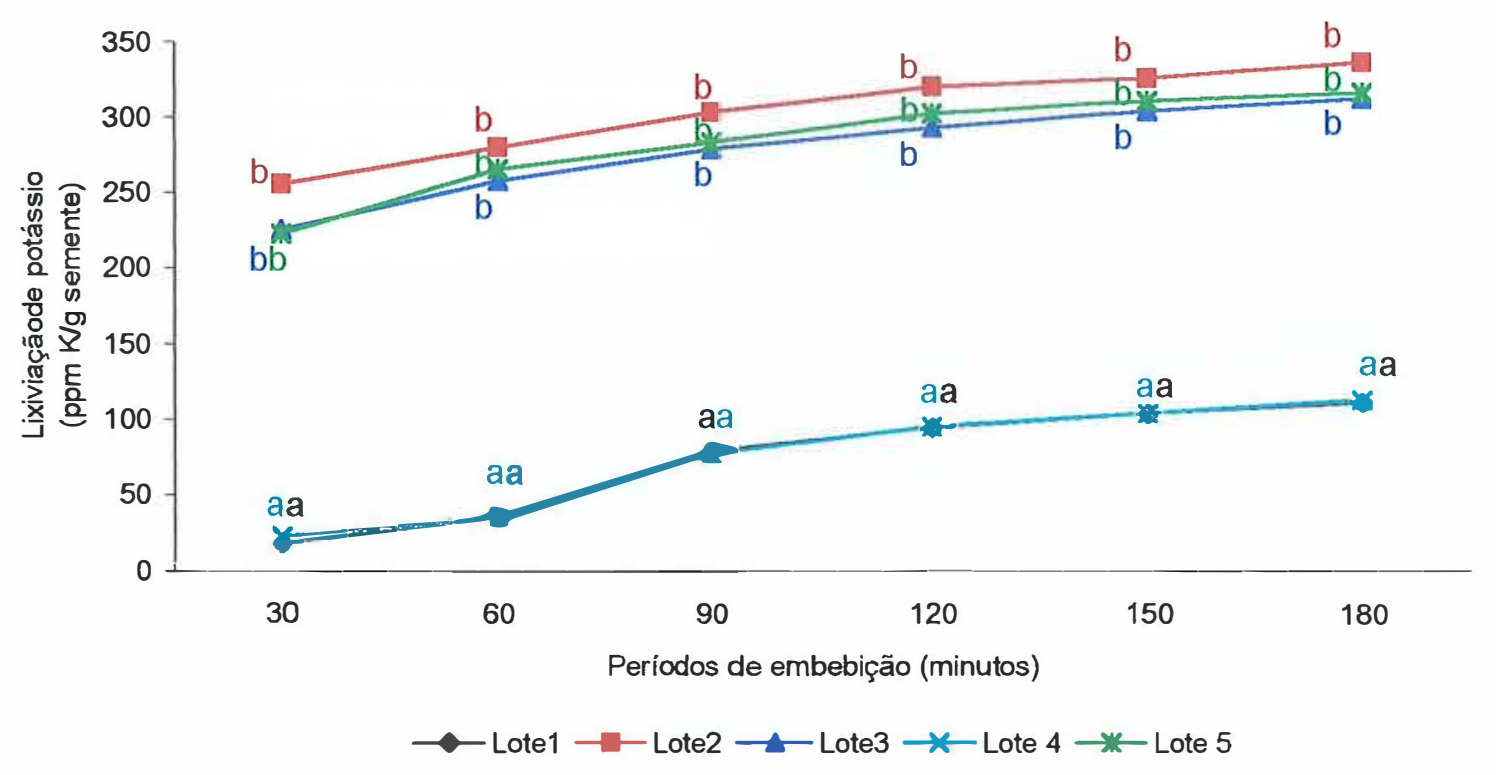

Figura 26. Híbrido Avant: comportamento dos cinco lotes de sementes, quanto à lixiviação de potássio, no tratamento 25 sementes $/ 50 \mathrm{ml} / 30^{\circ} \mathrm{C}$ (época 1).

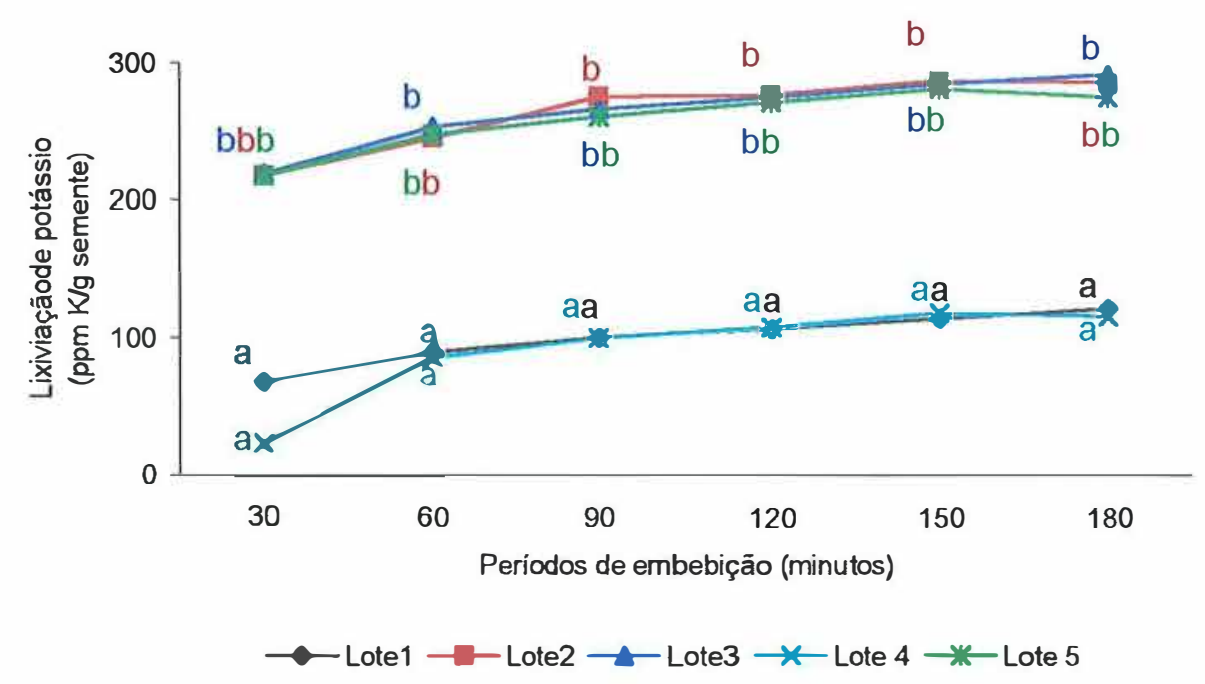


Figura 27. Híbrido Avant: comportamento dos cinco lotes de sementes, quanto à lixiviação de potássio, no tratamento 25 sementes $/ 25 \mathrm{ml} / 30^{\circ} \mathrm{C}$ (época 1).

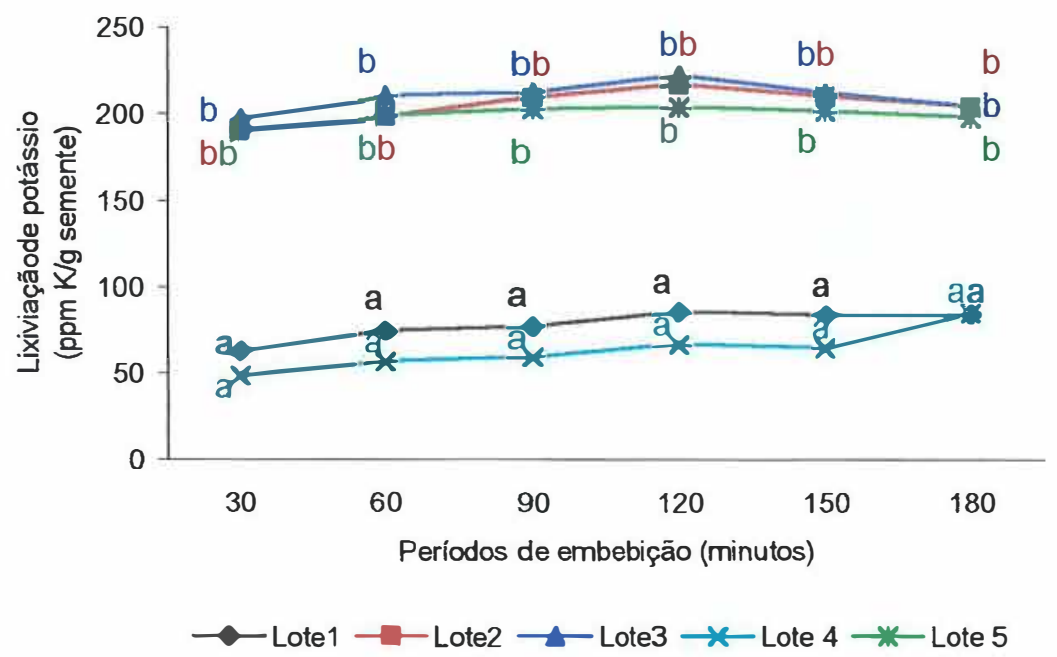

Figura 28. Híbrido Avant: comportamento dos cinco lotes de sementes, quanto à lixiviação de potássio, no tratamento 25 sementes $/ 75 \mathrm{ml} / 30^{\circ} \mathrm{C}$ (época 2).

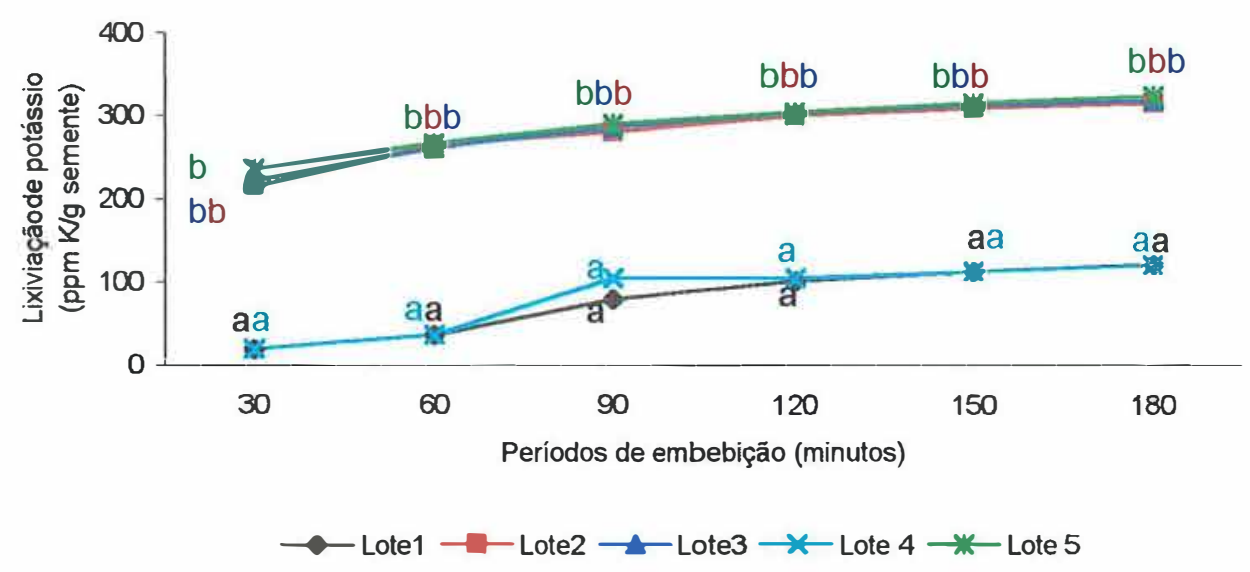


Figura 29. Híbrido Avant: comportamento dos cinco lotes de sementes, quanto à lixiviação de potássio, no tratamento 25 sementes $/ 50 \mathrm{ml} / 30^{\circ} \mathrm{C}$ (época 2).

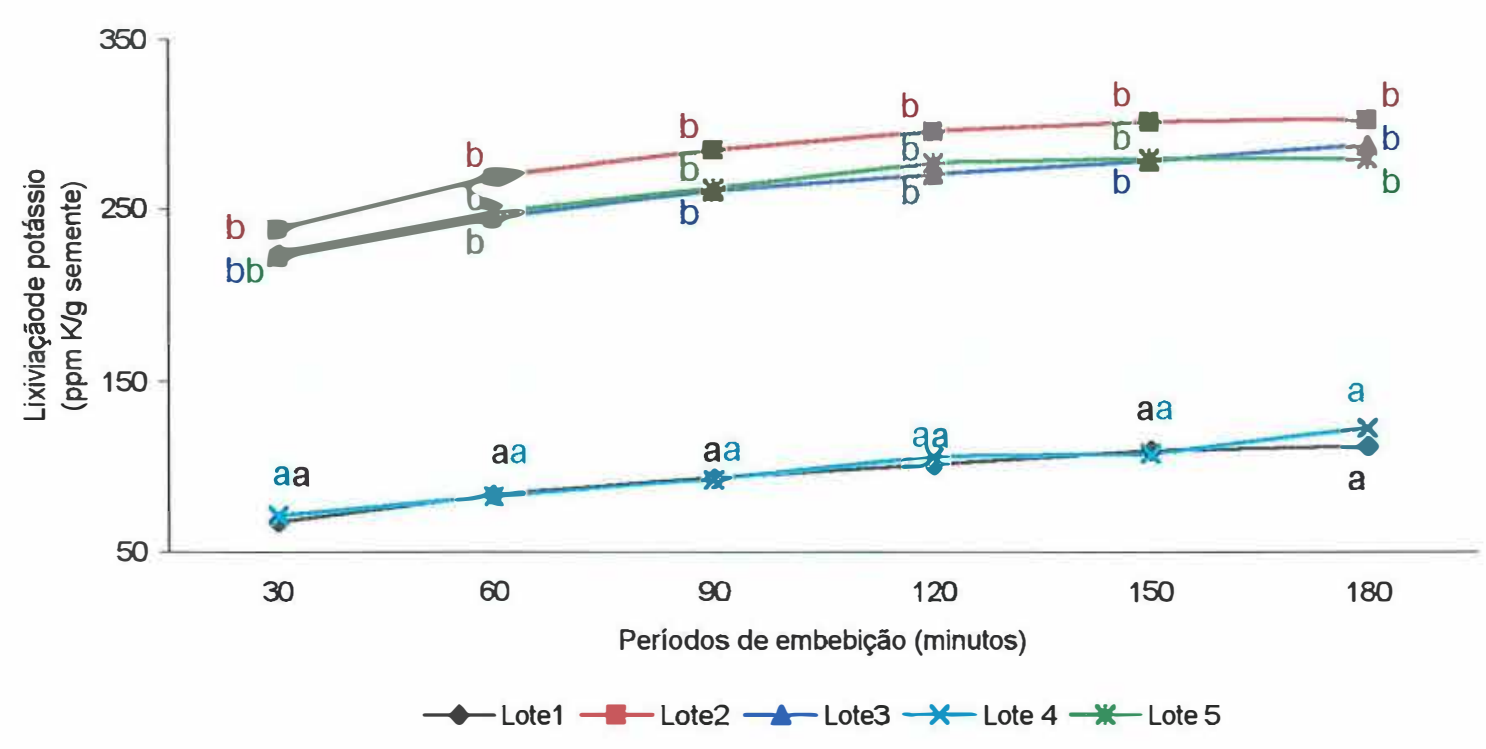

Figura 30. Híbrido Avant: comportamento dos cinco lotes de sementes, quanto à lixiviação de potássio, no tratamento 25 sementes $/ 25 \mathrm{ml} / 30^{\circ} \mathrm{C}$ (época 2).

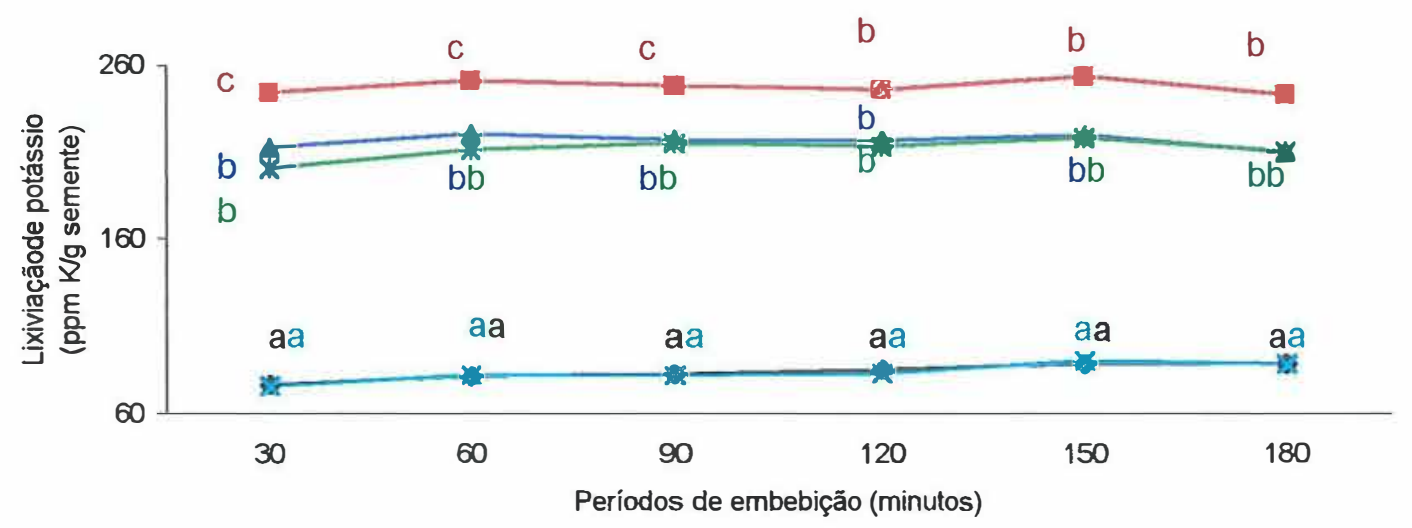

$\sim$ Lote $\rightarrow$ Lote $2 \longrightarrow$ Lote3 $\rightarrow$ Lote $4 \rightarrow x-$ Lote 5 
Assim, como a $25^{\circ} \mathrm{C}$ todos os tratamentos, de forma geral, foram eficientes na classificação dos lotes, de acordo com o potencial fisiológico das sementes. Os coeficientes de variação, apesar de serem maiores $(8,5 \%$ a $16,0 \%$ ) que a $25^{\circ} \mathrm{C}$, estavam dentro de um limite estatisticamente aceitável, para garantir a confiabilidade do teste.

\subsubsection{Híbrido AG 6690}

Diferentemente do híbrido Avant, a interação tratamentos $\mathrm{x}$ lotes não foi significativa em todos períodos de embebição estudados, ou seja, em determinados casos, os tratamentos não interferiram na classificação dos lotes. Nesses casos, os resultados foram representados por um valor médio da classificação dos lotes no período correspondente.

\subsubsection{Testes de lixiviação de potássio realizados a $25^{\circ} \mathrm{C}$}

Os resultados da lixiviação de potássio estão apresentados nas Tabelas 31 a 47. Observa-se na Figura 31, os períodos de 30, 150 e 180 minutos, na época 1, onde os tratamentos não interferiram na classificação dos lotes devido a não significância da interação tratamentos $x$ lotes. Observa-se que, coincidentemente, a classificação dos lotes, nos três períodos de embebição, foi a mesma e seguiu a tendência dos testes preliminares, identificando o lote 2 como superior e o 4 como inferior; no entanto, o lote 3 também foi identificado como superior, não diferindo estatisticamente do lote 2 , fato que não ocorreu nos testes preliminares de vigor.

Esse fato não ocorreu na época 2, onde todas as interações tratamentos $x$ lotes foram significativas, em todos os períodos de embebição.

As Figuras 32 a 47 representam os períodos de embebição, nos quais os tratamentos influenciaram na identificação de níveis diferentes de qualidade, entre os lotes. 
Observa-se que os lotes do híbrido AG 6690 não foram separados em grupos distintos (Figuras 31 a 47), como ocorreu no caso do híbrido Avant, fato que pode ter sido a causa de maiores variações na classificação dos lotes pelos diferentes tratamentos no híbrido Avant, quando comparado com o híbrido AG 6690. Apesar dos valores de lixiviação de potássio dos quatro lotes terem sido próximos, o teste foi eficiente na distinção de diferenças de qualidade entre eles.

Figura 31. Híbrido AG 6690: avaliação do potencial fisiológico de quatro lotes de sementes, quanto à lixiviação de potássio, nos tratamentos em que a interação tratamentos $\mathrm{x}$ lotes não foi significativa.

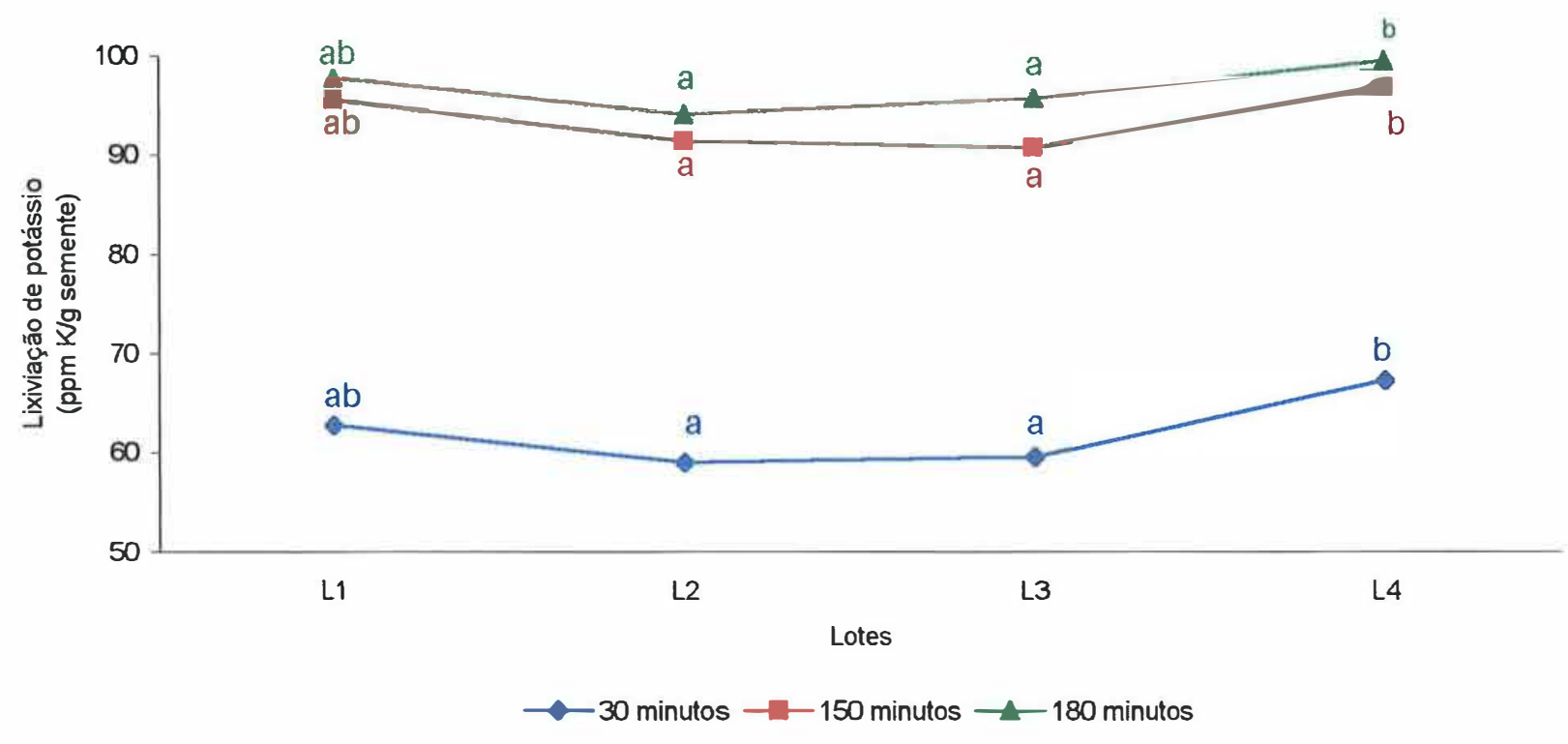

De maneira geral, os tratamentos estudados identificaram o lote 2 como superior e o lote 4 como inferior, havendo discordâncias nas posições dos lotes 1 e 3, que ocuparam posição superior, intermediária ou inferior em função do tratamento utilizado.

Portanto, o teste de lixiviação de potássio não foi consistente na deteç̧ão dos lotes que apresentavam qualidade intermediária. 
Figura 32. Híbrido AG 6690: avaliação do potencial fisiológico de quatro lotes de sementes, quanto à lixiviação de potássio, no tratamento 100 sementes/ $75 \mathrm{ml} / 25^{\circ} \mathrm{C}$ (época 1).

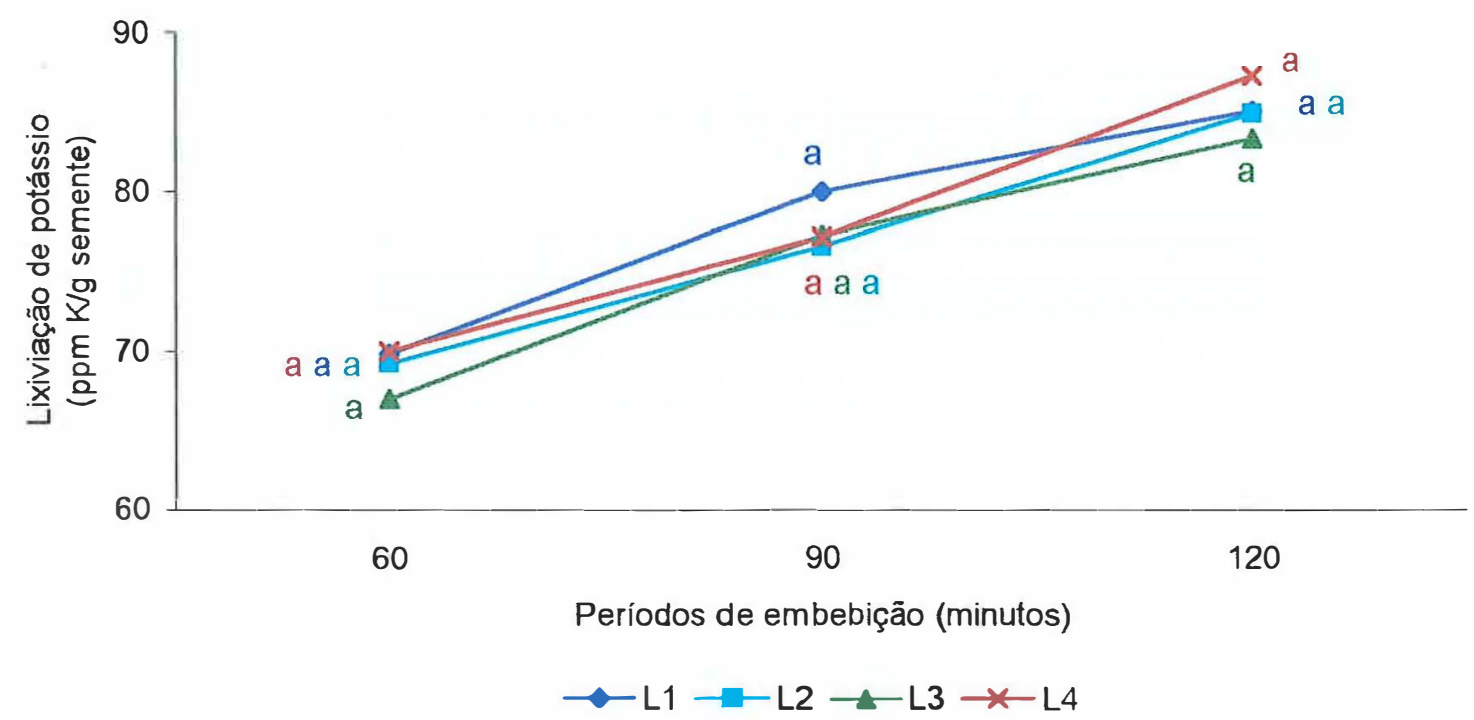

Figura 33. Híbrido AG 6690: Avaliação do potencial fisiológico de quatro lotes de sementes, quanto à lixiviação de potássio, no tratamento 100 sementes/ $50 \mathrm{ml} / 25^{\circ} \mathrm{C}$ (época 1 ).

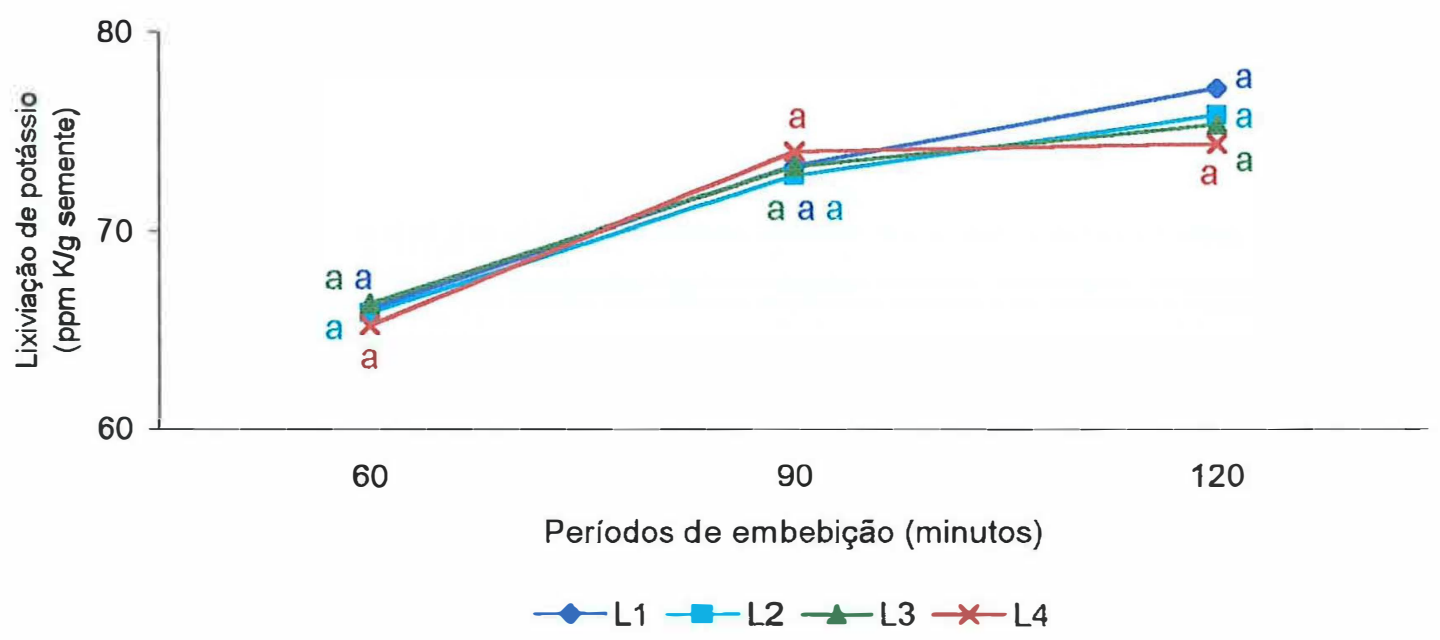


Figura 34. Híbrido AG 6690: avaliação do potencial fisiológico de quatro lotes de sementes, quanto à lixiviação de potássio, no tratamento 100 sementes/ $75 \mathrm{ml} / 25^{\circ} \mathrm{C}$ (época 2).

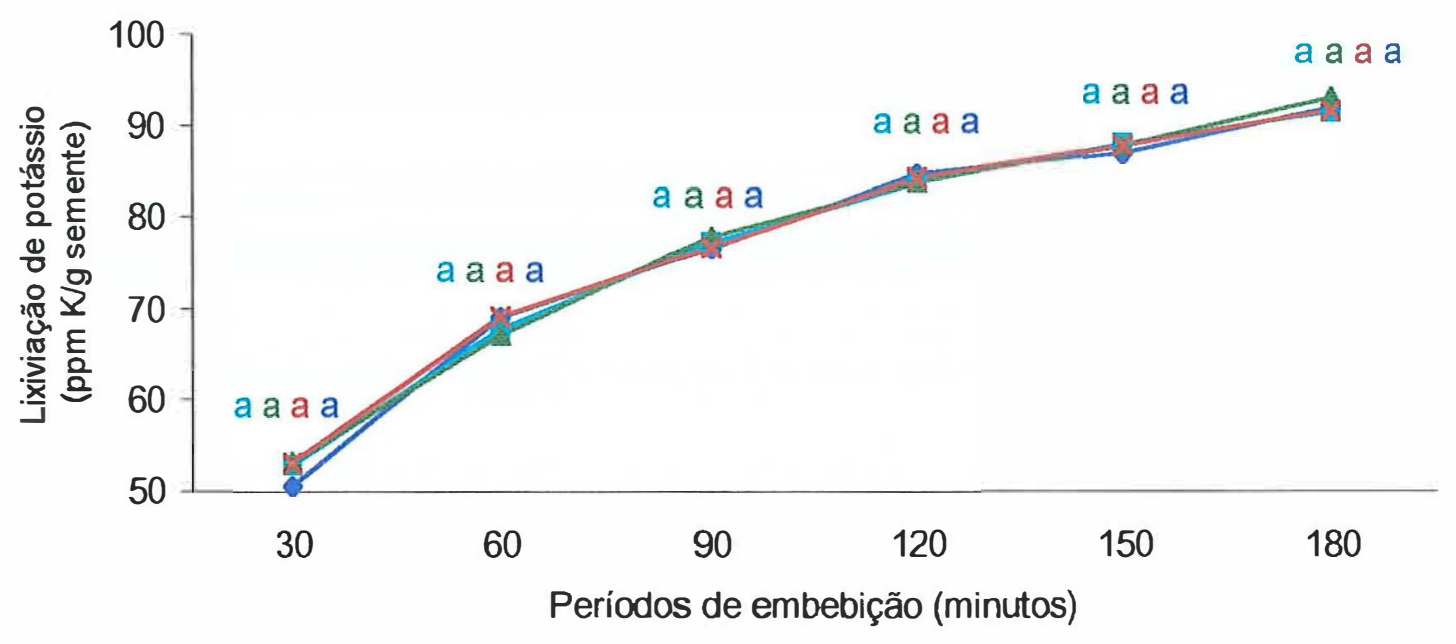$$
\rightarrow \mathrm{L} 1-\mathrm{L} 2 \rightarrow-\mathrm{L} 3 \rightarrow-\mathrm{L} 4
$$

Figura 35. Híbrido AG 6690: avaliação do potencial fisiológico de quatro lotes de sementes, quanto à lixiviação de potássio, no tratamento 100 sementes/ $50 \mathrm{ml} / 25^{\circ} \mathrm{C}$ (época 2).

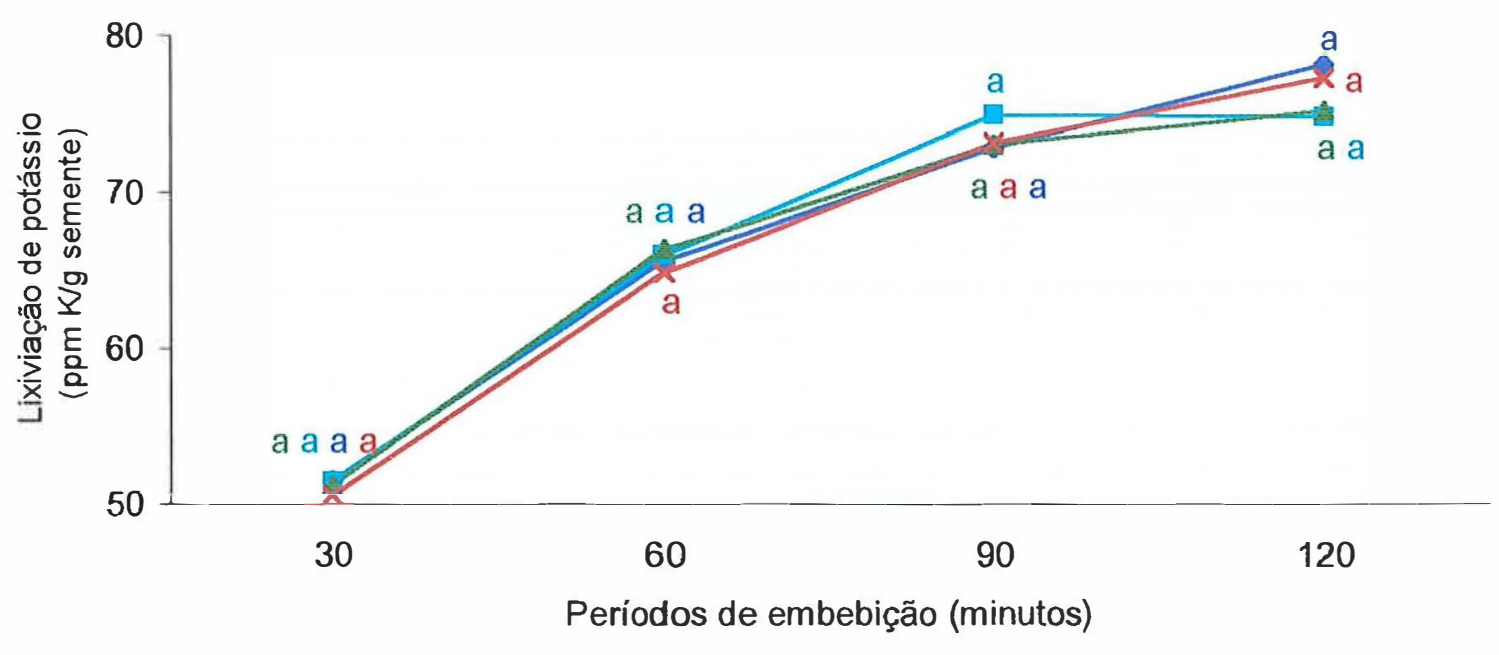

$\rightarrow \mathrm{L} 1 \rightarrow-\mathrm{L} 2 \rightarrow \mathrm{L} 3 \rightarrow-\mathrm{L} 4$ 
Figura 36. Híbrido AG 6690: avaliação do potencial fisiológico de quatro lotes de sementes, quanto à lixiviação de potássio, no tratamento 50 sementes/ $75 \mathrm{ml} / 25^{\circ} \mathrm{C}$ (época 1).

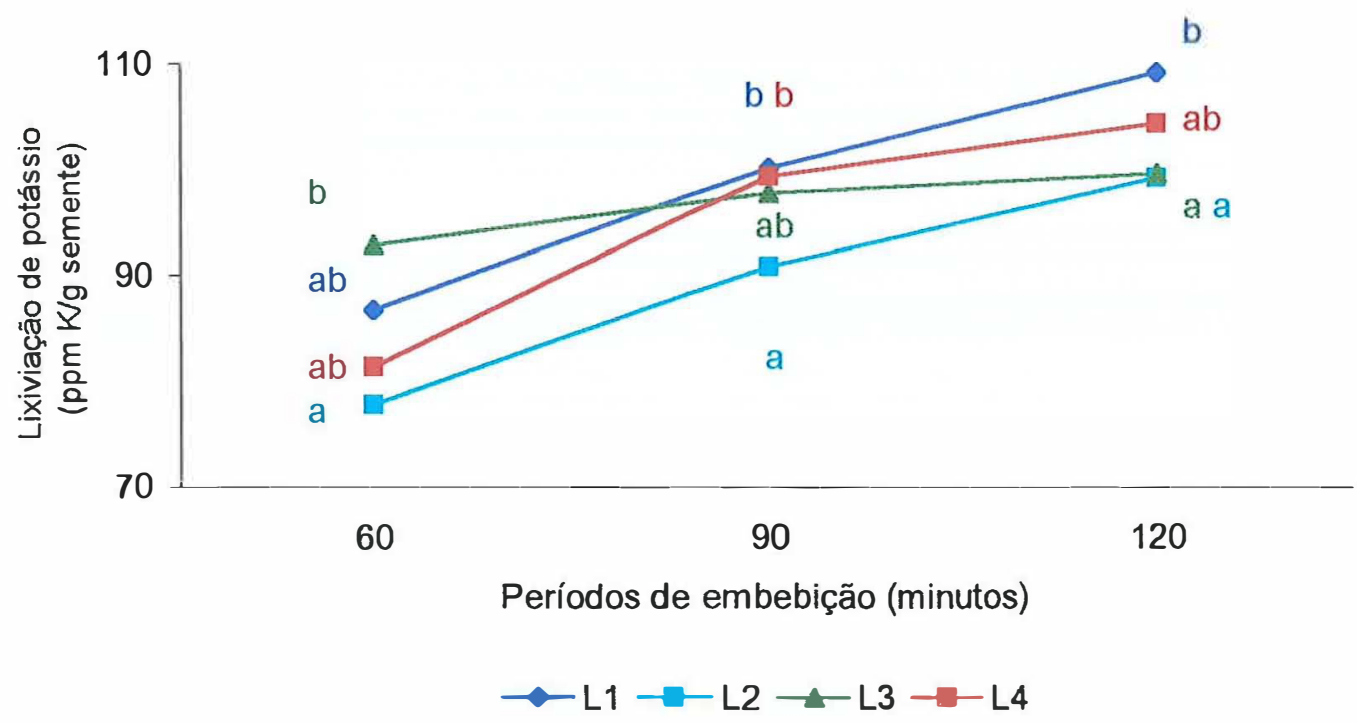

Figura 37. Híbrido AG 6690: avaliação do potencial fisiológico de quatro lotes de sementes, quanto à lixiviação de potássio, no tratamento 50 sementes/ $50 \mathrm{ml} / 25^{\circ} \mathrm{C}$ (época 1 ).

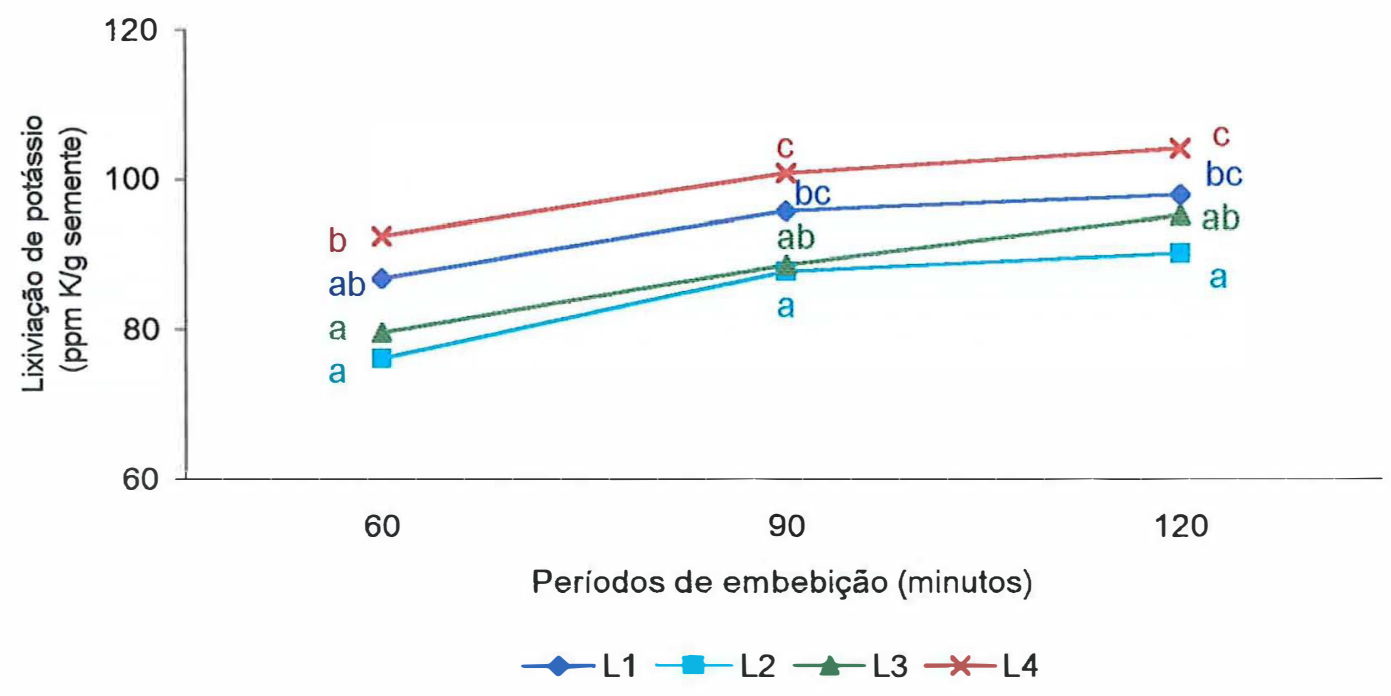


Figura 38. Híbrido AG 6690: avaliação do potencial fisiológico de quatro lotes de sementes, quanto à lixiviação de potássio, no tratamento 50 sementes/ $25 \mathrm{ml} / 25^{\circ} \mathrm{C}$ (época 1).

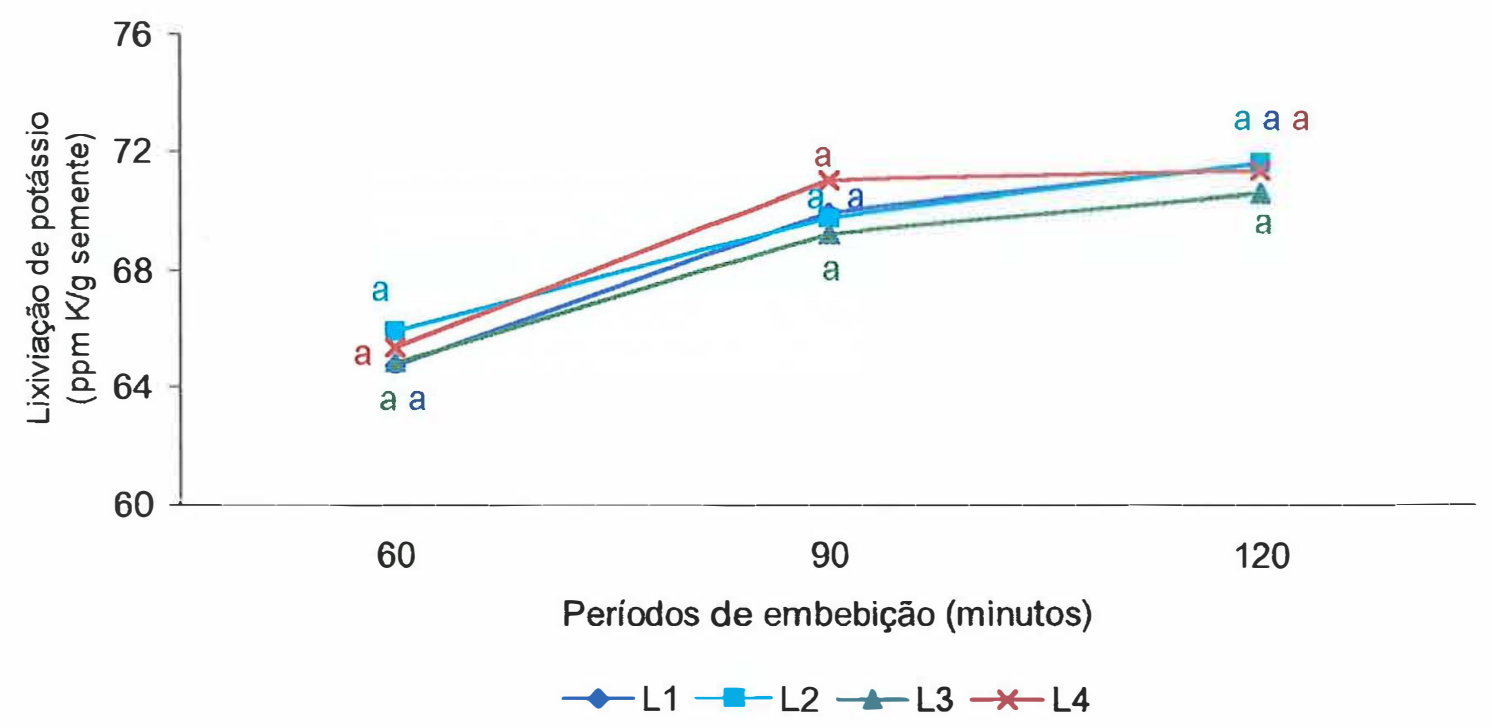

Figura 39. Híbrido AG 6690: avaliação do potencial fisiológico de quatro lotes de sementes, quanto à lixiviação de potássio, no tratamento 50 sementes/ $75 \mathrm{ml} / 25^{\circ} \mathrm{C}$ (época 2).

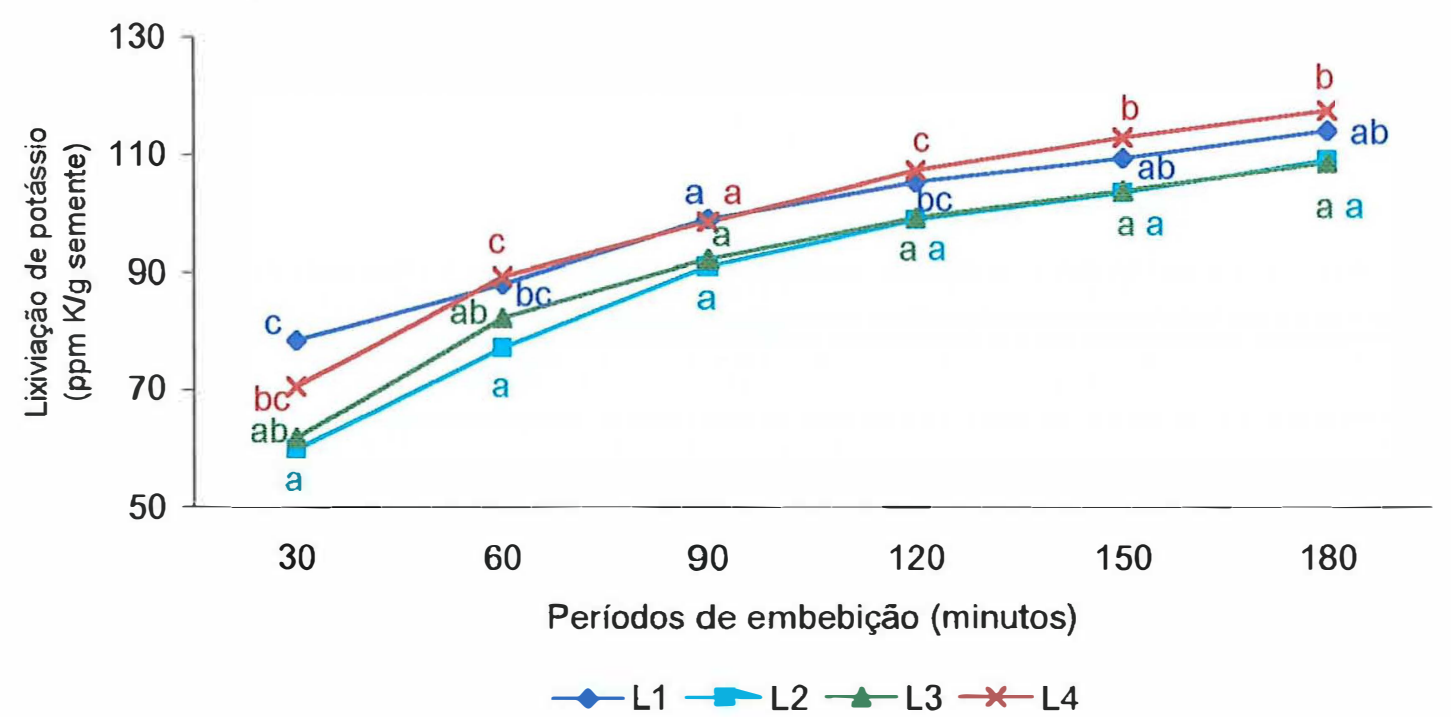


Figura 40. Híbrido AG 6690: avaliação do potencial fisiológico de quatro lotes de sementes, quanto à lixiviação de potássio, no tratamento 50 sementes/ $50 \mathrm{ml} / 25^{\circ} \mathrm{C}$ (época 2).

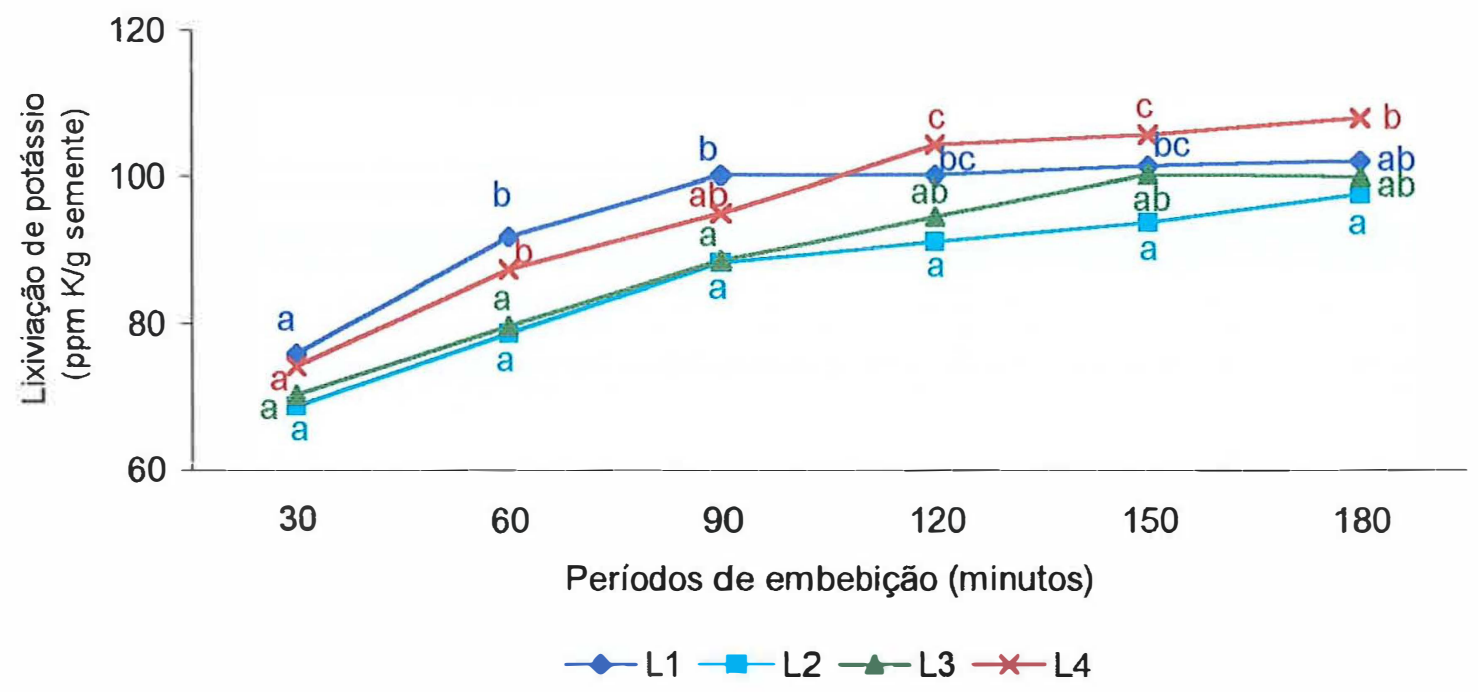

Figura 41. Híbrido AG 6690: avaliação do potencial fisiológico de quatro lotes de sementes, quanto à lixiviação de potássio, no tratamento 50 sementes/ $25 \mathrm{ml} / 25^{\circ} \mathrm{C}$ (época 2).

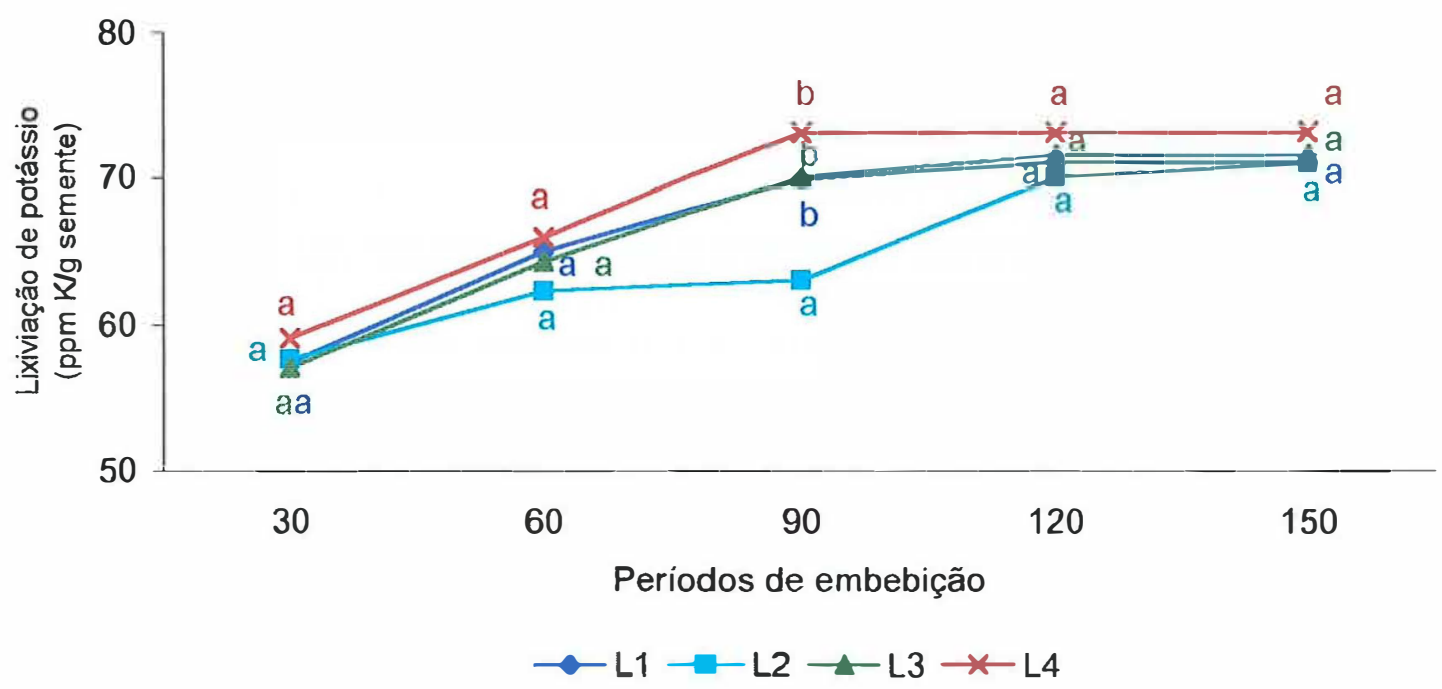


Figura 42. Híbrido AG 6690: avaliação do potencial fisiológico de quatro lotes de sementes, quanto à lixiviação de potássio, no tratamento 25 sementes/ $75 \mathrm{ml} / 25^{\circ} \mathrm{C}$ (época 1).

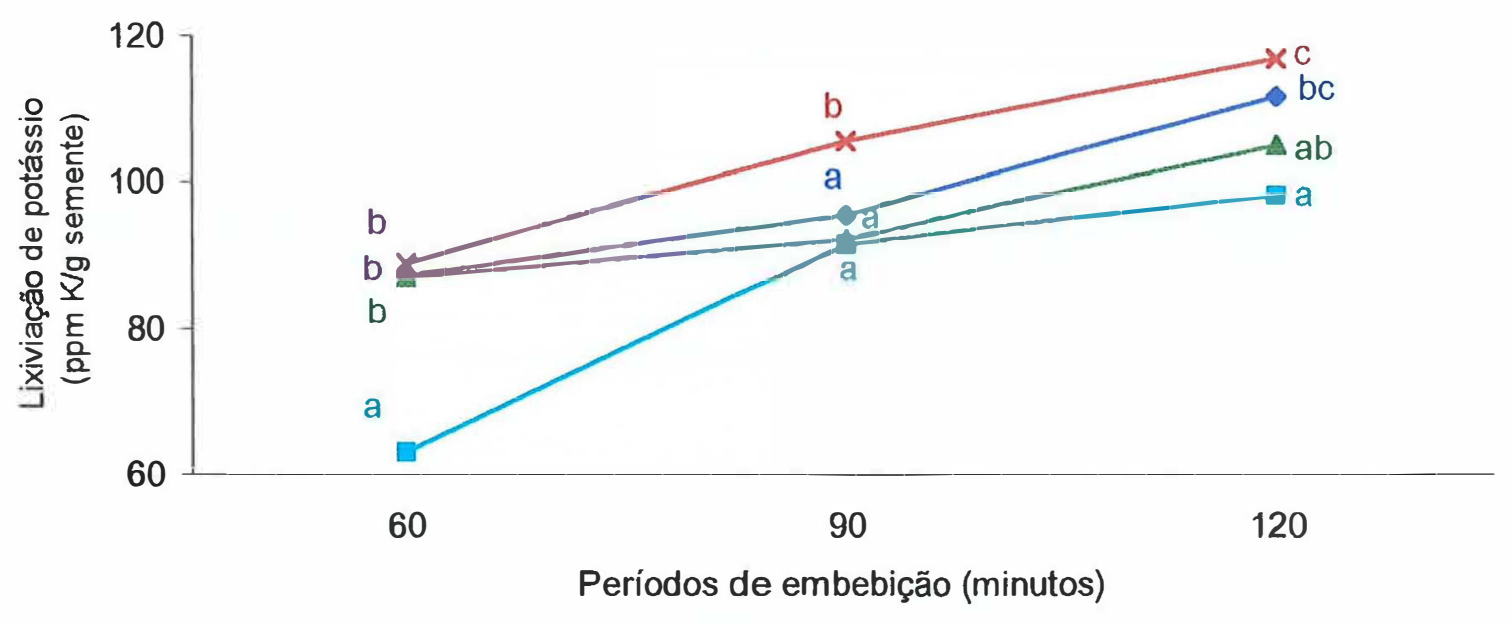

$\neg \mathrm{L} 1 \rightarrow-\mathrm{L} 2 \rightarrow \mathrm{L} 3 \rightarrow-\mathrm{L} 4$

Figura 43. Híbrido AG 6690: avaliação do potencial fisiológico de quatro lotes de sementes, quanto à lixiviação de potássio, no tratamento 25 sementes/ $50 \mathrm{ml} / 25^{\circ} \mathrm{C}$ (época 1).

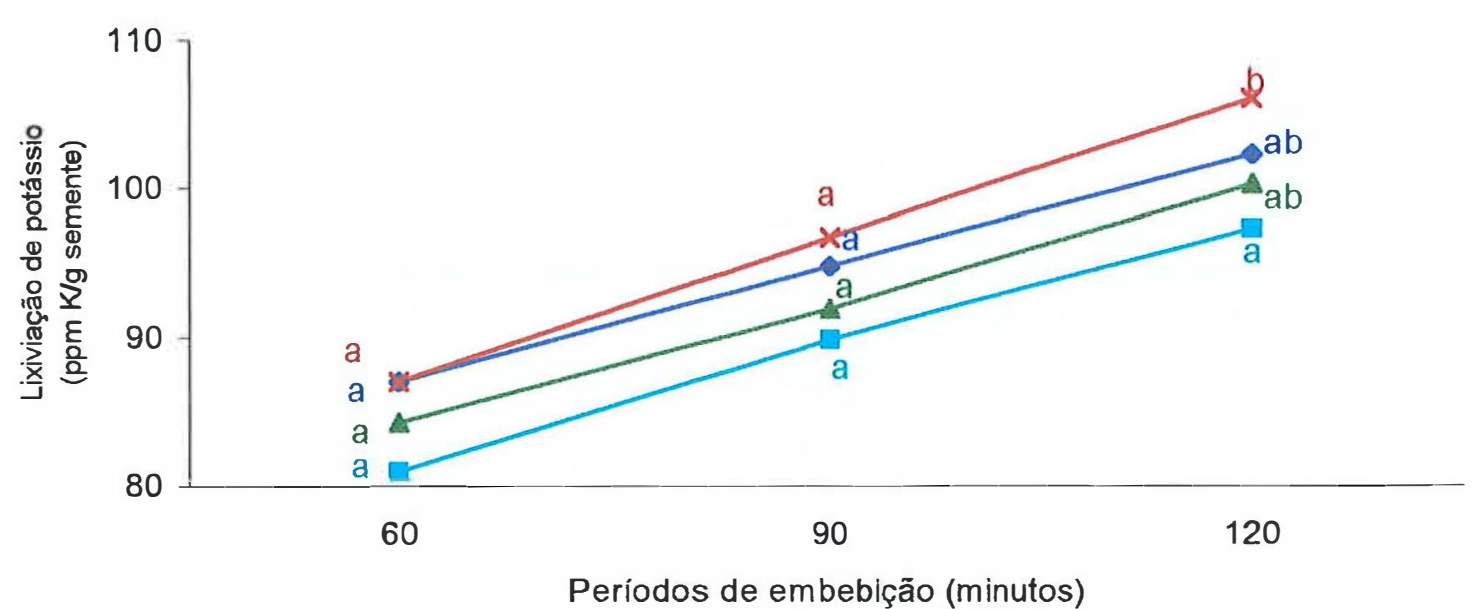

$\rightarrow \mathrm{L} 1 \rightarrow-\mathrm{L} 2 \rightarrow \mathrm{L} 3 \rightarrow-\mathrm{L} 4$ 
Figura 44. Híbrido AG 6690: avaliação do potencial fisiológico de quatro lotes de sementes, quanto à lixiviação de potássio, no tratamento 25 sementes/ $25 \mathrm{ml} / 25^{\circ} \mathrm{C}$ (época 1).

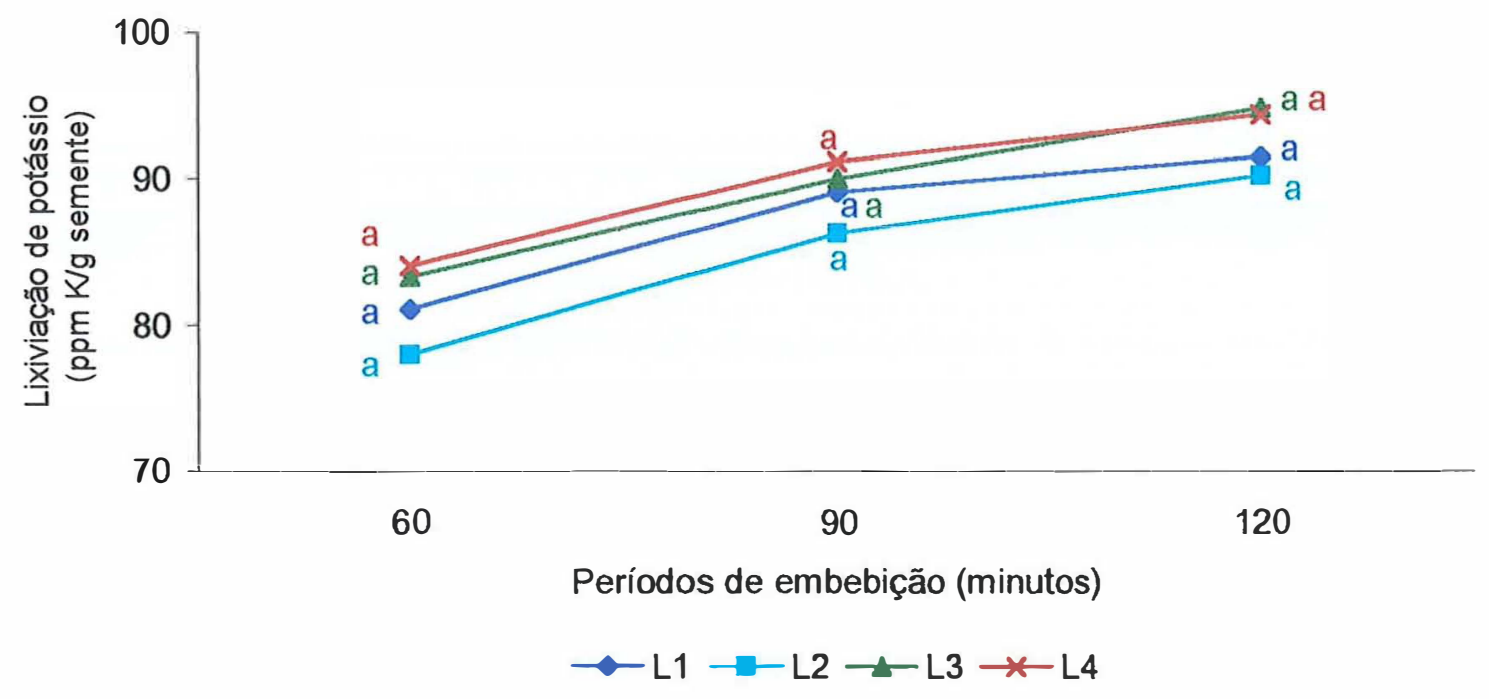

Figura 45. Híbrido AG 6690: avaliação do potencial fisiológico de quatro lotes de sementes, quanto à lixiviação de potássio, no tratamento 25 sementes/ $75 \mathrm{ml} / 25^{\circ} \mathrm{C}$ (época 2).

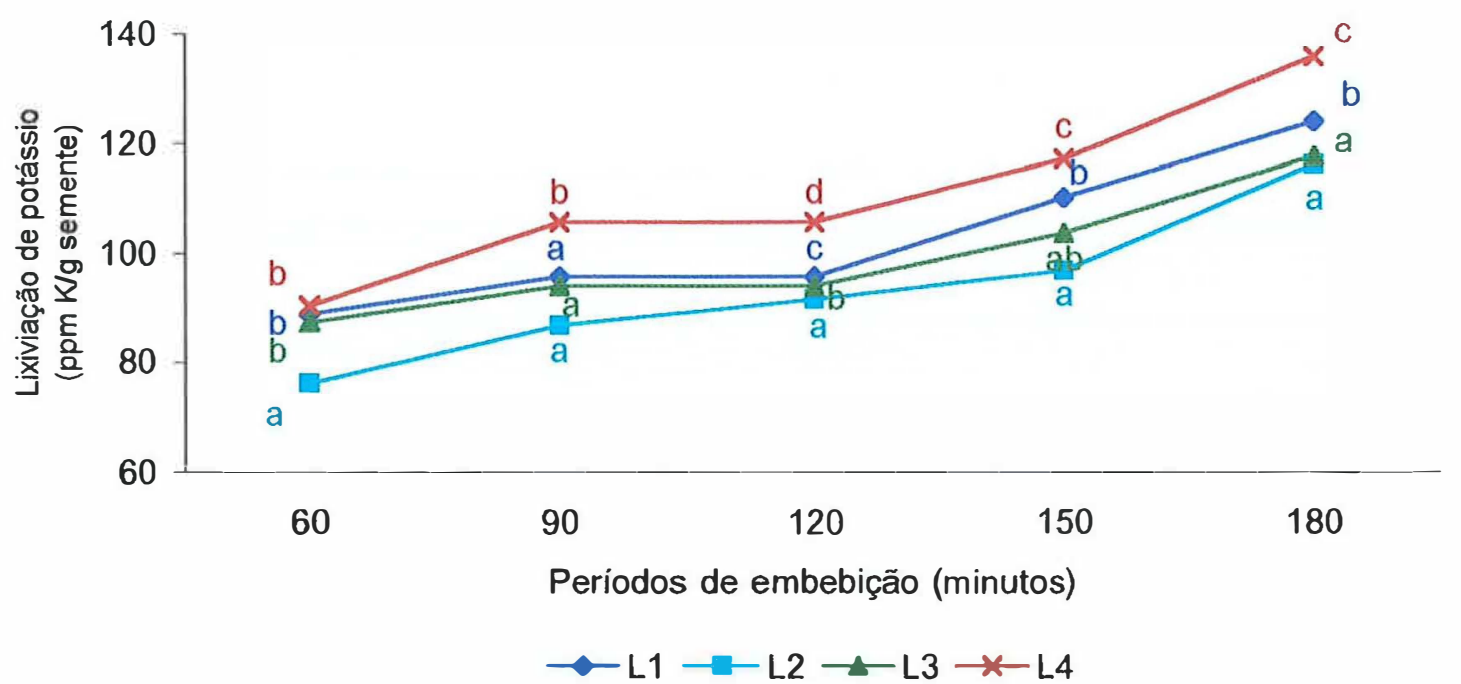


Figura 46. Híbrido AG 6690: avaliação do potencial fisiológico de quatro lotes de sementes, quanto à lixiviação de potássio, no tratamento 25 sementes/ $50 \mathrm{ml} / 25^{\circ} \mathrm{C}$ (época 1).

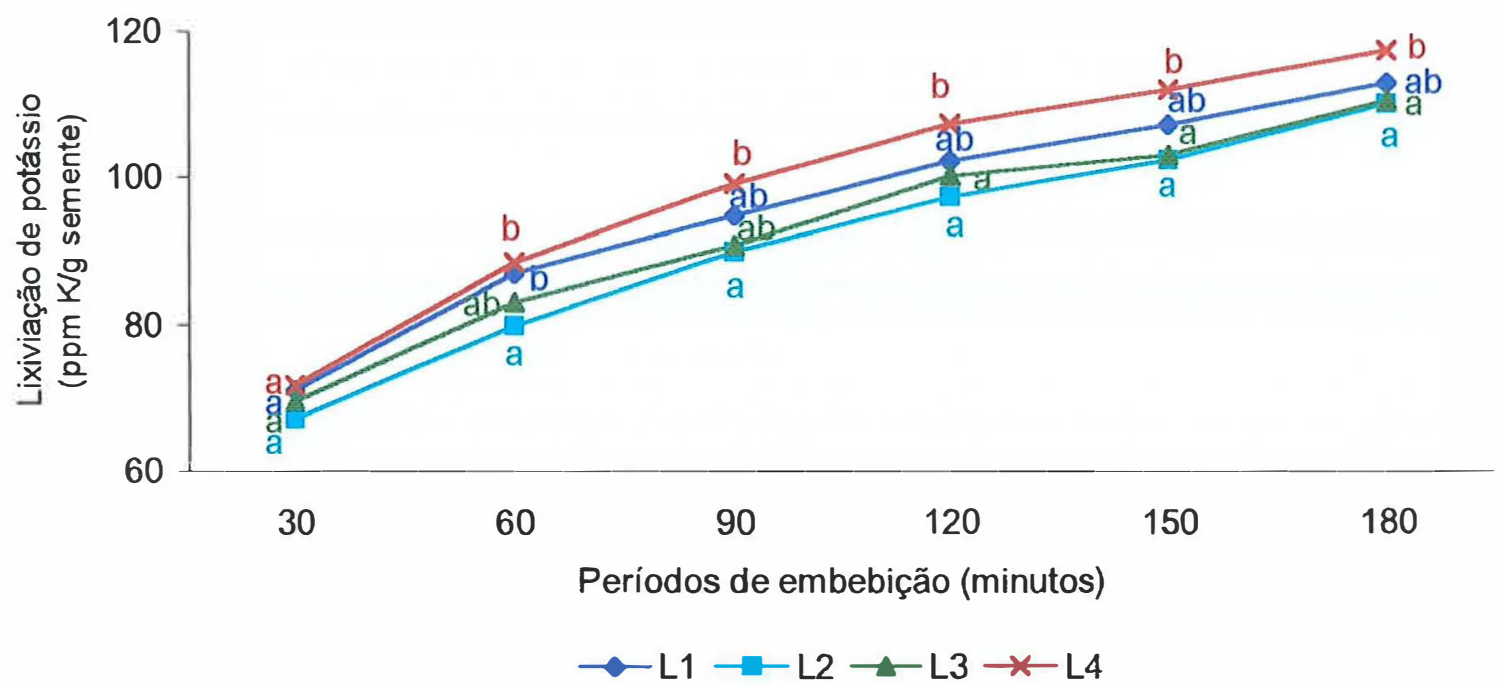

Figura 47. Híbrido AG 6690: avaliação do potencial fisiológico de quatro lotes de sementes, quanto à lixiviação de potássio, no tratamento 25 sementes/ $25 \mathrm{ml} / 25^{\circ} \mathrm{C}$ (época 2 ).

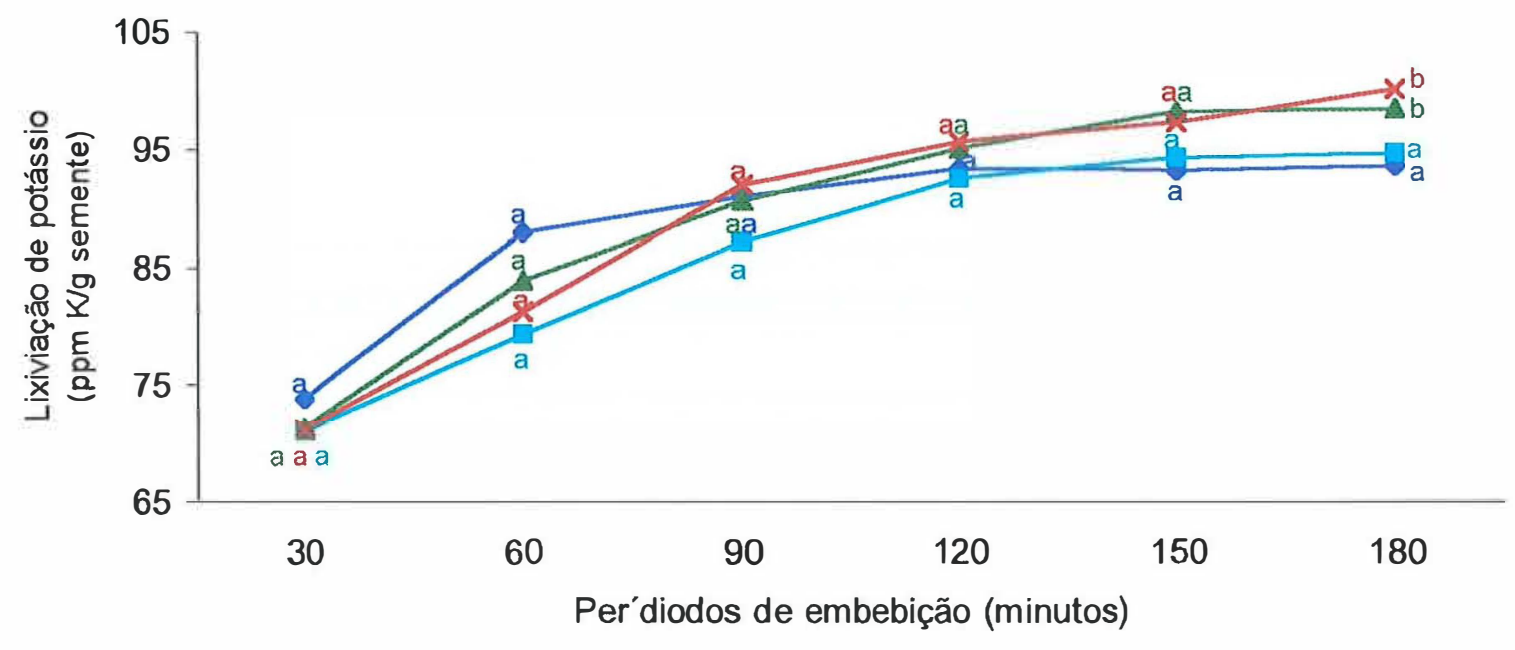

$\rightarrow \mathrm{L} 1 \rightarrow \mathrm{L} 2 \rightarrow-\mathrm{L} 3 \rightarrow-\mathrm{L} 4$ 
Esses resultados estão de acordo com os obtidos nas avaliações preliminares do potencial fisiológico dos lotes que, em geral, apontaram a superioridade do lote 2, a inferioridade do lote 4 e variações nas classificações dos lotes de qualidade intermediária (Figura 3).

Os tratamentos com 50 sementes $/ 75 \mathrm{ml}$ com 60 e 120 minutos de embebição, época 2 (Figura 39); 50 sementes $/ 50 \mathrm{ml}$ com 90 e 120 minutos de embebição na época 1(figura 37) e com 120, 150 e 180 minutos na época 2 (Figuras 40); 25 sementes/75ml com 120 minutos na época 1 (Figura 42) e com 120 e 150 na época 2 (Figura 45) e 25 sementes $/ 50 \mathrm{ml}$ com 90 minutos de embebição na época 2 (Figura 46), classificaram os lotes de maneira semelhante ao teste de condutividade elétrica indicando o lote 2 como superior, o lote 4 como inferior e os lotes 1 e 3 como intermediários.

Alguns tratamentos não foram eficientes na separação dos lotes de acordo com o potencial fisiológico das sementes, não detectando diferenças estatísticas entre eles, na maioria dos periodos de embebição (Figuras 32, 33, $34,35,38,40,41,43,44,46$ e 47). Esse fato não ocorreu com o híbrido Avant, uma vez que todos os tratamentos separaram os lotes de acordo com o vigor das sementes (Figuras 7 a 30); isto poderia ser explicado pela diferença mais acentuada entre o vigor dos lotes do híbrido Avant.

Para a determinação da quantidade de potássio lixiviado pelas sementes nos tratamentos de 100 sementes $/ 50 \mathrm{ml}$ e 50 sementes $/ 25 \mathrm{ml}$ com 150 e 180 minutos de embebição, nas épocas 1 e 2, foi necessária a diluição da solução de embebição; portanto, para que características como rapidez, praticidade e confiabilidade fossem mantidas no teste de lixiviação de potássio, esses tratamentos foram descartados.

Nos tratamentos de 25 sementes $/ 75 \mathrm{ml}$ com 30 minutos de embebição nas duas épocas, não foi possivel fazer as leituras, porque a quantidade de potássio exsudado pelas sementes não foi suficiente. Nesse caso seria necessário trabalhar com uma solução padrão com menor concentração de potássio. Entretanto, optou-se por utilizar apenas a solução de 50 ppm de 
potássio, visando a praticidade do teste, porque, ao ser alterado o padrão, o aparelho teria que ser calibrado novamente. Além disso, não é possível saber a qualidade da semente antes de analisá-la; portanto, é recomendável o uso de um padrão que permita leituras e sem a necessidade de diluição (Carvalho et al., 1999).

Os coeficientes de variação dos tratamentos, dentro de cada período de embebição, foram baixos, variando de $3,4 \%$ a $11,9 \%$.

\subsubsection{Testes de lixiviação de potássio realizados a $30^{\circ} \mathrm{C}$}

Os resultados dos testes realizados na temperatura de $30^{\circ} \mathrm{C}$ encontram-se nas Figuras 48 a 57 . Nas Figuras 48 e 49 estão representados os valores médios da lixiviação de potássio dos lotes, nos períodos em que a interação tratamentos $x$ lotes não foi significativa, nas épocas 1 e 2 , respectivamente.

Nota-se que, na época 1(Figura 48) apenas nos períodos de 30 e 150 minutos de embebição os tratamentos influenciaram a classificação dos lotes (Figuras 50 a 57).

$\mathrm{Na}$ época 2 (Figura 49) diferentemente da época1 (Figura 48), os tratamentos não interferiram na classificação dos lotes em nenhum período de embebição. Apenas no período de 180 minutos o teste foi eficiente na detecção de diferenças de qualidade entre os lotes. No entanto, houve distinção apenas do lote 2, que teve desempenho superior; os lotes 1, 3 e 4 foram classificados como inferiores, não havendo posições intermediárias. 
Figura 48. Híbrido AG 6690: avaliação do potencial fisiológico de quatro lotes de sementes, quanto à lixiviação de potássio, nos tratamentos em que a interação tratamentos $\mathrm{x}$ lotes não foi significativa, na época 1.

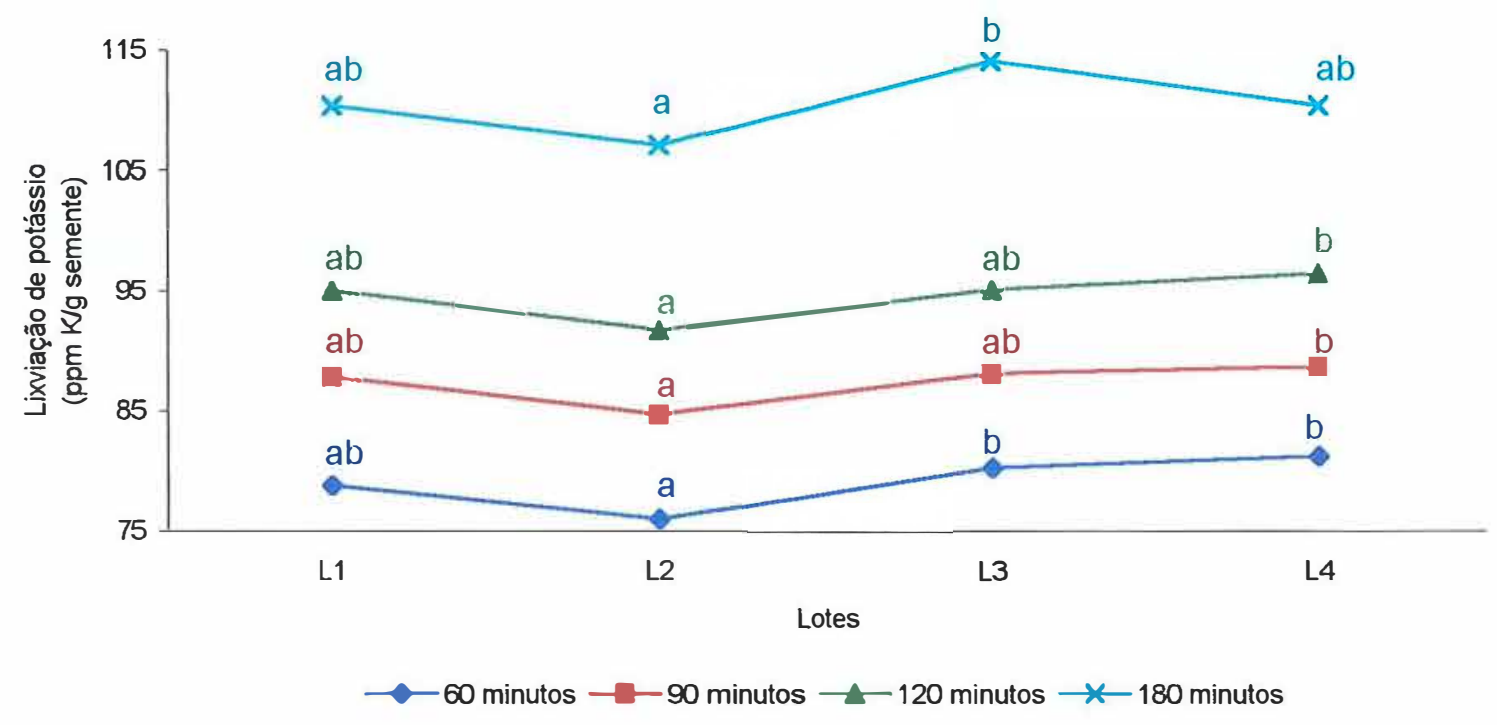

Figura 49. Híbrido AG 6690: avaliação do potencial fisiológico de quatro lotes de sementes, quanto à lixiviação de potássio, nos tratamentos em que a interação tratamentos x lotes não foi significativa, na época 2.

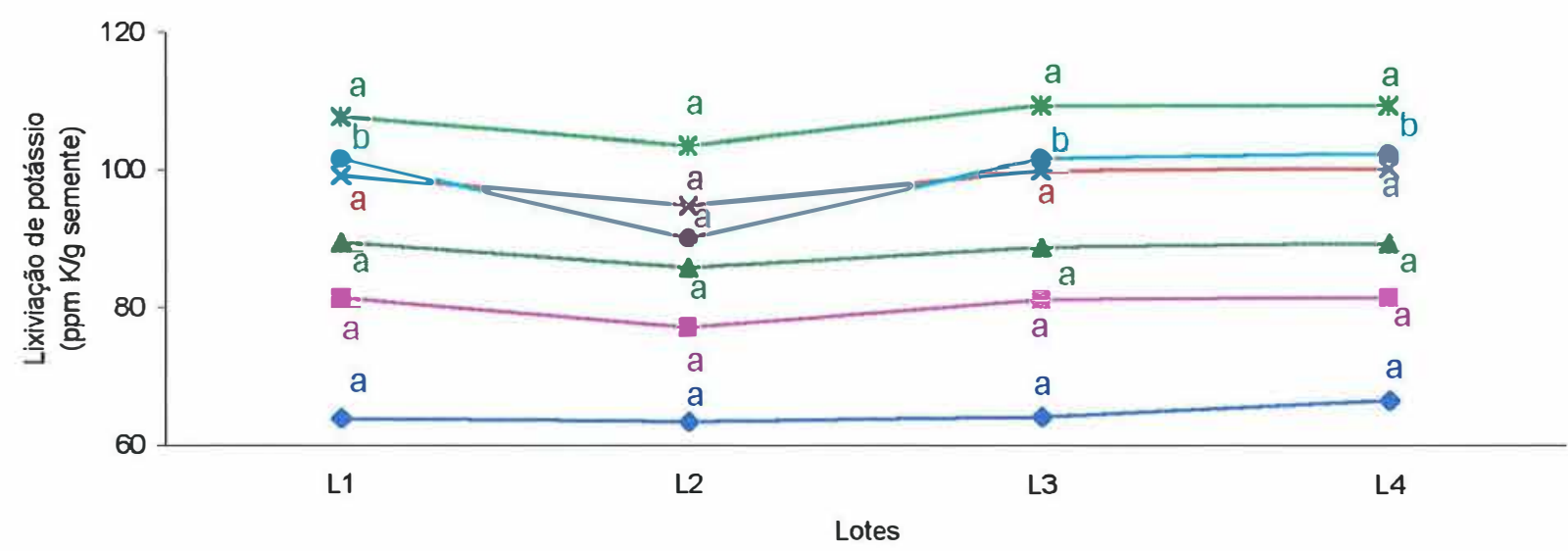

$\smile 30$ minutos $\neg-60$ minutos $\neg-90$ minutos $\rightarrow-120$ minutos $\rightarrow-150$ minutos $\longrightarrow 180$ minutos 
As Figuras 50 a 57 contem os resultados dos tratamentos que interferiram na classificação dos lotes, na época 1.

Figura 50. Híbrido AG 6690: avaliação do potencial fisiológico de quatro lotes de sementes, quanto à lixiviação de potássio, no tratamento 100 sementes/ $75 \mathrm{ml} / 30^{\circ} \mathrm{C}$ (época 1 ).
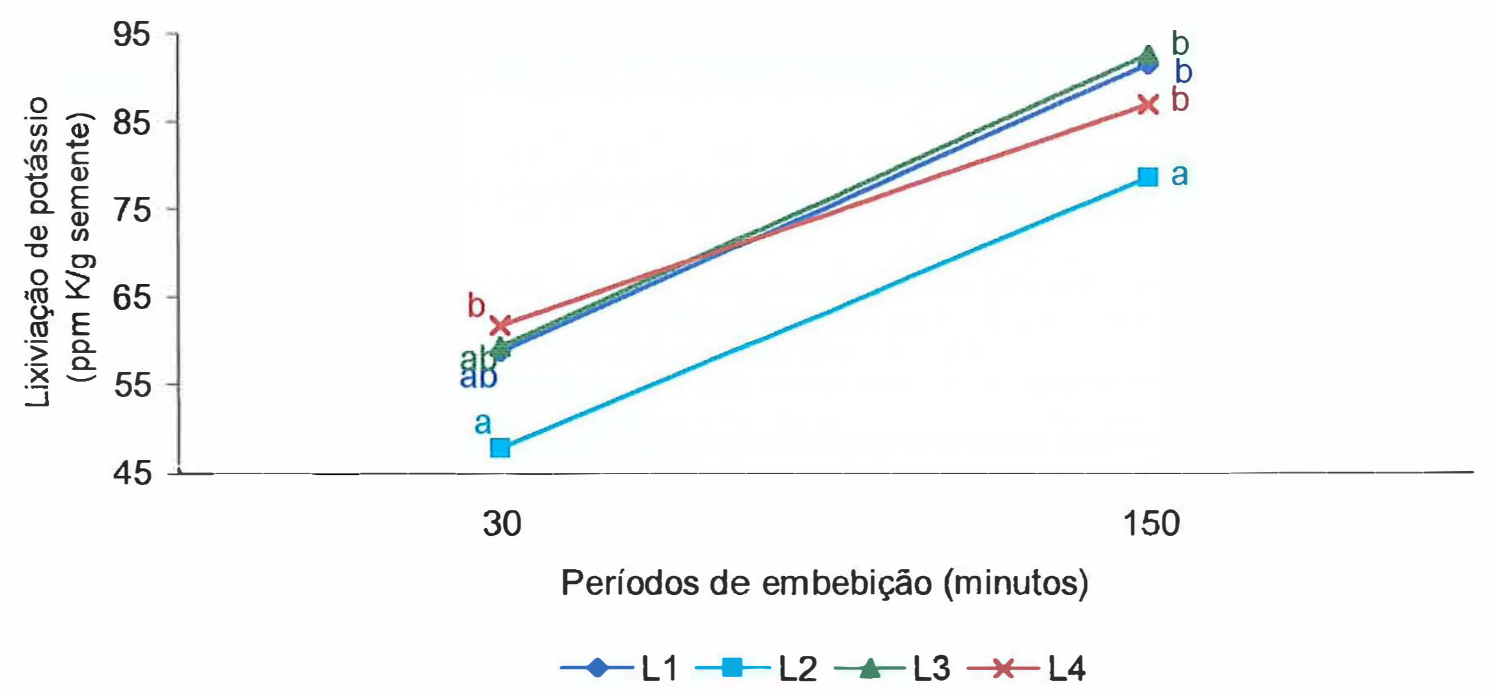

Figura 51. Híbrido AG 6690: avaliação do potencial fisiológico de quatro lotes de sementes, quanto à lixiviação de potássio, no tratamento 100 sementes/ $50 \mathrm{ml} / 30^{\circ} \mathrm{C}$ (época 1).

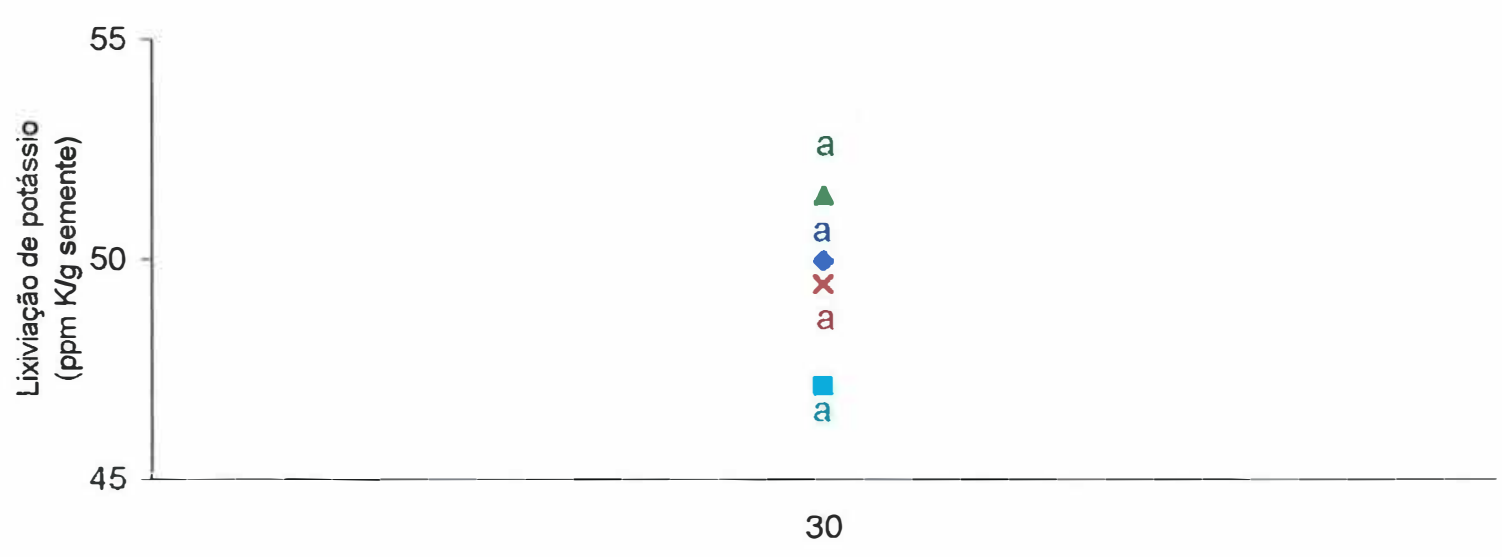

Períodos de embebição (minutos) 
Figura 52. Híbrido AG 6690: avaliação do potencial fisiológico de quatro lotes de sementes, quanto à lixiviação de potássio, no tratamento 50 sementes/ $75 \mathrm{ml} / 30^{\circ} \mathrm{C}$ (época 1).

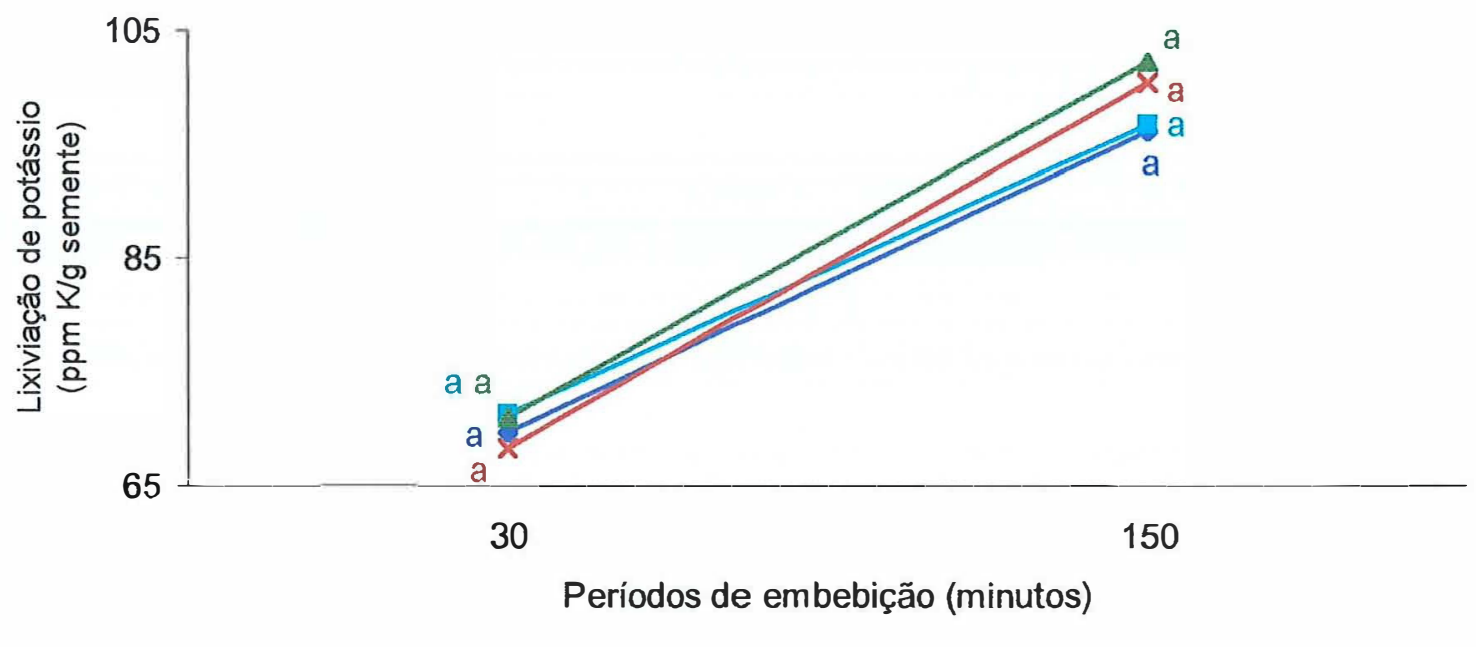

$\rightarrow \mathrm{L} 1 \rightarrow-\mathrm{L} 2 \rightarrow-\mathrm{L} 3 \rightarrow-\mathrm{L} 4$

Figura 53. Híbrido AG 6690: avaliação do potencial fisiológico de quatro lotes de sementes, quanto à lixiviação de potássio, no tratamento 50 sementes/ $50 \mathrm{ml} / 30^{\circ} \mathrm{C}$ (época 1).

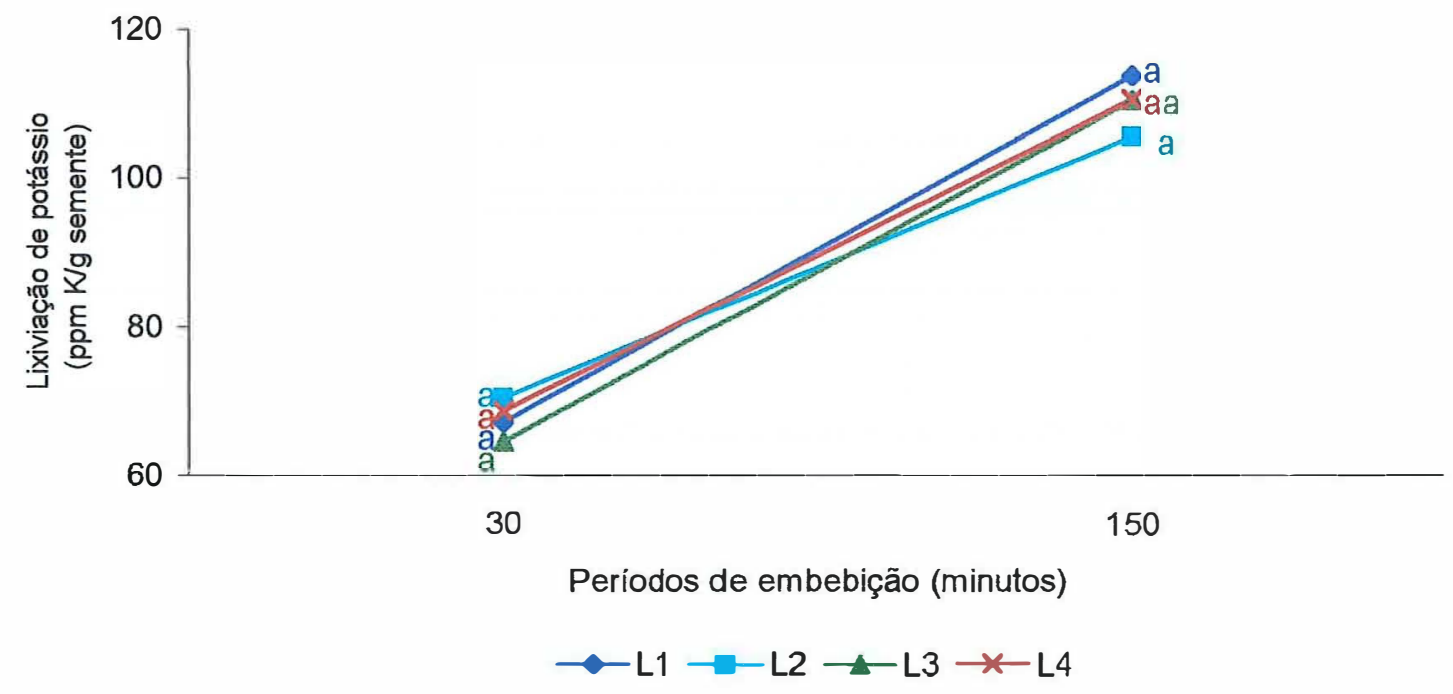


Figura 54. Híbrido AG 6690: avaliação do potencial fisiológico de quatro lotes de sementes, quanto à lixiviação de potássio, no tratamento 50 sementes/ $25 \mathrm{ml} / 30^{\circ} \mathrm{C}$ (época 1$)$.

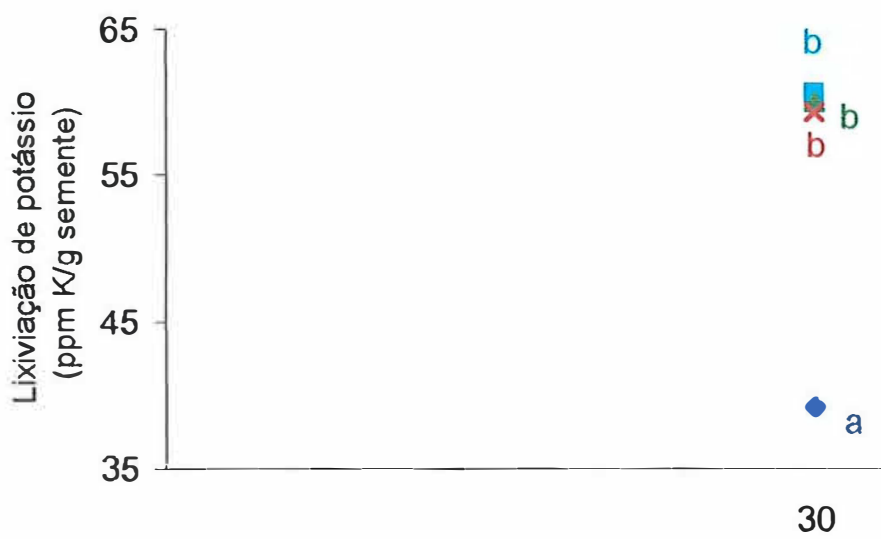

Períodos de embebição (minutos)

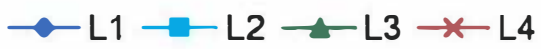

Figura 55. Híbrido AG 6690: avaliação do potencial fisiológico de quatro lotes de sementes, quanto à lixiviação de potássio, no tratamento 25 sementes/ $75 \mathrm{ml} / 30^{\circ} \mathrm{C}$ (época 1).

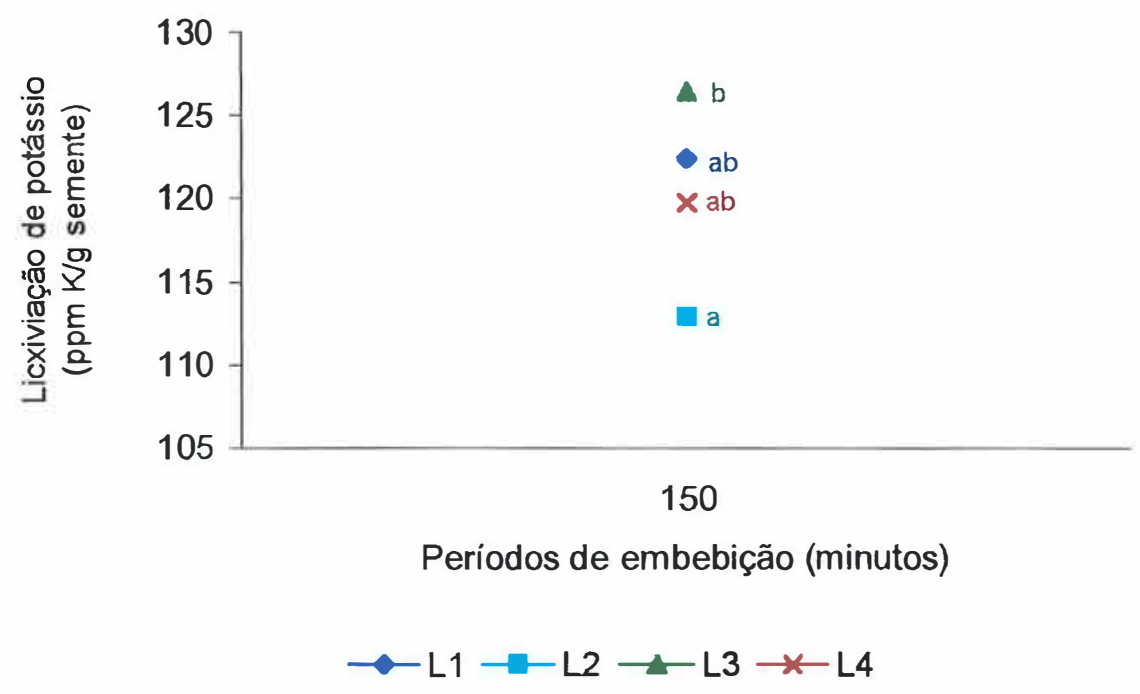


Figura 56. Híbrido AG 6690: avaliação do potencial fisiológico de quatro lotes de sementes, quanto à lixiviação de potássio, no tratamento 25 sementes/ $50 \mathrm{ml} / 30^{\circ} \mathrm{C}$ (época 1).

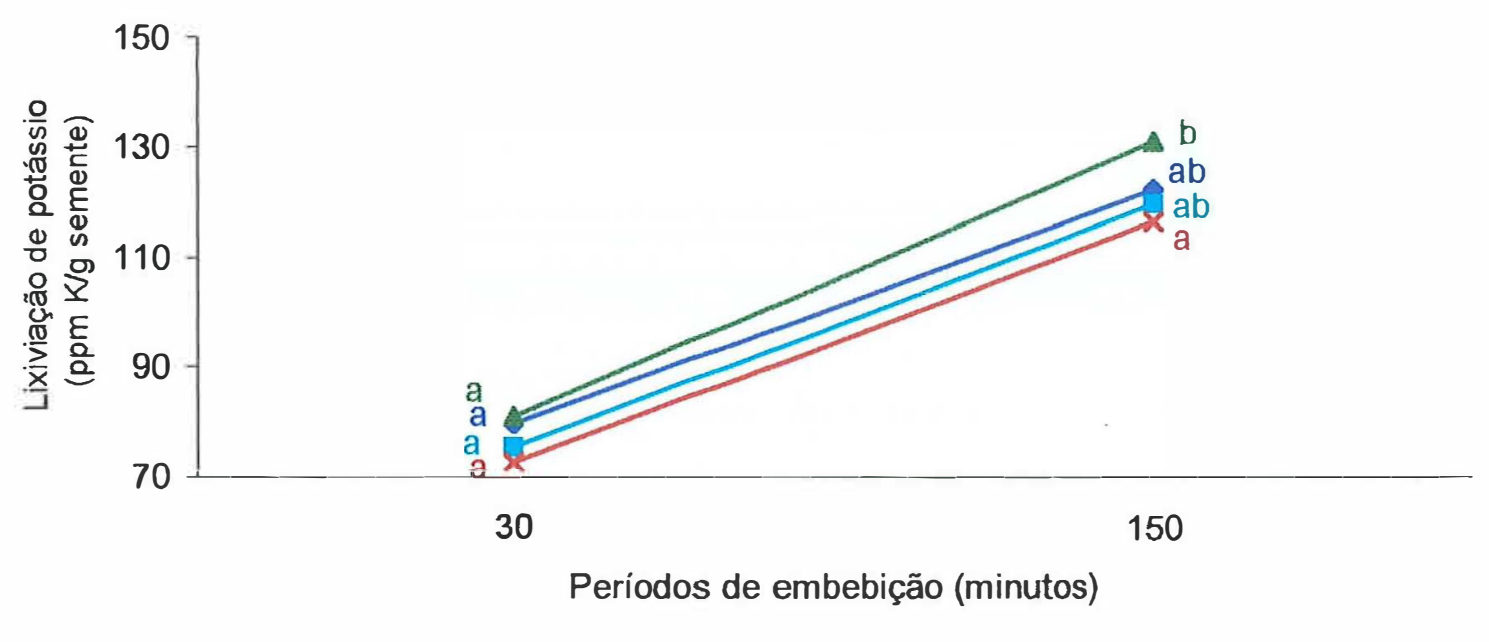

$\rightarrow \mathrm{L} 1 \rightarrow-\mathrm{L} 2 \rightarrow-\mathrm{L} 3 \rightarrow x-\mathrm{L} 4$

Figura 57. Híbrido AG 6690: avaliação do potencial fisiológico de quatro lotes de sementes, quanto à lixiviação de potássio, no tratamento 25 sementes/ $25 \mathrm{ml} / 30^{\circ} \mathrm{C}$ (época 1).

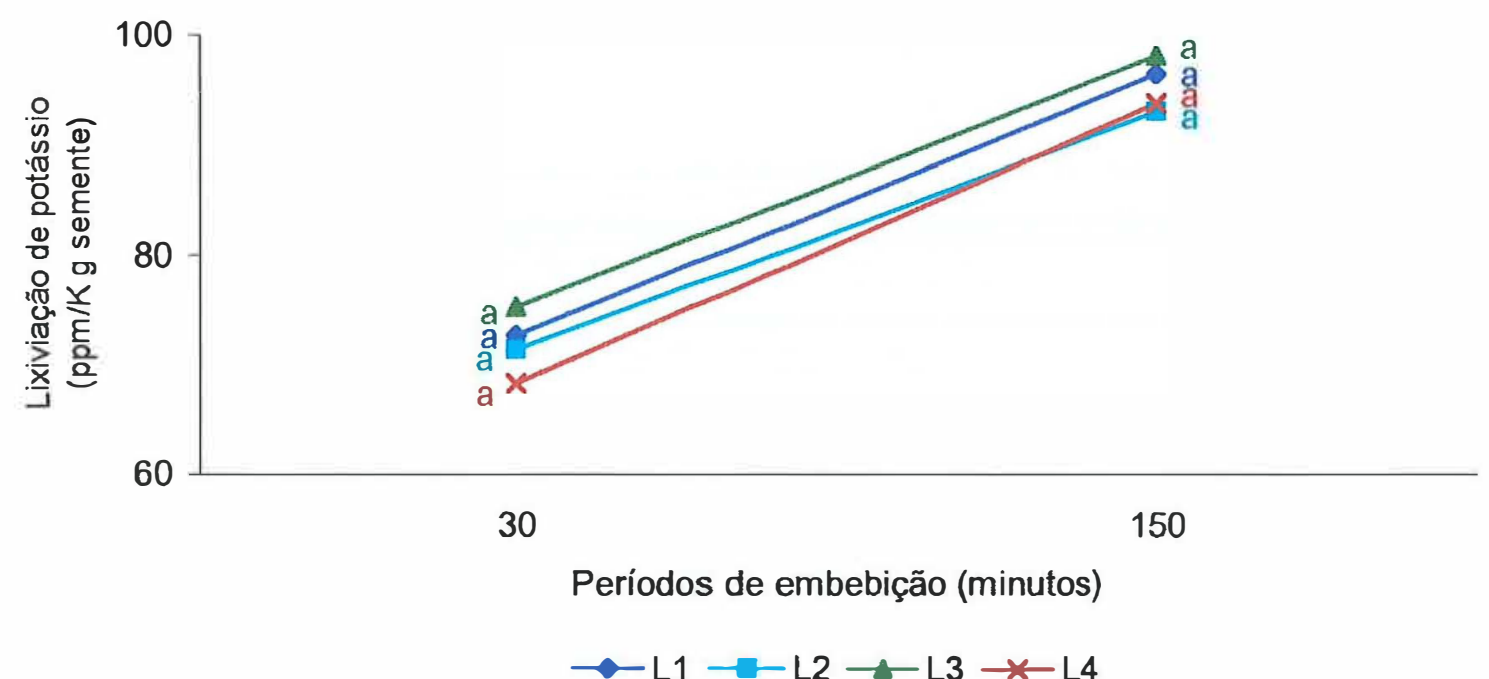


A maioria dos tratamentos a $30^{\circ} \mathrm{C}$ (Figuras 48 a 57) não detectou diferenças de qualidade entre os lotes, tanto na época 1 como na época 2 . No entanto, os tratamentos que distinguiram os lotes de acordo com o potencial fisiológico, o fizeram de maneira semelhante aos testes preliminares, ou seja, o lote 2 foi identificado como superior, o lote 4 como inferior e os lotes 1 e 3 ocuparam posição intermediária, na maioria dos casos.

A reprodutibilidade dos dados entre as duas épocas foi baixa, havendo coincidências apenas entre os tratamentos que não conseguiram identificar a qualidade dos lotes.

A necessidade de diluição ocorreu nos tratamentos de 100 sementes $/ 50 \mathrm{ml}$ e de 50 sementes $/ 25 \mathrm{ml}$ com 150 e 180 minutos de embebição nas épocas 1 e 2. Pelos mesmos motivos mencionados anteriormente, esses tratamentos foram descartados. A leitura de lixiviação de potássio no tratamento de 25 sementes/75 ml com 30 minutos de embebição, na época 2, não foi feita porque a quantidade de potássio lixiviado pelas sementes de milho foi insuficiente.

Como no híbrido Avant, os coeficientes de variação foram maiores a $30^{\circ} \mathrm{C}(6,4 \%$ a $14,5 \%)$ mas, ficaram dentro de um limite aceitável, demonstrando a confiabilidade do teste de lixiviação de potássio.

\subsubsection{Híbrido Traktor}

Para o híbrido Traktor a interação tratamentos $\mathrm{x}$ lotes foi significativa apenas na época 2 , tanto a $25^{\circ} \mathrm{C}$ como a $30^{\circ} \mathrm{C}$. Dessa forma, na época 1 , independentemente do tratamento estudado, a classificação dos lotes foi a mesma, dentro de um mesmo período de embebição.

\subsubsection{Testes de lixiviação de potássio realizados a $25^{\circ} \mathrm{C}$}

Os resultados da lixiviação das sementes de milho nos diferentes tratamentos estão nas Figuras 58 a 65. A figura 58 contem a representação do 
valor médio da lixiviação dos cinco lotes, nos diferentes tratamentos e períodos de embebição, na época 1, uma vez que não houve interação significativa entre tratamentos e lotes e, as Figuras 59 a 65 trazem os resultados dos períodos em que a interação tratamentos $x$ lotes foi significativa.

Verifica-se que, de maneira geral, os tratamentos, que detectaram diferenças de qualidade entre os lotes, foram consistentes na identificação do lote 4 como superior aos demais, de acordo com o potencial fisiológico das sementes. Assim, os tratamentos do teste de lixiviação de potássio, foram eficientes na separação do lote de qualidade superior, ao contrário do que ocorreu nos testes das avaliações preliminares, onde houve apenas uma tendência dessa identificação.

No entanto, o lote 3 , classificado como de menor qualidade, entre os lotes estudados, pelos testes de vigor, nem sempre foi considerado inferior pelos testes de lixiviação de potássio. A Figura 64 mostra tratamentos que foram exceções e apontaram a inferioridade do lote 3 , em relação aos outros lotes avaliados; essa classificação foi a mesma fornecida pelos testes de condutividade elétrica e envelhecimento acelerado nas avaliações preliminares.

Alguns tratamentos, assim como os testes de frio e de emergência de plântulas em campo, não identificaram diferenças estatísticas entre o potencial fisiológico dos cinco lotes como pode ser observado nas Figuras 59, 60, 61, 62, 63 e 65. Esse fato, não pode ser apenas atribuído a um periodo insuficiente de embebição, pois em alguns casos como no tratamento de 50 sementes $/ 50 \mathrm{ml}$, na época 2 (Figura 62), os lotes foram separados em niveis de vigor com 30 minutos de embebição, o que não aconteceu nos períodos de 60 e 90 minutos de embebição (Figura 62). 
Figura 58. Híbrido Traktor: avaliação do potencial fisiológico de cinco lotes de sementes, quanto a lixiviação de potássio, na época 1.

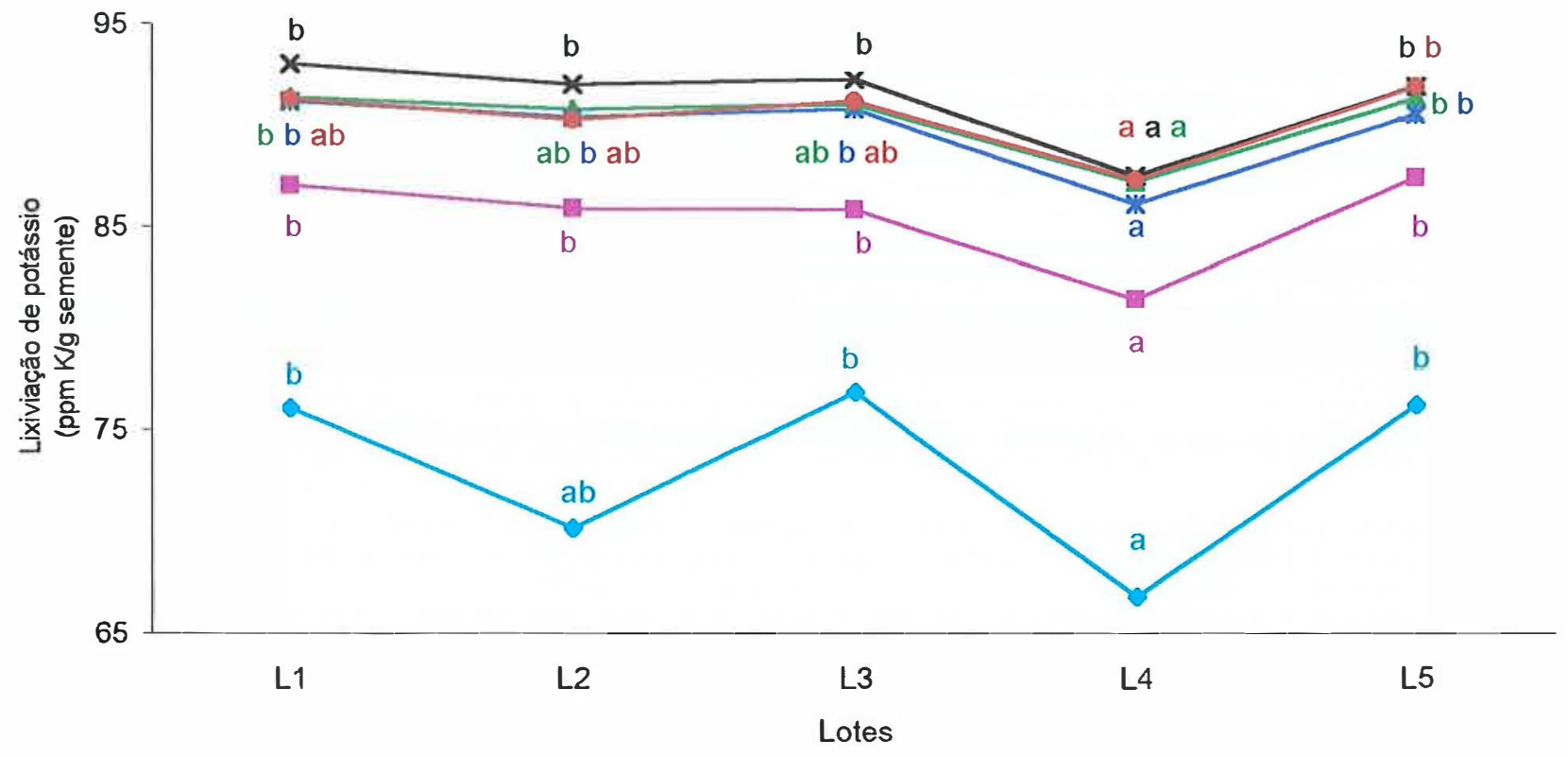

$\multimap 30$ minutos $\longrightarrow-60$ minutos $\multimap-60$ minutos $\rightarrow-120$ minutos $\rightarrow-150$ minutos $\multimap 180$ minutos

Figura 59. Híbrido Traktor: comportamento dos cinco lotes de sementes, quanto à lixiviação de potássio, no tratamento 100 sementes $/ 75 \mathrm{ml} / 25^{\circ} \mathrm{C}$ (época 2).

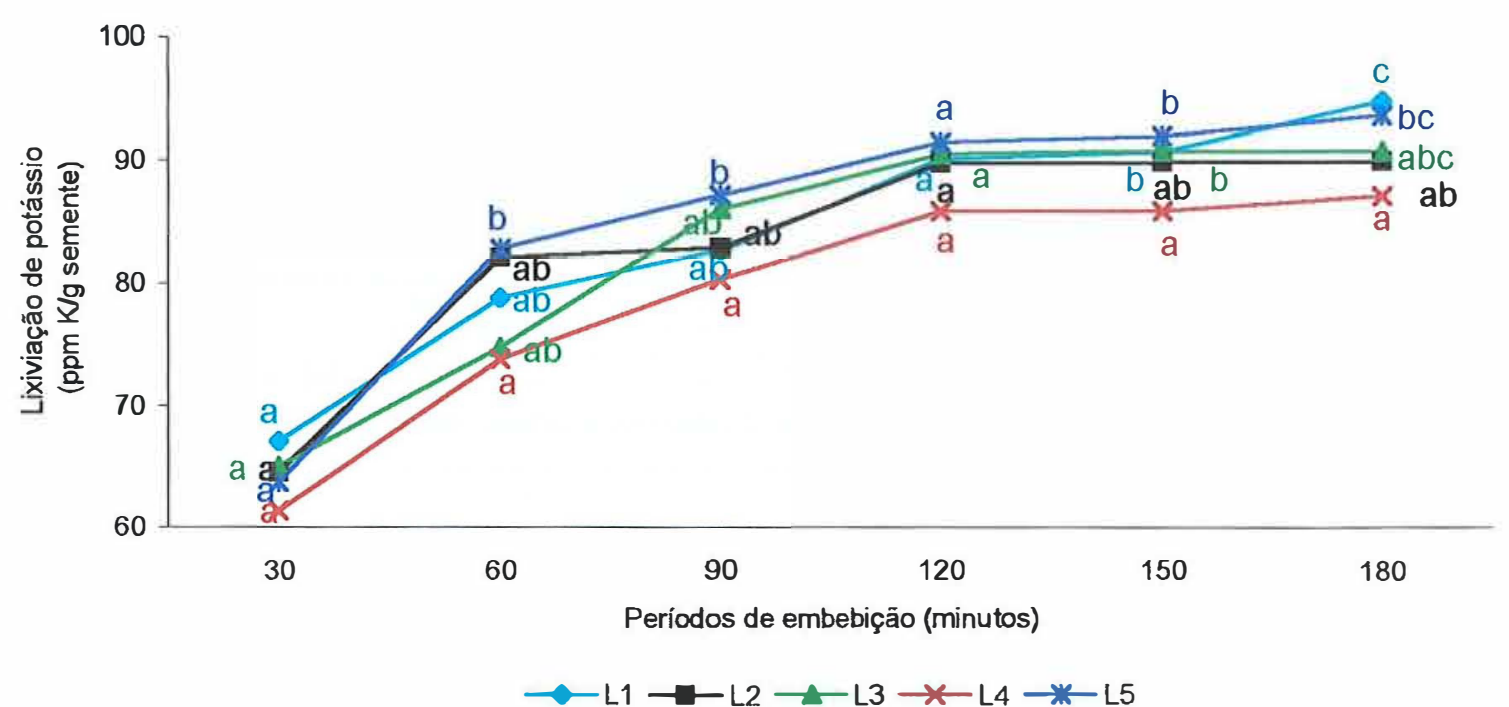


Figura 60. Híbrido Traktor: comportamento dos cinco lotes de sementes, quanto à lixiviação de potássio, no tratamento 100 sementes $/ 50 \mathrm{ml} / 25^{\circ} \mathrm{C}$ (época 2).

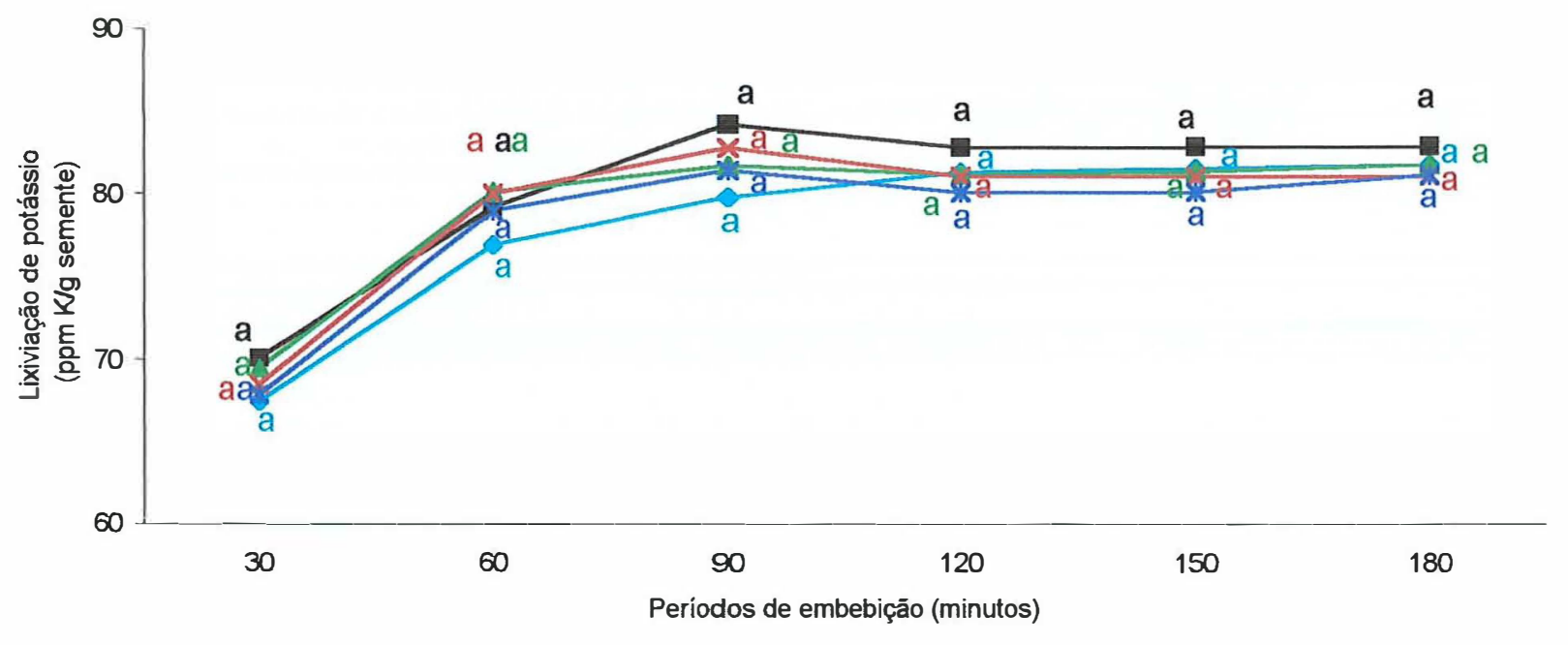

$\multimap \mathrm{L} 1 \rightarrow-\mathrm{L} 2 \rightarrow \mathrm{L} 3 \rightarrow \mathrm{L} 4 \rightarrow \mathrm{L} 5$

Figura 61. Híbrido Traktor: comportamento dos cinco lotes de sementes, quanto à lixiviação de potássio, no tratamento 50 sementes $/ 75 \mathrm{ml} / 25^{\circ} \mathrm{C}$ (época 2).

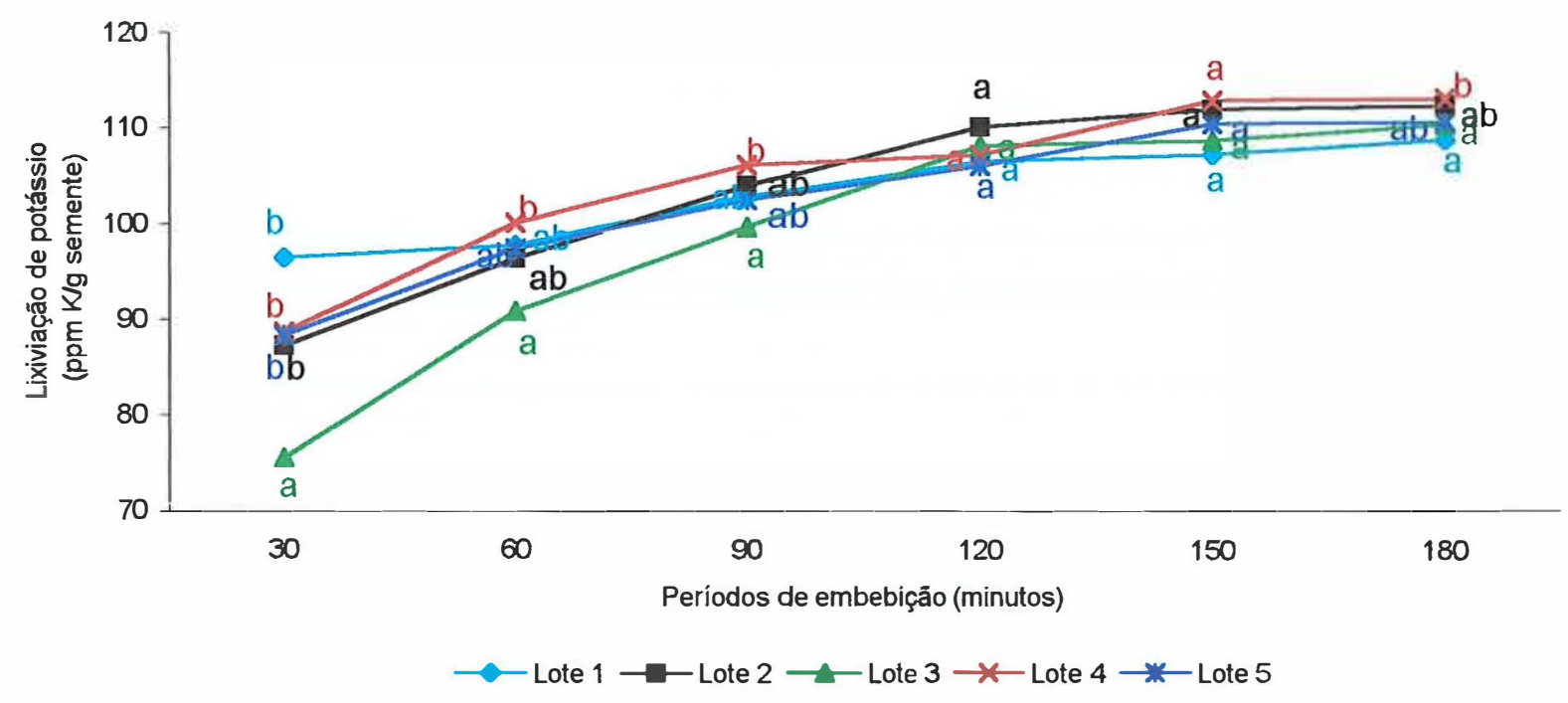


Figura 62. Híbrido Traktor: comportamento dos cinco lotes de sementes, quanto à lixiviação de potássio, no tratamento 50 sementes $/ 50 \mathrm{ml} / 25^{\circ} \mathrm{C}$ (época 2).

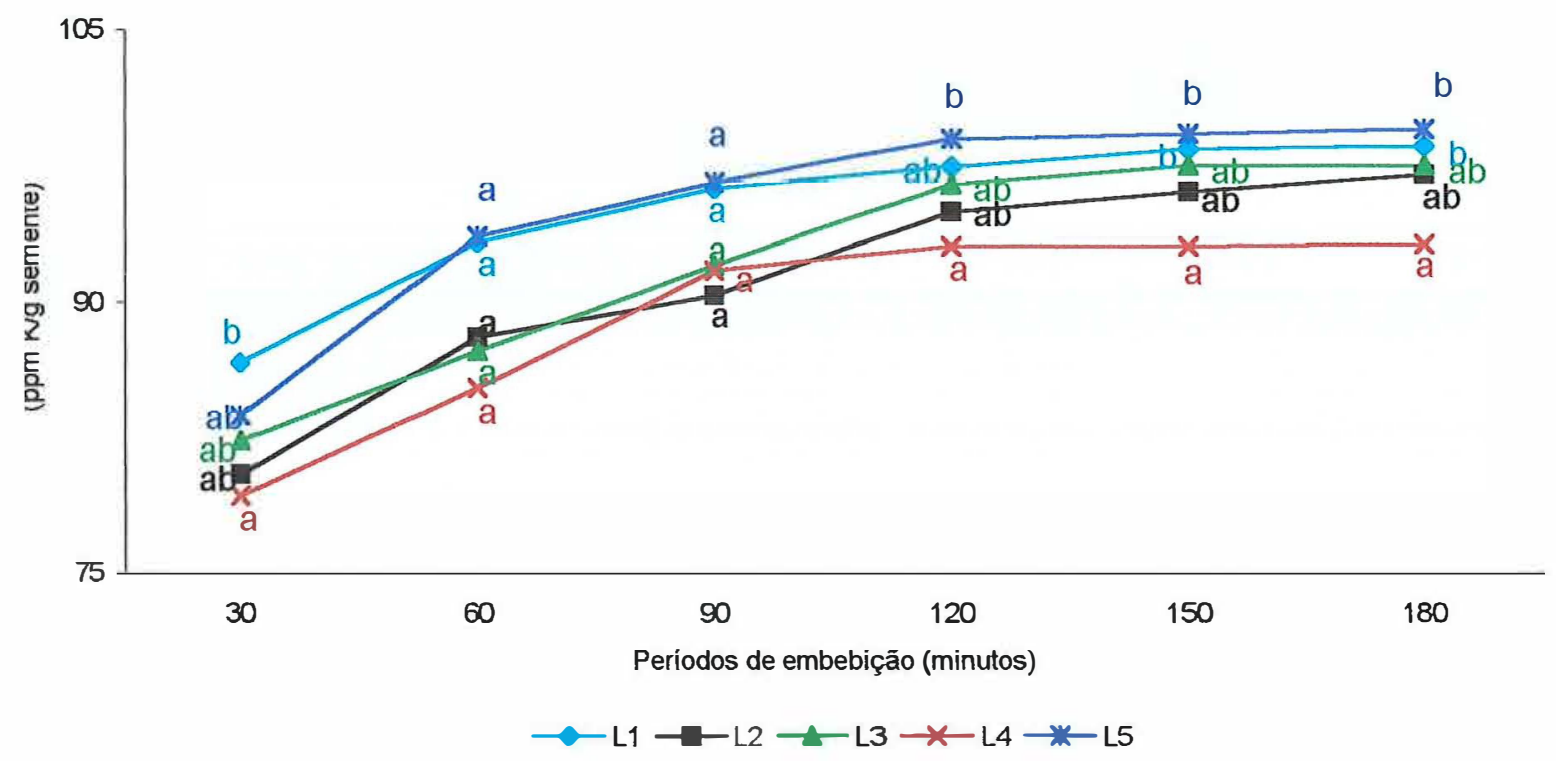

Figura 63. Híbrido Traktor: comportamento dos cinco lotes de sementes, quanto à lixiviação de potássio, no tratamento 50 sementes $/ 25 \mathrm{ml} / 25^{\circ} \mathrm{C}$ (época 2).

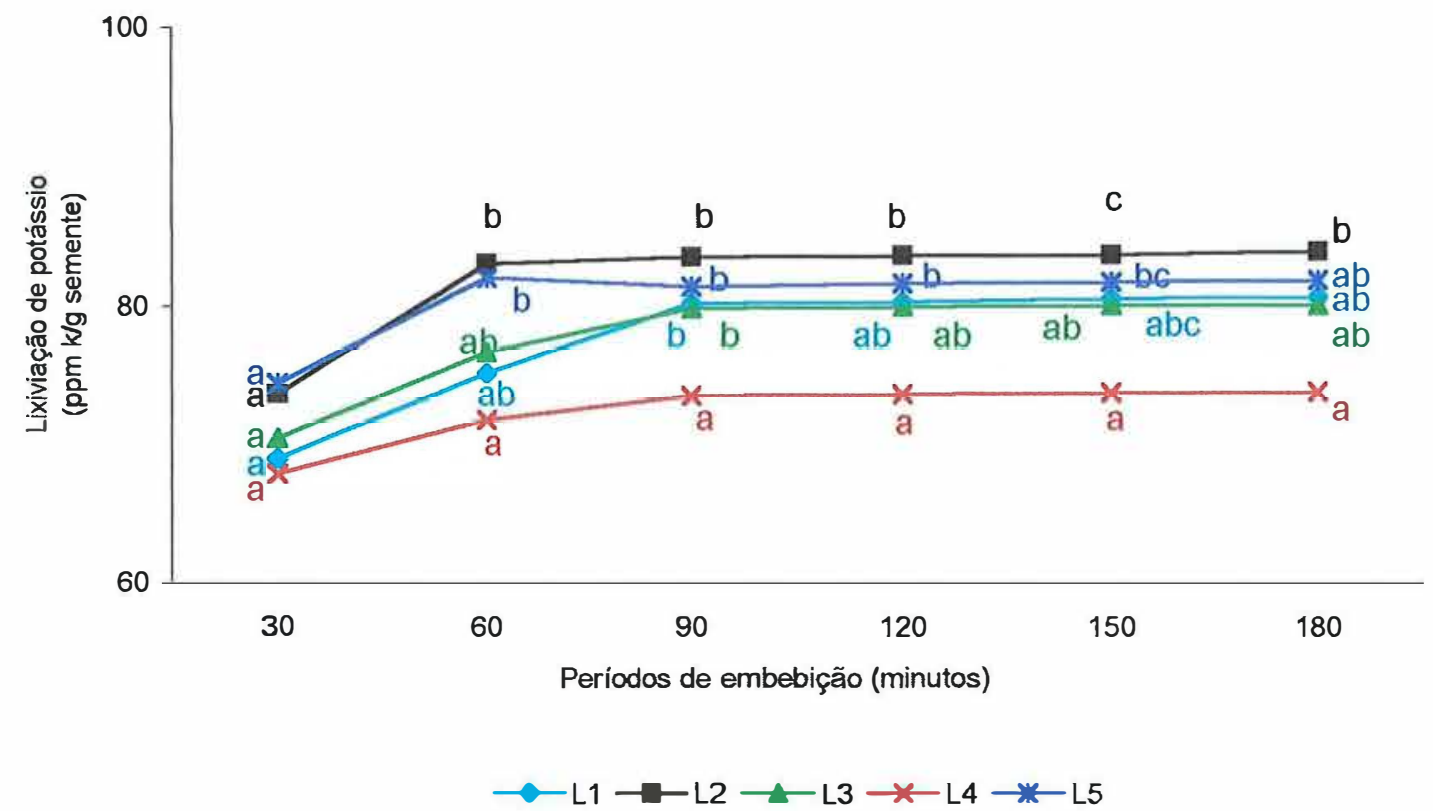


Figura 64. Híbrido Traktor: comportamento dos cinco lotes de sementes, quanto à lixiviação de potássio, no tratamento 25 sementes $/ 50 \mathrm{ml} / 25^{\circ} \mathrm{C}$ (época 2).

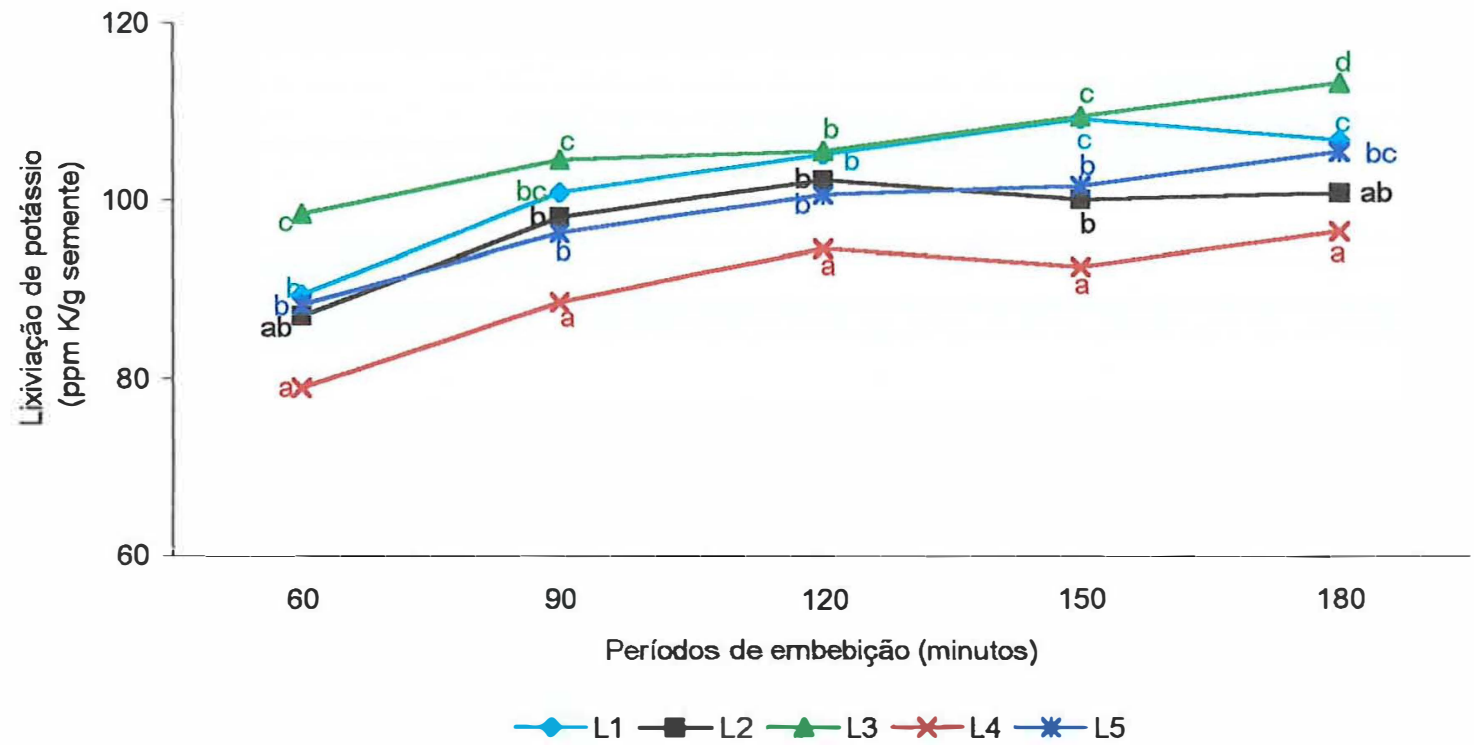

Figura 65. Híbrido Traktor: comportamento dos cinco lotes de sementes, quanto à lixiviação de potássio, no tratamento 25 sementes $/ 25 \mathrm{ml} / 25^{\circ} \mathrm{C}$ (época 2).

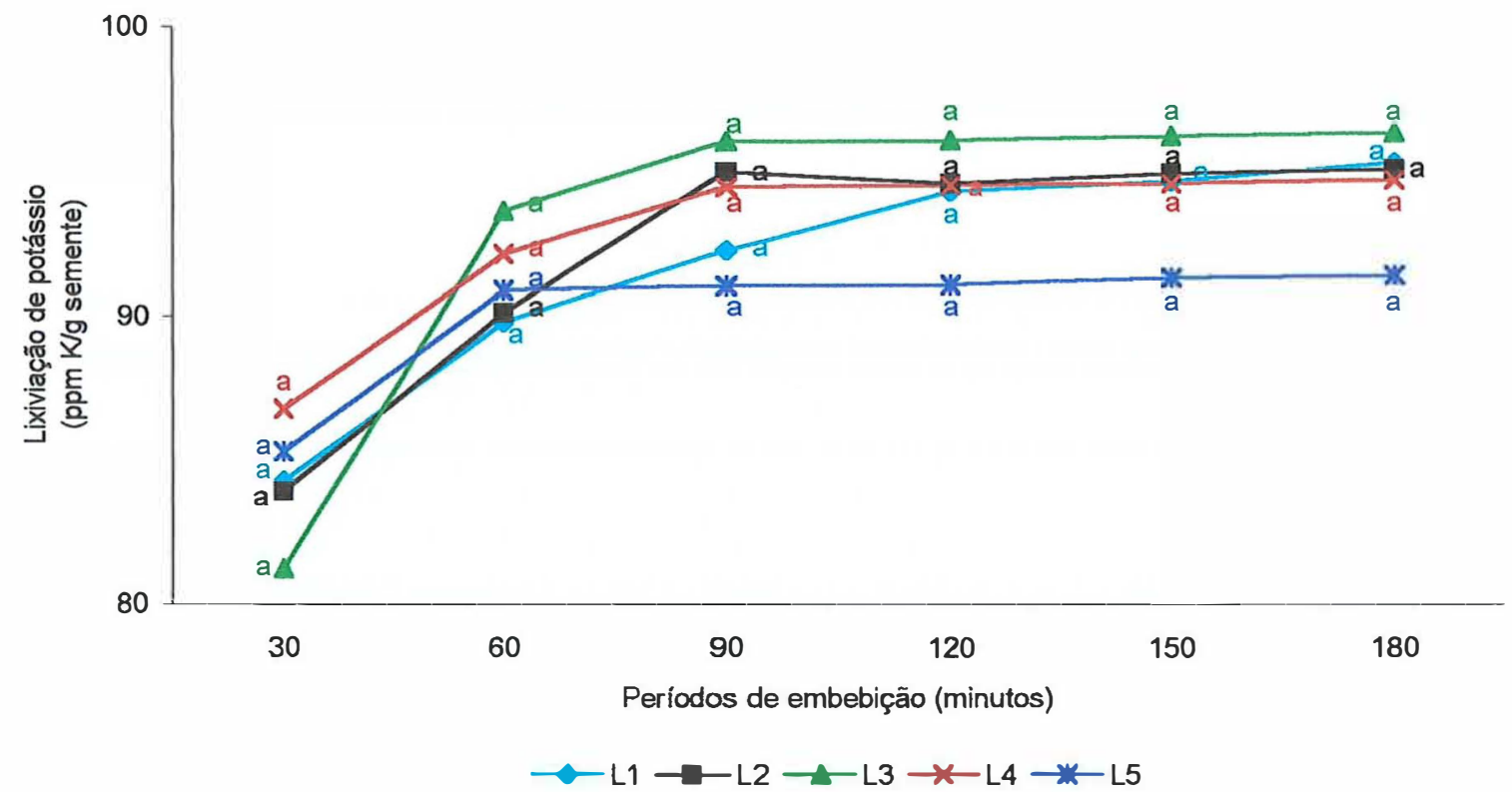


Observou-se, também, que houve inversão na classificação dos lotes nos tratamentos de 50 sementes/75 $\mathrm{ml}$ com 30, 60, 90 e 180 minutos de embebição, na época 2 (Figura 61); nesses casos, o lote 3 foi classificado como superior e o lote 4 ocupou posição inferior, de forma inversa às classificações dos testes de vigor e da maioria dos tratamentos do teste de lixiviação de potássio.

As classificações dos lotes 1, 2 e 5 variaram de acordo com a metodologia empregada. Entretanto, houve tendência em identificar o lote 5 como de qualidade inferior, pela maioria dos tratamentos; os lotes 1 e 2 variaram entre superior, intermediário e inferior, portanto, observa-se mais uma vez a inconsistência dos testes na identificação lotes com diferenças pouco acentuadas de vigor.

A leitura da lixiviação de potássio das sementes dos tratamentos de 25 sementes $/ 75 \mathrm{ml}$, em todos os períodos de embebição, nas duas épocas e de 25 sementes $/ 50 \mathrm{ml}$ com 30 minutos de embebição, na época1, não foram feitas, porque a quantidade de potássio lixiviado pelas sementes de milho não foi suficiente. Nesse caso, não houve necessidade de diluição da amostra de embebição para nenhum tratamento.

Os resultados obtidos na época 1 (Figura 58) não se repetiram, de maneira semelhante, na época 2 (Figuras 59 a 65), apesar de apresentarem as mesmas tendências. Os coeficientes de variação variaram entre $3,1 \%$ e 8,3\%.

Verifica-se que, como no híbrido AG 6690, os lotes não foram separados em niveis acentuadamente distintos de vigor; apesar disso, alguns tratamentos, que podem ser observados nas Figuras 58, 59, 61, 62, 63 e 64, detectaram diferenças de qualidade entre os lotes. 


\subsubsection{Testes de lixiviação de potássio realizados a $30^{\circ} \mathrm{C}$}

Nos testes realizados a $30^{\circ} \mathrm{C}$, os tratamentos também não influenciaram na classificação dos lotes na época 1 , em todos os períodos de embebição. $A$ interação tratamentos $x$ lotes somente foi significativa na época 2.

Dessa forma, a Figura 66 representa o valor médio da lixiviação dos cinco lotes em todos os tratamentos e períodos de embebição e as Figuras 67 a 73 mostram os resultados da época 2 , onde os tratamentos interferiram na identificação dos lotes, dentro de cada período de embebição.

As classificações dos lotes a $30^{\circ} \mathrm{C}$ foram semelhantes às de $25^{\circ} \mathrm{C}$. Portanto, houve consistência da identificação do lote 4 como de melhor potencial fisiológico e a tendência em apontar o lote 3 como inferior, pelos tratamentos que detectaram diferenças de qualidade entre os lotes; nos testes de vigor ocorreu o inverso: houve consistência na identificação do lote 3 como inferior e tendência de identificação do lote 4 como superior.

Os lotes 1, 2 e 5, classificados como intermediários pelos testes de vigor, seguiram a mesma tendência nos testes de lixiviação de potássio; o lote 5, em geral, foi identificado como inferior, em relação ao potencial fisiológico; os lotes 1 e 2 variaram entre superiores, intermediários e inferiores.

Da mesma forma que a $25^{\circ} \mathrm{C}$ e que os testes de frio e emergência de plântulas em campo, determinados tratamentos não foram capazes de distinguir niveis de vigor diferentes entre os lotes, em todos os períodos de embebição (Figuras 68 e 71).

Os tratamentos de 100 sementes $/ 75 \mathrm{ml}$ com 30,60 e 120 minutos de embebição (Figuras 67) classificou os lotes da mesma maneira que o teste de condutividade elétrica (Figura 4).

Apesar de seguirem a mesma tendência, não houve repetibilidade entre os resultados das épocas 1 e 2.

Os coeficientes de variação foram mais altos a $30^{\circ} \mathrm{C}(3,8 \%$ a $17,0 \%)$ do que a $25^{\circ} \mathrm{C}$, mas ainda assim garantiram a confiabilidade do teste. 
Figura 66. Híbrido Traktor: avaliação do potencial fisiológico de cinco lotes de sementes, quanto a lixiviação de potássio, na época 1.

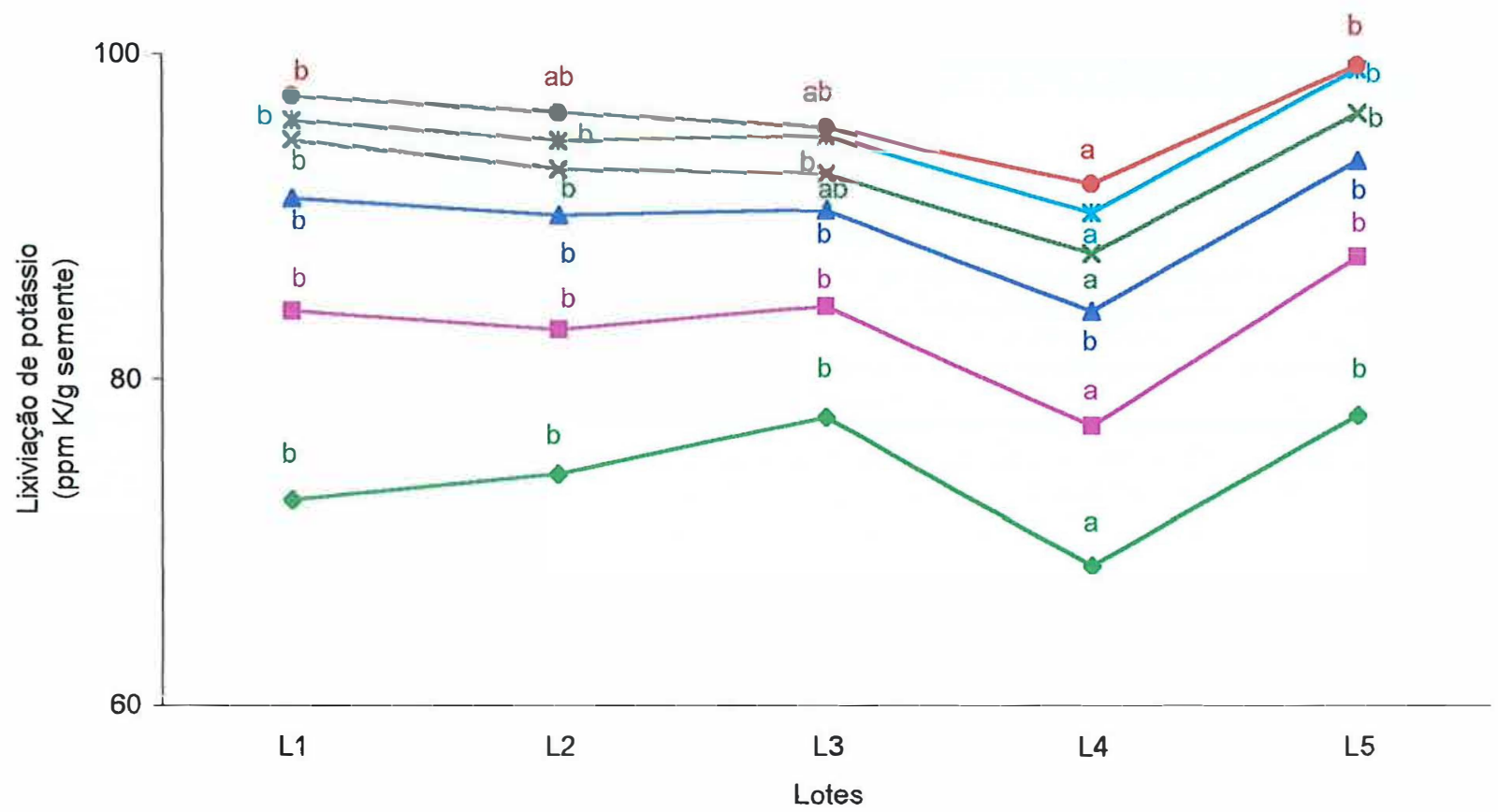

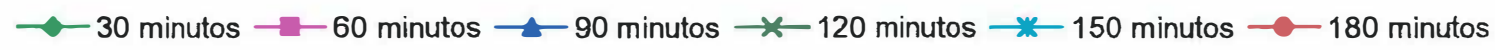


Figura 67. Hibrido Traktor: comportamento dos cinco lotes de sementes, quanto à lixiviação de potássio, no tratamento 100 sementes $/ 75 \mathrm{ml} / 30^{\circ} \mathrm{C}$ (época 2).

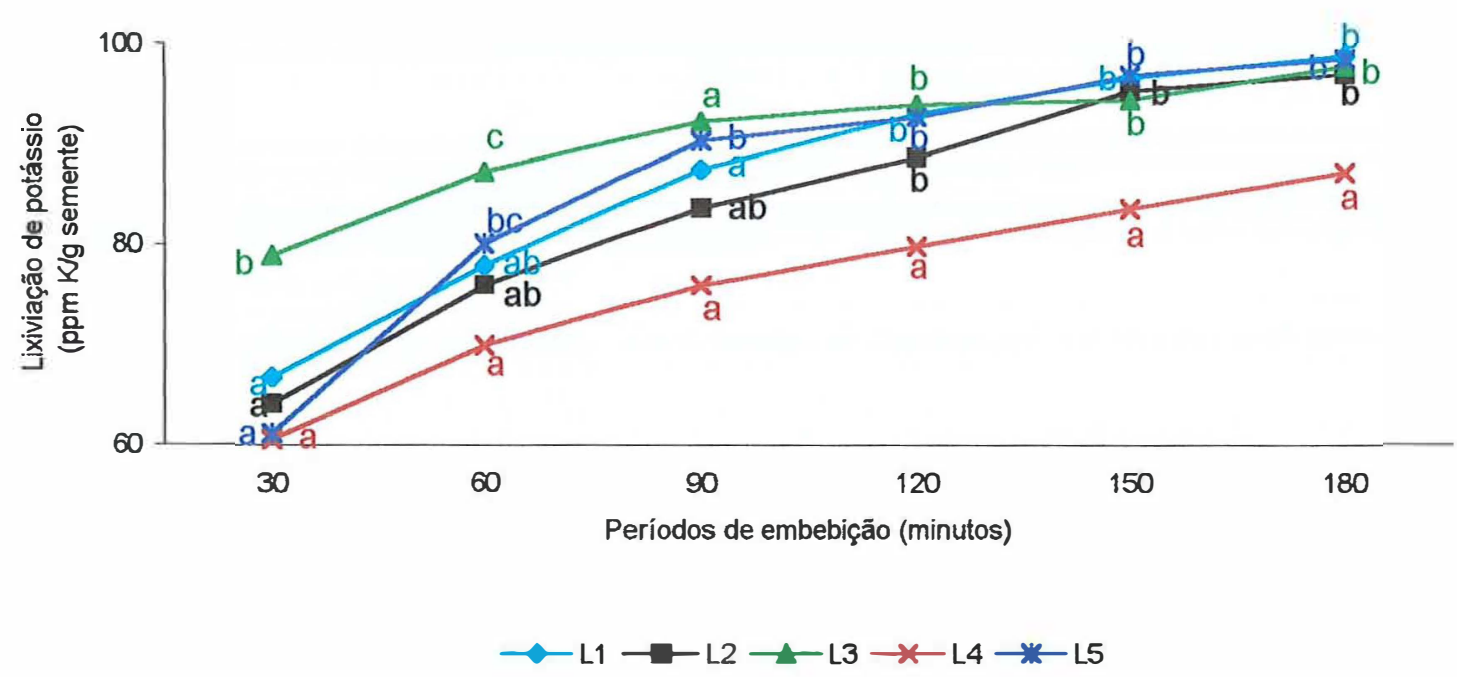

Figura 68. Híbrido Traktor: comportamento dos cinco lotes de sementes, quanto à lixiviação de potássio, no tratamento 100 sementes $/ 50 \mathrm{ml} / 30^{\circ} \mathrm{C}$ (época 2).

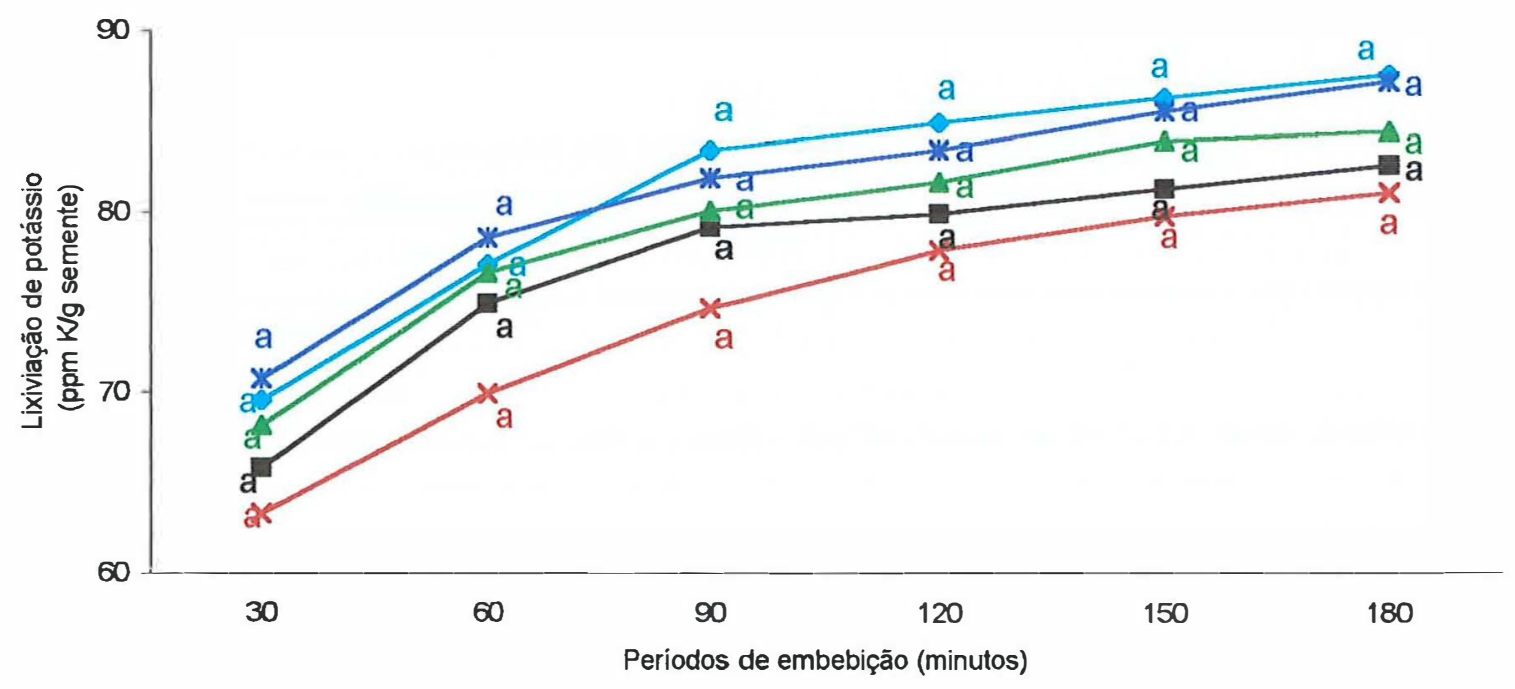


Figura 69. Híbrido Traktor: comportamento dos cinco lotes de sementes, quanto à lixiviação de potássio, no tratamento 50 sementes $/ 75 \mathrm{ml} / 30^{\circ} \mathrm{C}$ (época 2).

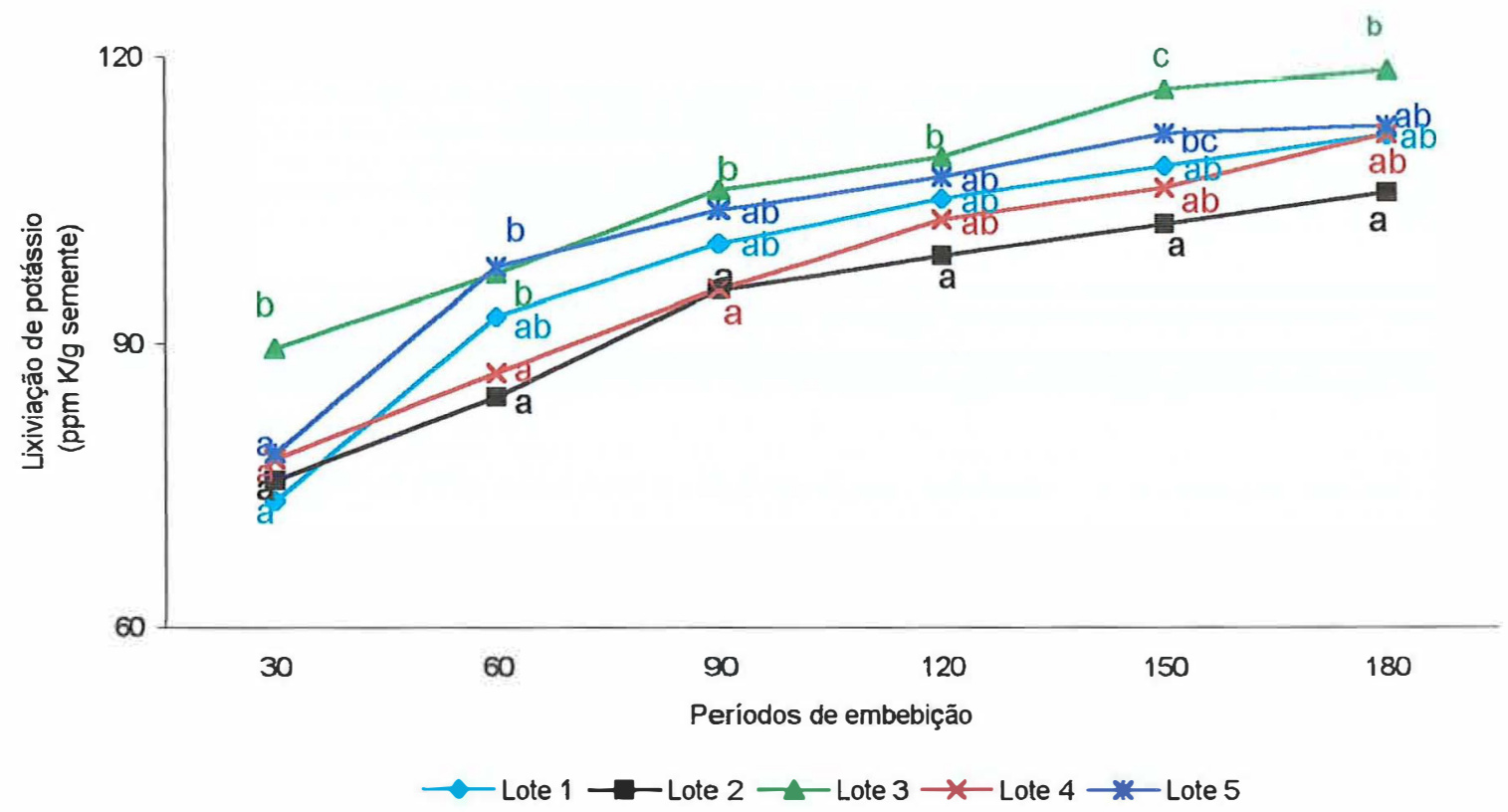

Figura 70. Híbrido Traktor: comportamento dos cinco lotes de sementes, quanto à lixiviação de potássio, no tratamento 50 sementes $/ 50 \mathrm{ml} / 30^{\circ} \mathrm{C}$ (época 2).

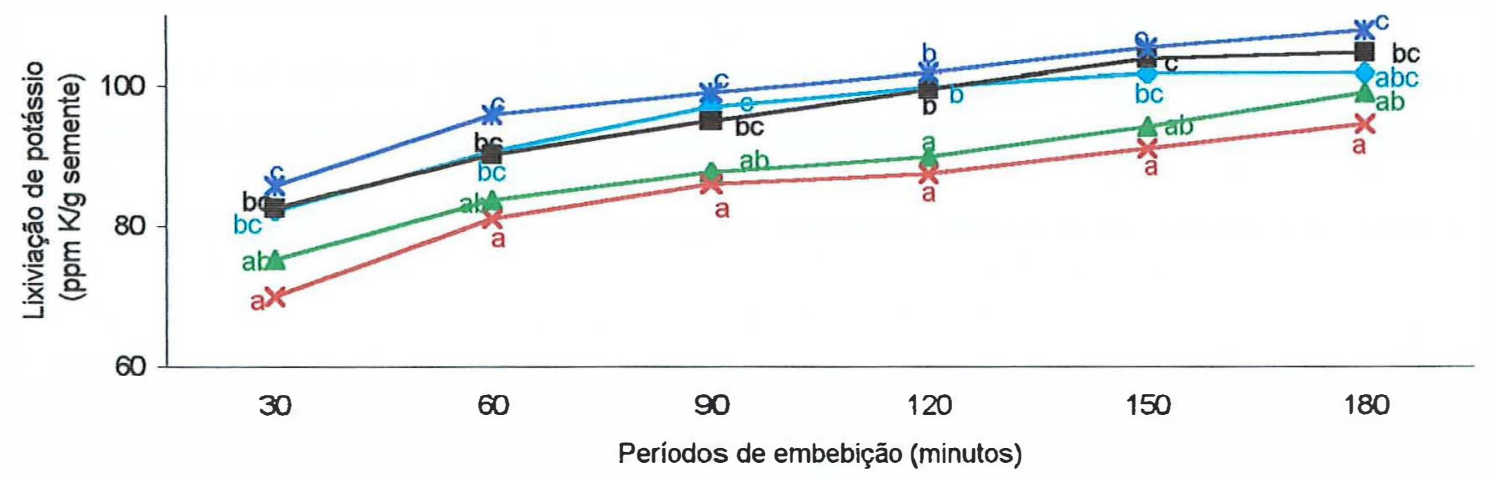


Figura 71. Híbrido Traktor: comportamento dos cinco lotes de sementes, quanto à lixiviação de potássio, no tratamento 50 sementes $/ 25 \mathrm{ml} / 30^{\circ} \mathrm{C}$ (época 2 ).

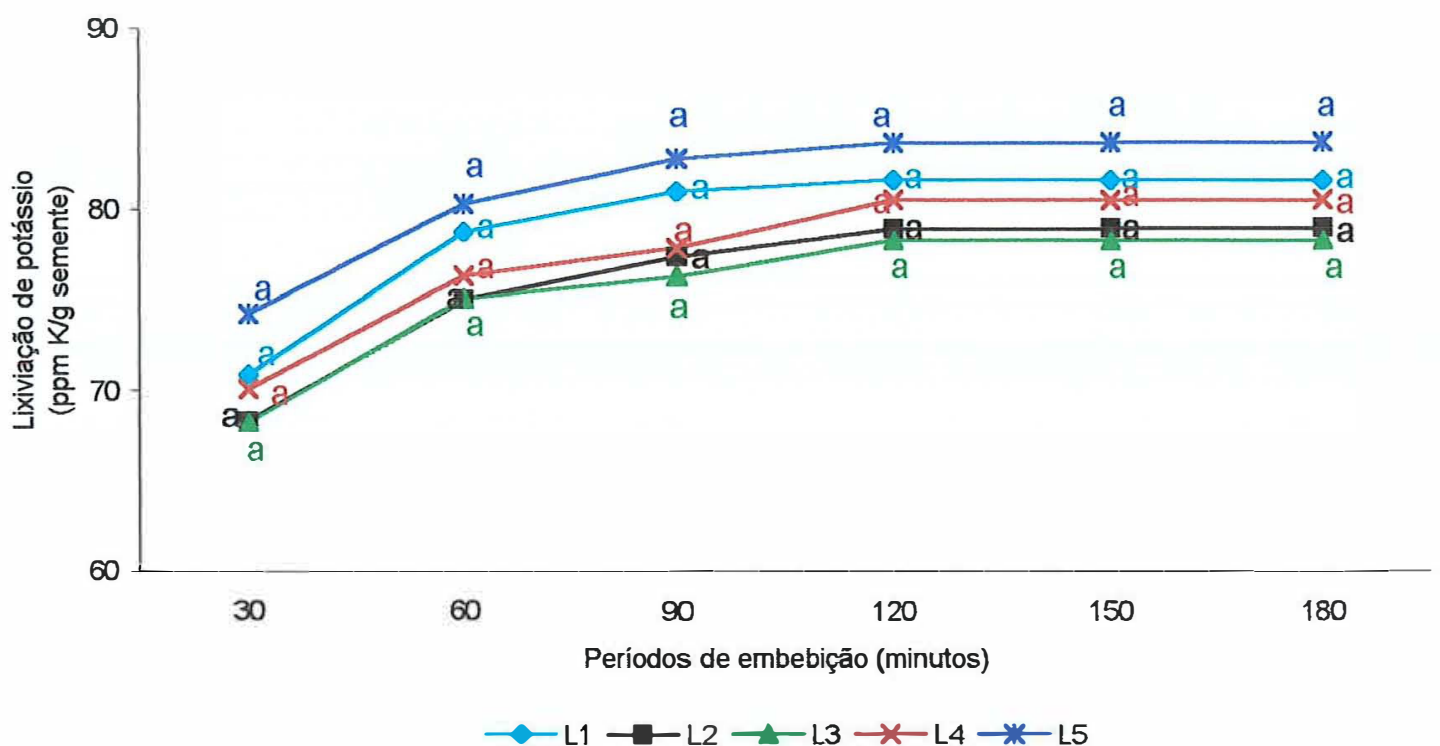

Figura 72. Híbrido Traktor: comportamento dos cinco lotes de sementes, quanto à lixiviação de potássio, no tratamento 25 sementes $/ 50 \mathrm{ml} / 30^{\circ} \mathrm{C}$ (época 2).

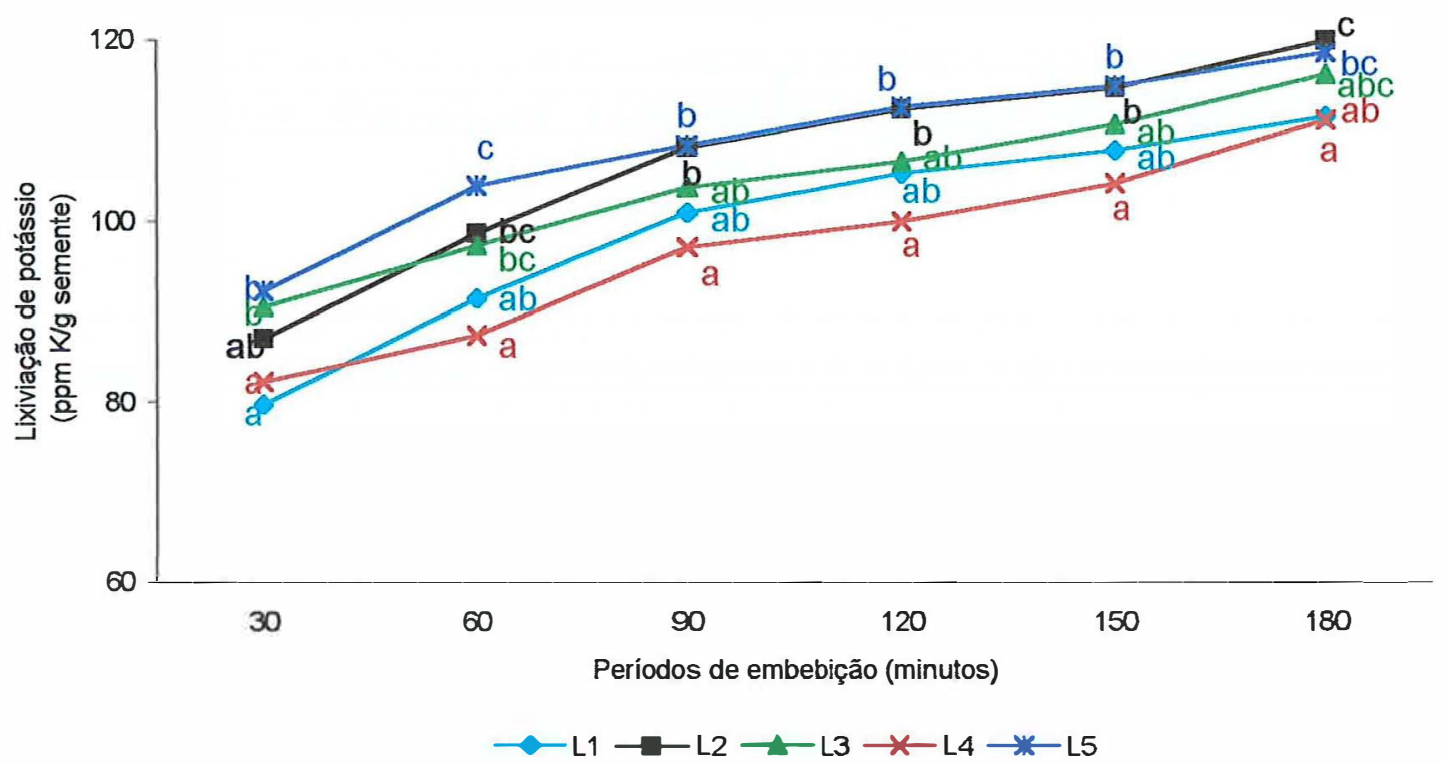


Figura 73. Híbrido Traktor: comportamento dos cinco lotes de sementes, quanto à lixiviação de potássio, no tratamento 25 sementes $/ 25 \mathrm{ml} / 30^{\circ} \mathrm{C}$ (época 2).

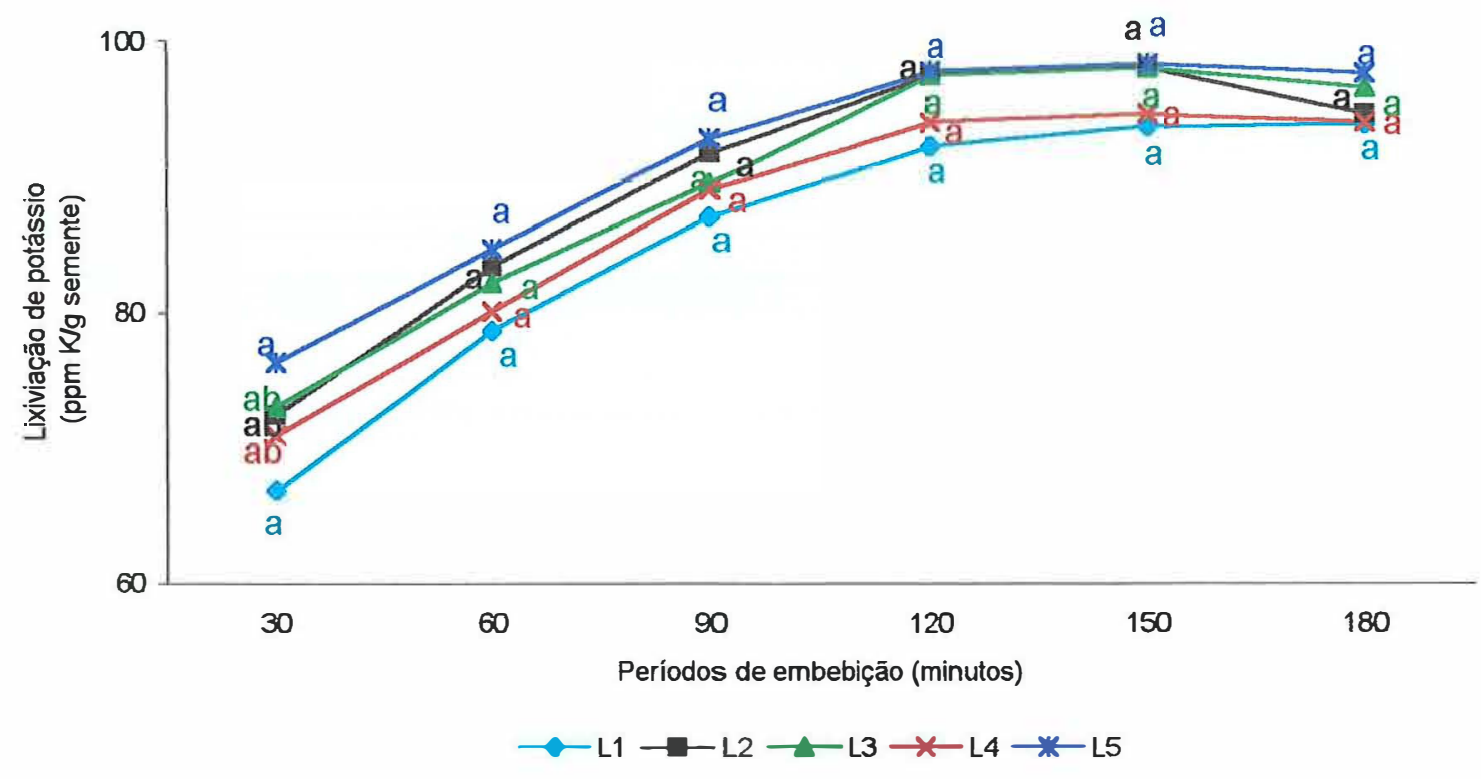

\subsubsection{Considerações gerais}

A análise dos resultados permitiu verificar que a determinação do íon potássio exsudado pelas sementes, em função da reorganização das membranas celulares por ocasião da embebição, constitui alternativa interessante na deteç̧ão de níveis de potencial fisiológico entre lotes de sementes de milho.

As sementes atingem o máximo de qualidade e organização de suas membranas celulares por ocasião da maturidade fisiológica. Como, hipoteticamente, a desorganização das membranas é o primeiro evento do processo deteriorativo após a maturidade fisiológica, os testes que avaliam esse parâmetro seriam mais sensíveis para estimar o vigor (Delouche e Baskin, 1973; Marcos Filho, 1999a). Há um decréscimo na permeabilidade das membranas à medida que a semente deteriora (McDonald, 1999), com reflexos 
sobre sua capacidade de regular o fluxo de água e de solutos, tanto de dentro para fora, como no sentido oposto, considerando-se tanto células, como suas organelas (Carvalho, 1994).

Wood (1990), associou a perda de potássio aos danos à membrana, em um trabalho para determinação de perdas de minerais em plântulas de soja, girassol e sorgo.

Powell et al. (1986) mostraram evidências de danos durante a embebição de sementes de feijão, com a morte de tecidos e aumento na lixiviação de solutos. Lin (1988), trabalhando com sementes de milho, concluiu que o teor de água das sementes aumentou, durante o armazenamento ocasionando a deterioração da membrana plasmática e conseqüente queda no vigor e na germinação, avaliados pelo aumento da lixiviação de eletrólitos.

Várias pesquisas indicaram que a quantidade de potássio lixiviado pelas sementes durante a embebição pode ser um referencial da perda do potencial fisiológico. Entre estas, pode-se citar as de Halloin (1975), McKersie e Stinson (1980), Woodstock et al. (1985), Weges e Karssen (1990), Dias et al. (1996) e Custódio e Marcos Filho (1997).

Dias et al. (1996) verificaram que a quantidade de potássio lixiviado em sementes de soja, permitiu a identificação de lotes com diferentes níveis de vigor e potencial de emergência de plântulas em campo, revelando a sua importância para a dinamização dos programas de controle de qualidade destas sementes.

De maneira geral, as tendências de classificação dos lotes dos híbridos Avant, AG 6690 e Traktor obtidas nos tratamentos para o teste de lixiviação de potássio foram as mesmas fornecidas pelos testes de vigor utilizados nas avaliações preliminares. No entanto, observa-se que os tratamentos se comportaram diferentemente entre os híbridos; o melhor desempenho ocorreu com o híbrido Avant, provavelmente devido a maior diferença de qualidade entre os lotes ou a maior eficiência do teste para esse híbrido. 
Observou-se, também, que os tratamentos foram mais eficientes na detecção do vigor dos lotes de qualidade extremas, ficando prejudicada a avaliação dos lotes de qualidade intermediária, como já observado por Woodstock, 1973; Tekrony e Egly, 1977; Marcos Filho, 1998 e Carvalho e Nakagawa, 2000.

O fato do teste de lixiviação de potássio não ter determinado a qualidade dos lotes dos três híbridos, com a mesma eficiência, sugere que pode ser necessária a sua padronização específica para cada material. Assim, a pesquisa deveria desenvolver melhor o teste de lixiviação de potássio para efetuar recomendações consistentes às empresas de sementes de milho.

A definição de uma metodologia adequada deve considerar alguns pontos, como, por exemplo: o período de embebição deve ser tal que permita a leitura do potássio exsudado sem a necessidade de diluição pois, como pode ser verificado em alguns casos, a quantidade de potássio lixiviada foi insuficiente e, em outros, excessivas. Diante da impossibilidade de identificar a qualidade do lote antes da avaliação e pensando na rotina de uma empresa, acredita-se que para leituras com aparelhos calibrados com padrão de 50 ppm de potássio o período de 90 a $25^{\circ} \mathrm{C}$ (coeficientes de variação mais baixos)minutos seria o mais indicado.

Uma outra opção seria a utilização de um padrão com menor concentração, nos casos de leitura insuficiente, ou de maior concentração, nos casos de diluição. Entretanto, a cada mudança de padrão o aparelho teria que ser novamente calibrado, o que demandaria tempo e prejudicaria a agilidade do teste. Além disso, à medida que se aumenta a concentração de potássio da solução de calibração aumenta também a imprecisão dos dados. Dessa forma, o padrão de 50 ppm de potássio, demonstra ser a melhor alternativa para os híbridos estudados.

Outro fator importante é a combinação do número de sementes e o volume de água, que deve permitir uma avaliação adequada do vigor dos lotes. 
Existem estudos que comparam a eficiência do teste de lixiviação de potássio em relação ao teste de condutividade elétrica, por terem o mesmo princípio, com a diferença de que o primeiro é mais rápido por considerar a lixiviação apenas do íon potássio enquanto que o segundo quantifica a liberação de um conjunto de íons.

No presente trabalho, os resultados das classificações dos lotes fornecidas pelo teste de lixiviação de potássio foram, em geral, semelhantes às fornecidas pelo teste de condutividade elétrica, concordando com Simon e Raja-Harum (1972) e Halloin (1975) que afirmaram que a avaliação de potássio lixiviado proporciona praticamente as mesmas informações fornecidas pelo teste de condutividade elétrica, uma vez que se baseiam em princípio semelhante. Panobianco (2000) trabalhando com sementes de tomate, verificou maior eficiência na determinação de apenas um íon em relação a um conjunto de íons, provavelmente devido a interferência destes na avaliação.

Em contrapartida, Marcos Filho et al. (1984) e Barros e Marcos Filho (1988) não encontraram semelhança entre os resultados de condutividade elétrica e lixiviação de potássio, em sementes de soja.

Assim, comprovou-se da tendência da quantificação de apenas um íon, no caso o potássio, durante o processo de reorganização das membranas, permitindo respostas mais rápidas, em relação ao vigor das sementes. A classificação dos lotes no teste de lixiviação de potássio foi possível com 30 minutos de embebição, enquanto que as respostas do teste de condutividade são obtidas em 24 horas, se conduzido da maneira recomendada tradicionalmente (AOSA, 1983). 


\subsection{Relações entre a lixiviação de p otássio e as alterações de temperatura, períodos de embebição, número de sementes e volume de embebição}

\subsubsection{Temperatura}

Leopold (1980), Murphy e Noland (1982) ressaltaram que o efeito da temperatura sobre a embebição e lixiviação pode estar relacionado com alterações na viscosidade da água, interferindo tanto na quantidade como na velocidade de liberação de exsudatos.

Em temperaturas baixas, o processo de reorganização de membranas é mais lento e aumenta o período de perda de lixiviados pelas sementes; em altas temperaturas, há dano térmico às membranas, causando aumento na lixiviação (Givelberg, et al., 1984).

Custódio e Marcos Filho (1997), trabalhando com sementes de soja, verificaram que, em geral, os valores de potássio lixiviado foram maiores quando a embebição foi realizada a $30^{\circ} \mathrm{C}$, em relação a $25^{\circ} \mathrm{C}$, indicando que o aumento da lixiviação de potássio foi proporcional ao aumento da temperatura de embebição.

No entanto, para as sementes de milho essa relação não foi observada no presente trabalho; em vários casos, verificaram-se valores maiores de lixiviação de potássio a $25^{\circ} \mathrm{C}$ do que a $30^{\circ} \mathrm{C}$ ou valores próximos, para um mesmo tratamento. As Figuras 74, 75 e 76 mostram exemplos dessa tendência, para os três híbridos Avant, AG 6690 e Traktor, respectivamente.

Assim, pode-se afirmar que, para as sementes de milho, a diferença de $5^{\circ} \mathrm{C}$ na temperatura não foi suficiente para interferir no processo de lixiviação de potássio, não havendo uma relação direta entre o aumento da temperatura e o aumento da lixiviação de potássio, como observado no trabalho de Custódio e Marcos Filho (1997). No entanto, os coeficientes de variação obtidos a $30^{\circ} \mathrm{C}$ $(8,6 \%$ a $16,1 \%)$ foram maiores do que os obtidos a $25^{\circ} \mathrm{C}(4,9 \%$ a $9,7 \%)$. Dessa 
forma, seria aconselhável optar pelo uso da temperatura de $25^{\circ} \mathrm{C}$, para a obtenção de resultados mais confiáveis.

Figura 74. Híbrido Avant: influência da temperatura na lixiviação de potássio, mantendo-se constantes o número de sementes (100), volume (75 ml) e período de embebição (60 minutos).

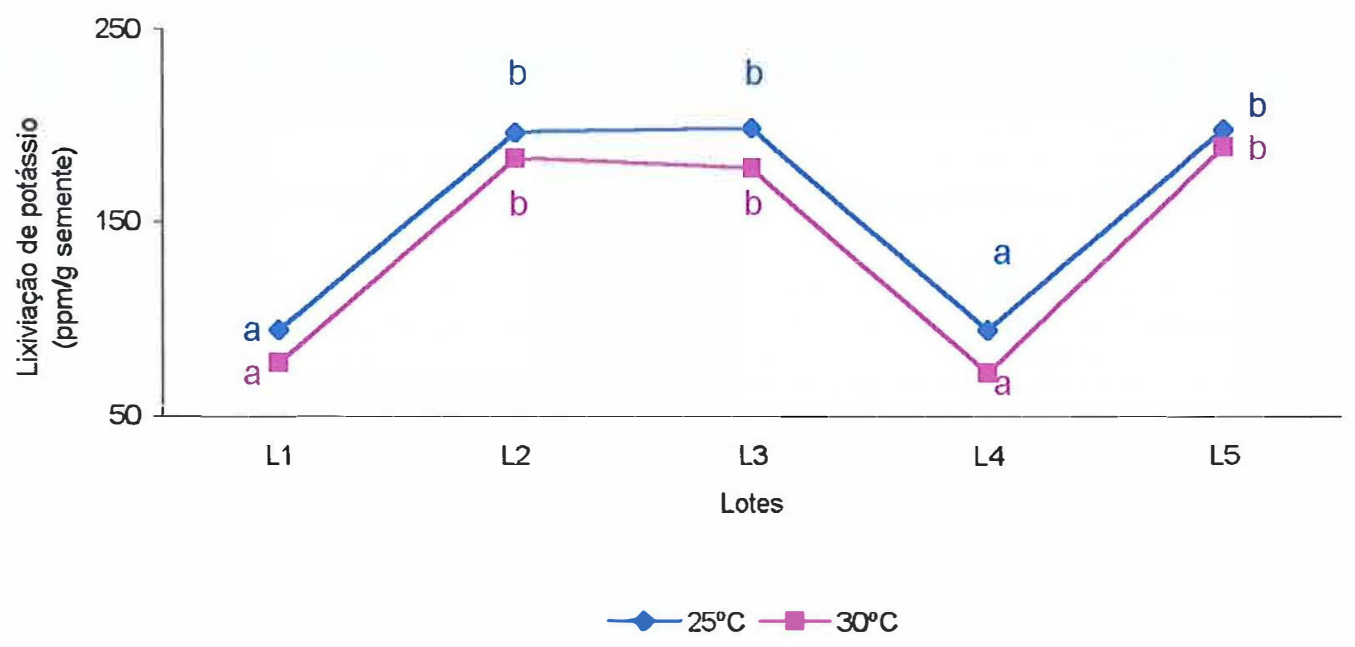

Figura 75. Híbrido AG 6690: influência da temperatura na lixiviação de potássio, mantendo-se constantes o número de sementes (100), volume $(50 \mathrm{ml})$ e período de embebição (90 minutos).

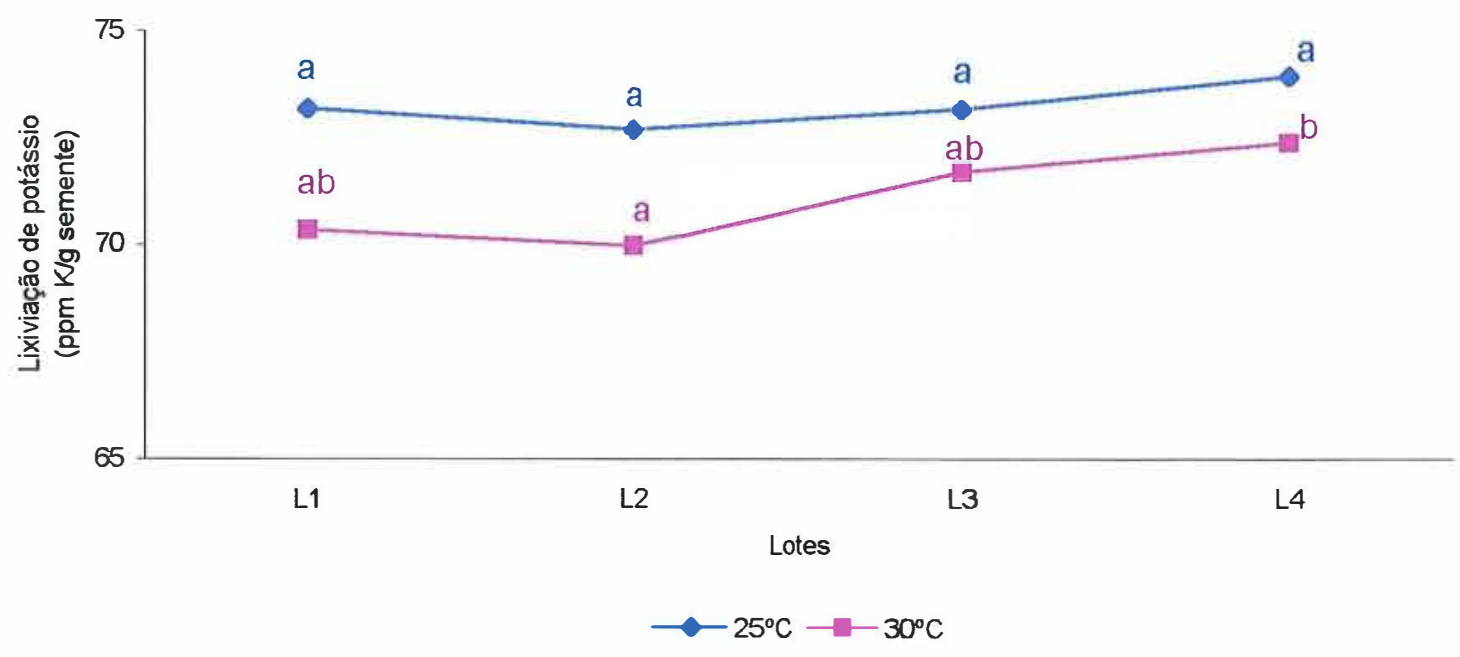


Figura 76. Híbrido Traktor: influência da temperatura na lixiviação de potássio, mantendo-se constantes o número de sementes (100), volume (50 ml) e período de embebição (90 minutos).

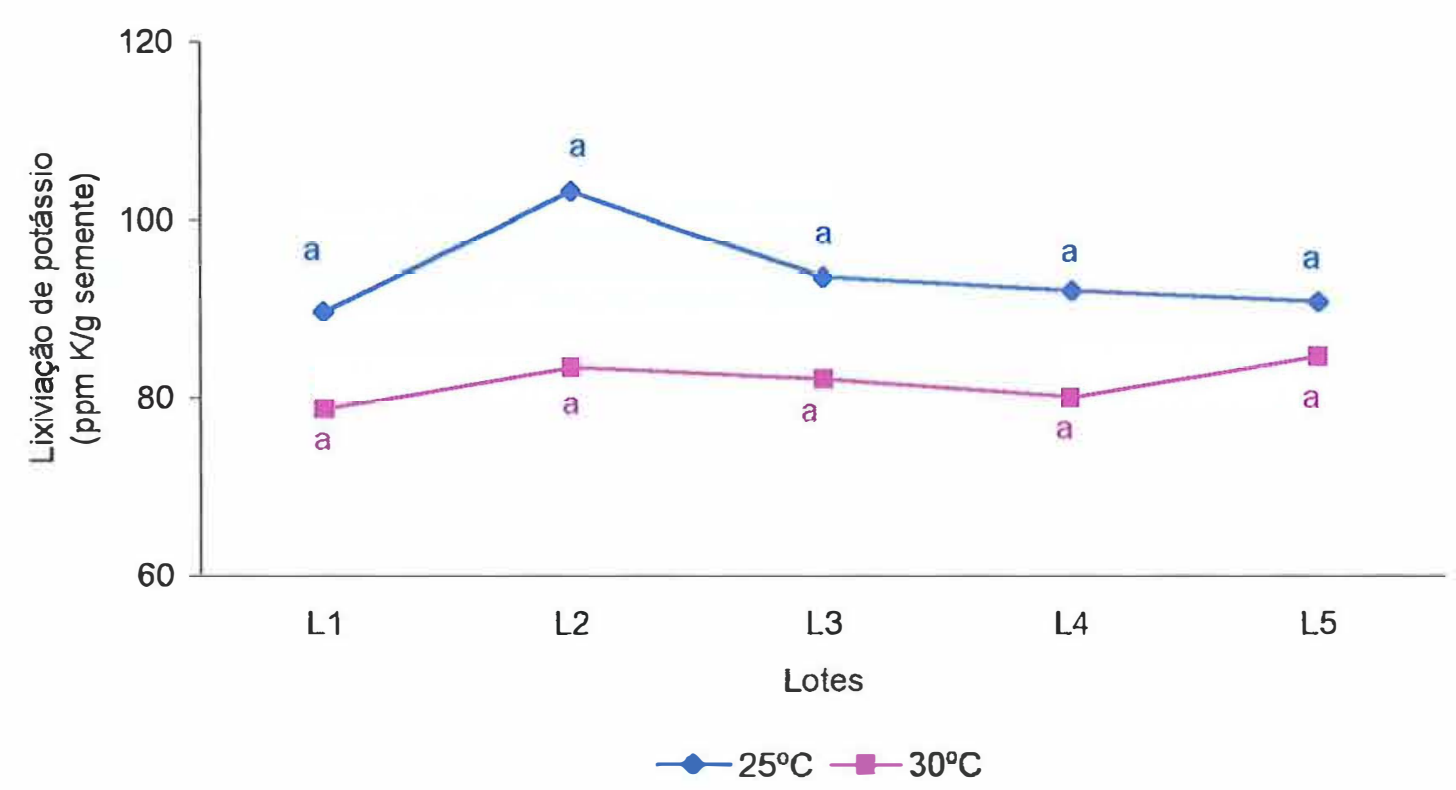

\subsubsection{Períodos de Embebição}

A análise dos resultados dos três híbridos estudados, nas temperaturas de $25^{\circ} \mathrm{C}$ e $30^{\circ} \mathrm{C}$, mostrou que, de maneira geral, as quantidades de potássio lixiviado aumentaram com o decorrer do período de embebição (Figuras 7 a 73).

Simon e Mathavan (1986), trabalhando com sementes de diferentes espécies, concluiu que um grupo de sementes, entre elas ervilha, feijão e girassol, absorvem água e lixiviam solutos por um período que se estende por várias horas. Um segundo grupo de espécies, no qual se incluem várias umbelíferas, completam ambas, absorção de água e lixiviação, em 60 minutos ou até em período menor.

Os resultados obtidos no presente trabalho indicam que as sementes de milho se enquadram no grupo em que a lixiviação se estende por mais tempo 
pois, em geral, os resultados não se estabilizaram até 180 minutos de embebição, como já observado por Carvalho et al., (1999).

\subsubsection{Número de Sementes}

Em princípio acreditava-se que com o aumento do número de sementes, mantendo-se constantes a temperatura, o volume e período de embebição os valores da lixiviação seriam mais altos, pois haveria um maior número de sementes exsudando potássio (Carvalho, et al., 1999).

Entretanto, em geral, esse fato não foi observado; o aumento do número de sementes proporcionou valores mais baixos ou semelhantes, de lixiviação de potássio. Esse fato ocorreu para os três híbridos estudados e podem ser observados nas Figuras 77, 78 e 79.

Figura 77. Híbrido Avant: influência do número de sementes mantendo-se constantes o volume de embebição $(75 \mathrm{ml})$, a temperatura $\left(30^{\circ} \mathrm{C}\right)$ e o período de embebição (90 minutos).

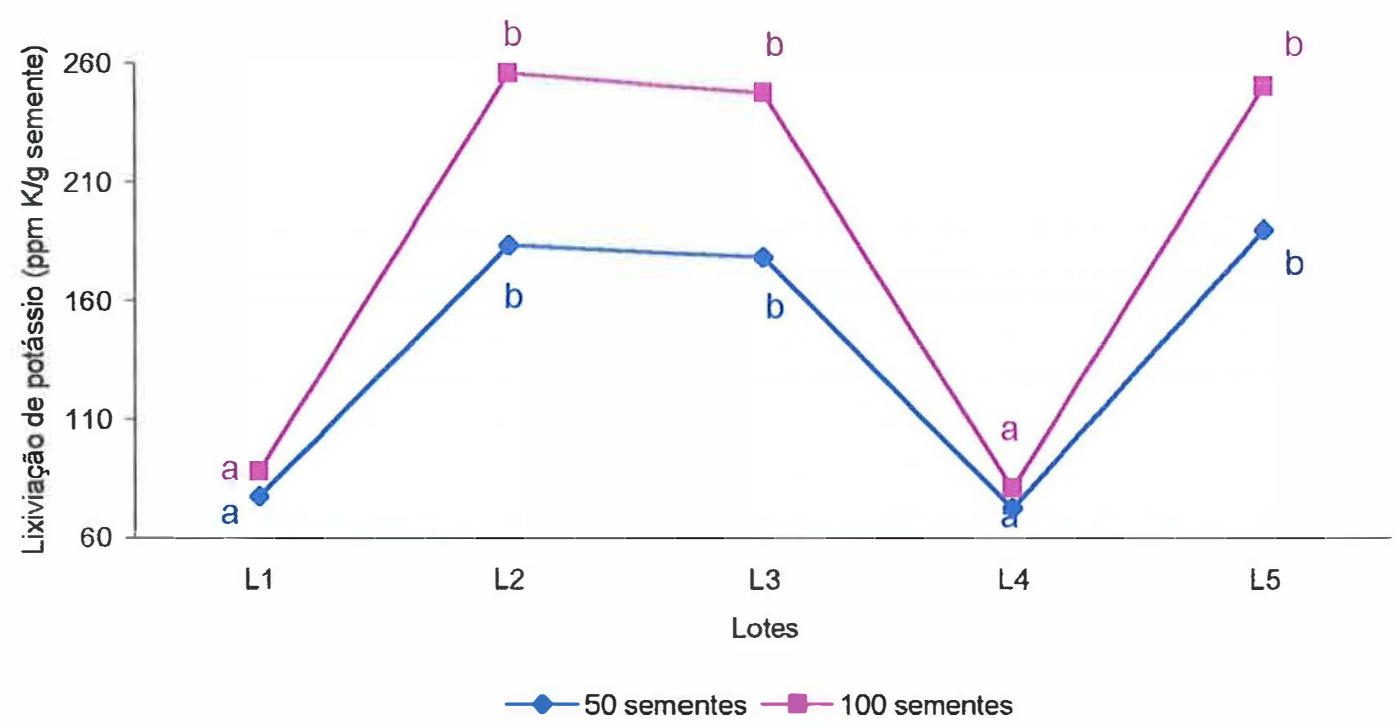


Figura 78. Híbrido AG 6690: influência do número de sementes na lixiviação de potássio, mantendo-se constantes volume $(75 \mathrm{ml})$ e período de embebição (90 minutos).

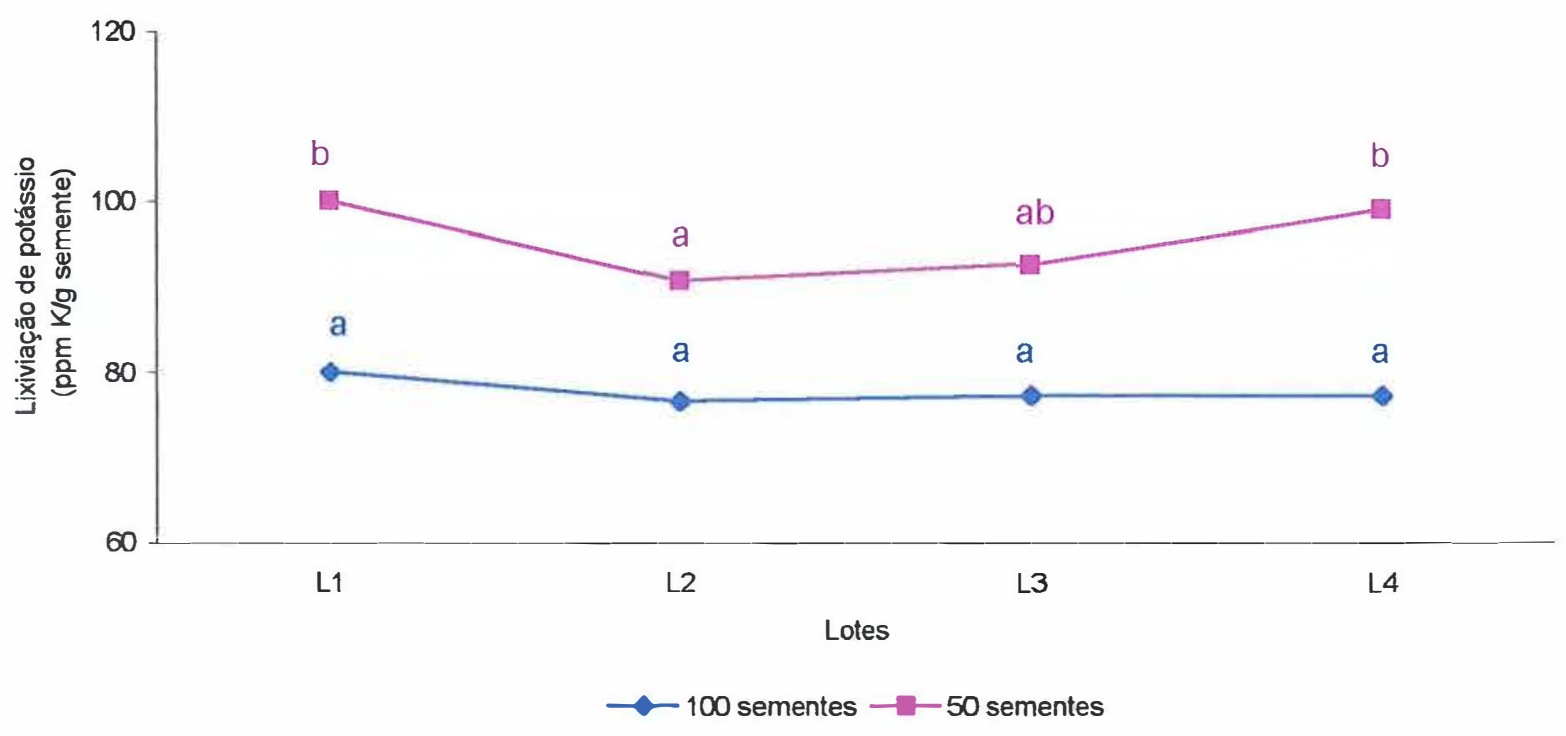

Figura 79. Híbrido Traktor: influência do número de sementes na lixiviação de potássio, mantendo-se constantes volume $(75 \mathrm{ml})$ e período de embebição (90 minutos).

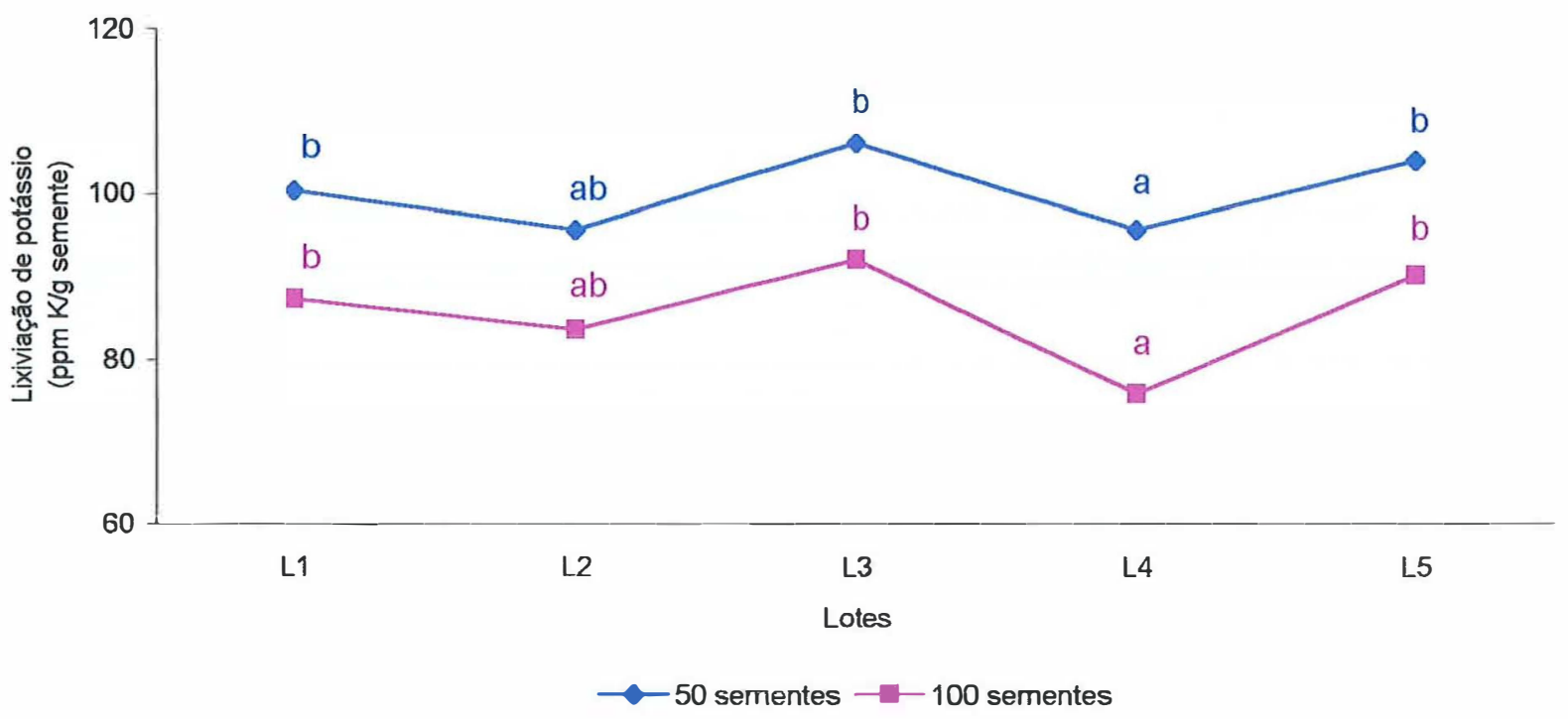


Nas Figuras 77, 78 e 79 percebe-se nitidamente que a alteração apenas do número de sementes, mantendo-se constantes as outras variáveis (período, volume de embebição e temperatura), geralmente provocou redução da lixiviação de potássio, fato não observado por Custódio e Marcos Filho (1997). Os tratamentos com o menor número de sementes apresentou maiores lixiviações de potássio do que aqueles com maior número de sementes.

Uma possível explicação para esse fato seria a de que um maior número de sementes entraria mais rapidamente em equilíbrio osmótico com a solução de embebição e, ao se aproximar do equilíbrio a lixiviação se tornaria mais lenta; ou ainda, a possibilidade de um menor número de sementes apresentar maior área de exposição a água durante o período de embebição e conseqüente aumento da exsudação de potássio.

\subsubsection{Volume de embebição}

A lixiviação de potássio pelas sementes de milho não manteve relação direta com a diminuição do volume de água; a redução do volume de água, quando se mantiveram constantes os outros fatores (número de sementes, temperatura e período de embebição), não estabeleceu, em geral, relação direta com o aumento do valor da lixiviação de potássio, provavelmente, pelo mesmo motivo mencionado item anterior, ou seja, o mesmo número de sementes em um volume de água menor entraria em equilíbrio com a solução de embebição mais rapidamente, provocando valores menores de lixiviação de potássio.

Essa tendência foi observada nos três híbridos estudados (Figuras 80, 81 e 82); os valores de lixiviação no maior volume foram superiores ou próximos do tratamento com menor volume. No entanto, Loeffler (1981), observou maiores valores de lixiviados em menores volumes e atribuiu ao fato de que a embebição em um volume maior de água implica em maior diluição dos lixiviados. 
Figura 80. Híbrido Avant: Influência da diminuição do volume de água na lixiviação de potássio, mantendo-se constantes o número de sementes (50) e o período de embebição (60 minutos).

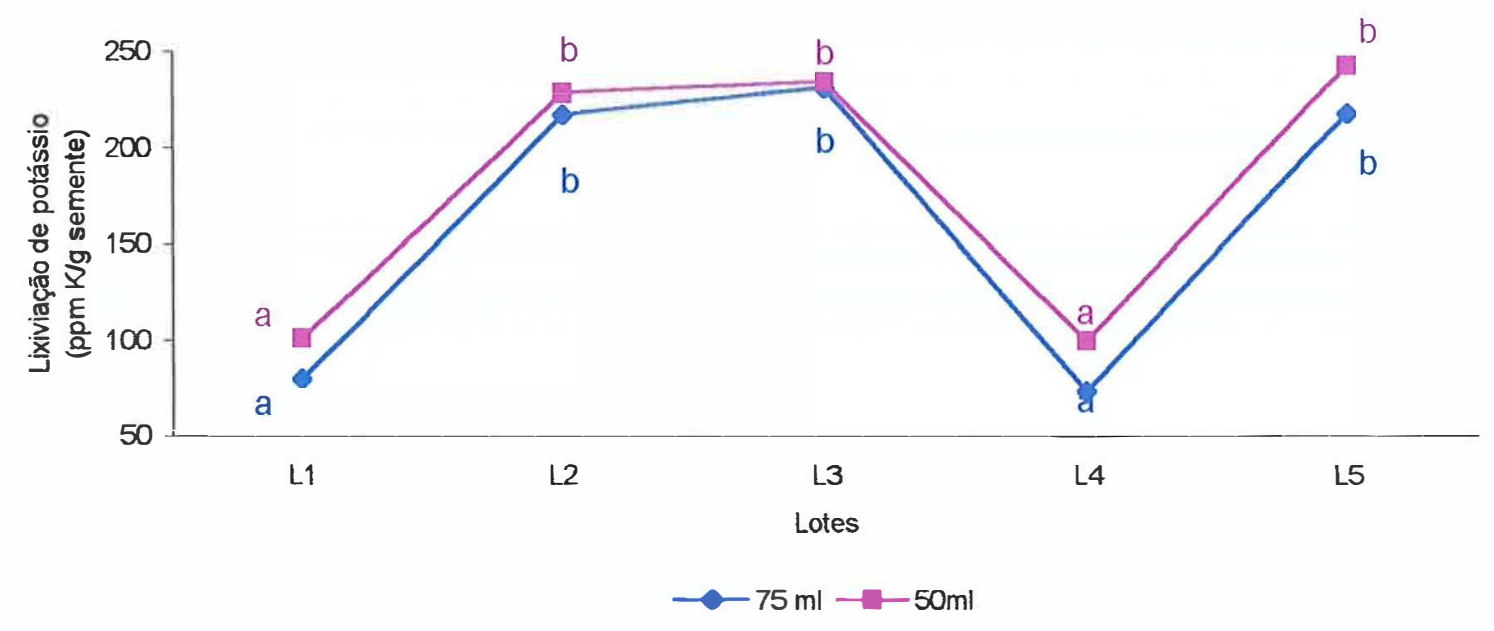

Figura 81. Híbrido AG 6690: influência da diminuição do volume de água na lixiviação de potássio, mantendo-se constantes o número de sementes (50) e o período de embebição (60 minutos).

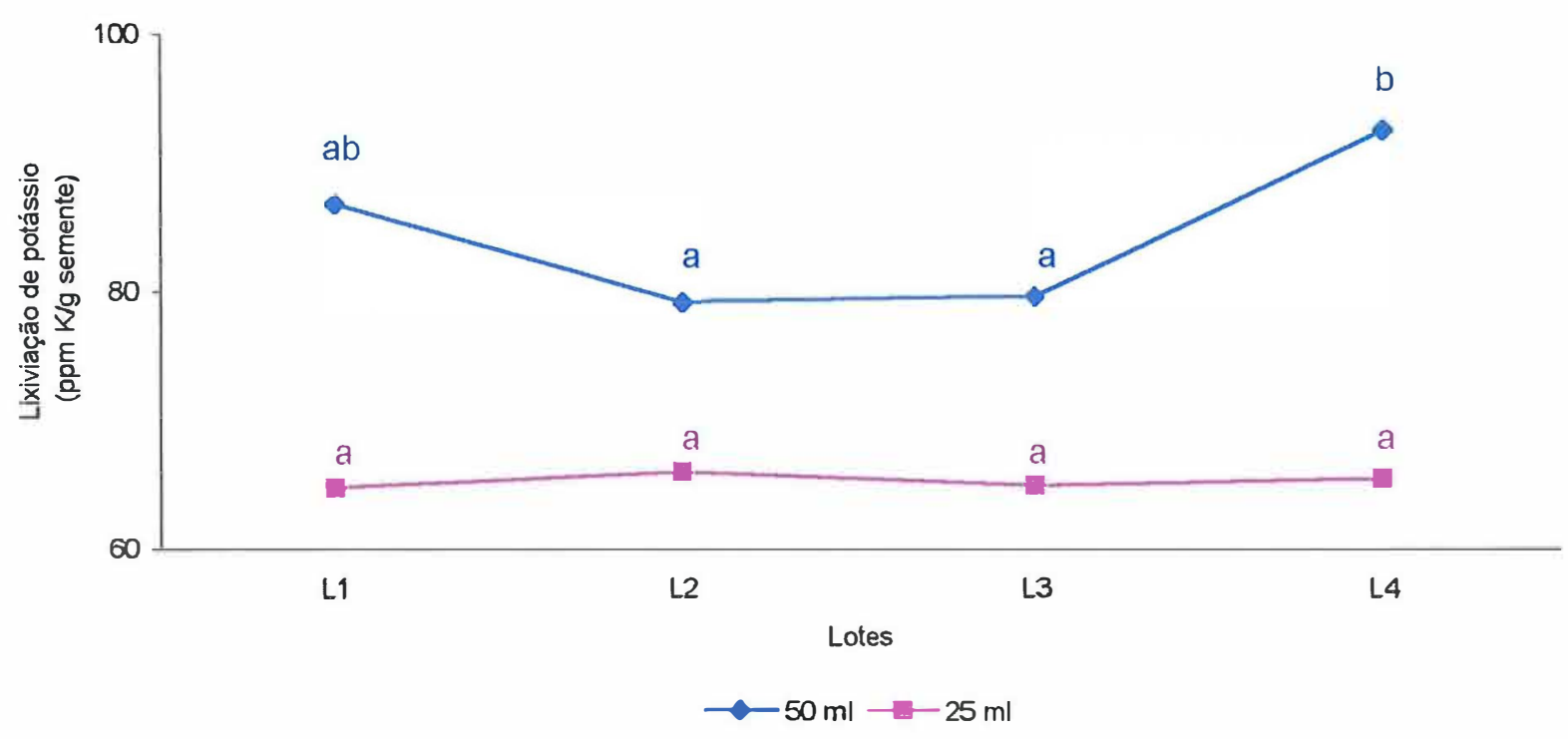


Figura 82. Híbrido Traktor: influência da diminuição do volume de água na lixiviação de potássio, mantendo-se constantes o número de sementes (50) e o período de embebição (60 minutos).

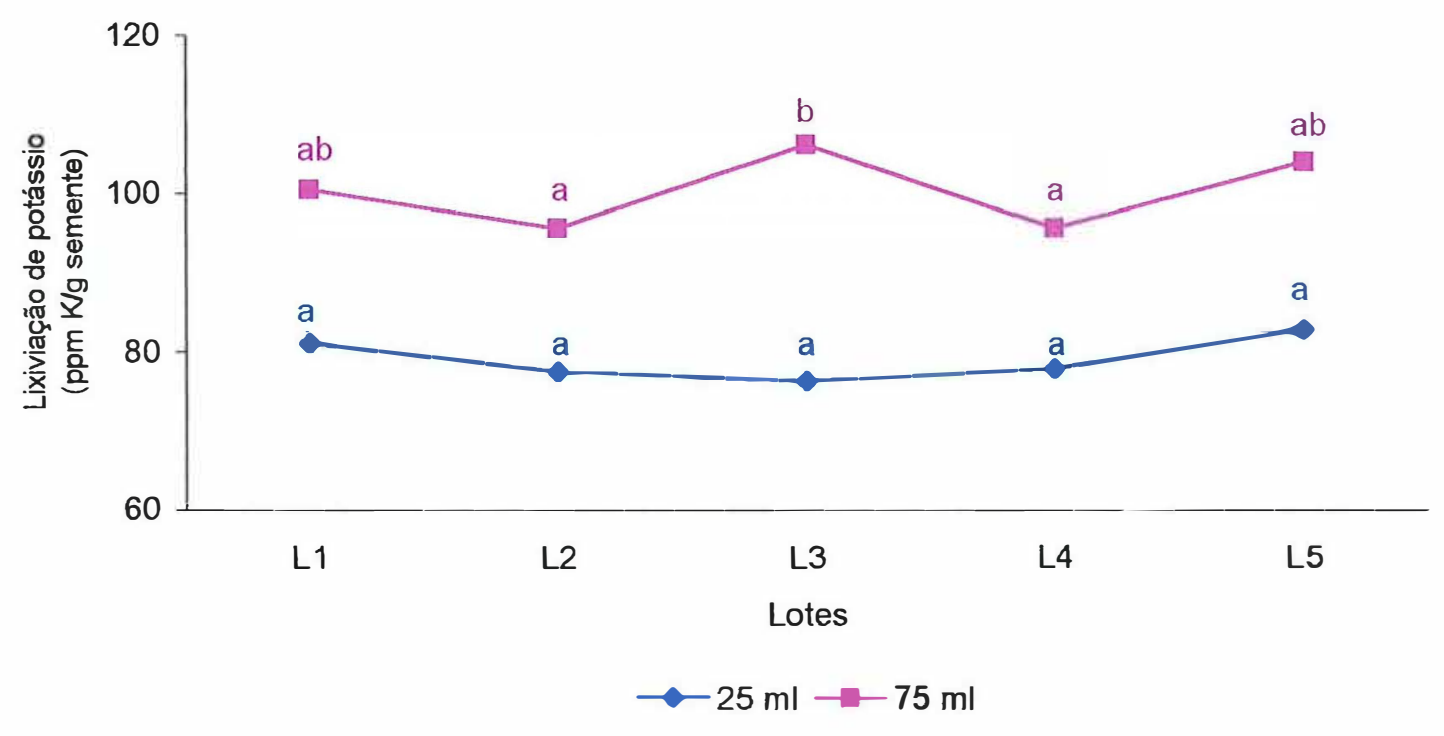

\subsubsection{Considerações Gerais}

As relações observadas entre as variações no período de embebição, no número de sementes, no volume de embebição e na temperatura, com os valores de lixiviação de potássio foram as mesmas para os híbridos Avant, AG 6690 e Traktor.

Dessa forma, pode-se dizer que as tendência das sementes de milho, em relação a lixiviação de potássio, dentro de um mesmo tratamento, são em geral as seguintes: a lixiviação de potássio aumenta com o período de embebição; o aumento do número de sementes proporciona valores mais baixos de lixiviação de potássio; a redução do volume de embebição não proporciona a obtenção de valores mais altos de lixiviação de potássio; a diferença de $5^{\circ} \mathrm{C}$ entre as temperaturas $\left(25^{\circ} \mathrm{C}\right.$ e $\left.30^{\circ} \mathrm{C}\right)$, não foi suficiente para aumentar a lixiviação de potássio pelas sementes. 
Verifica-se, portanto, que é essencial para a eficiência do teste de lixiviação de potássio na determinação do potencial fisiológico de sementes de milho, a combinação adequada entre período de embebição, número de sementes, volume de água de embebição e temperatura.

Assim, a combinação deve ser tal que as sementes tenham condições de lixiviar uma quantidade adequada de potássio, no menor período possível, para avaliação correta do potencial fisiológico dos lotes.

Apesar das tendências terem sido as mesmas nos três híbridos, cada um respondeu de maneira particular aos diferentes tratamentos. Esse fato sugere que a definição dos parâmetros período de embebição, número de sementes, volume de embebição e temperatura, devem ser feitos para cada híbrido.

\subsection{Análise química das sementes e das soluções de embebição}

Os resultados das análises químicas das sementes e das soluções de embebição, estão nas Tabelas 3 e 4, respectivamente.

A análise da composição química dos lotes foi feita com o intuito de verificar se os resultados da lixiviação de potássio poderiam ser influenciados pela concentração de potássio nas sementes. Essa observação pode oferecer maior segurança na interpretação dos resultados obtidos, pois é desejável que a composição química das sementes avaliadas não tenha influência nos resultados do teste de lixiviação de potássio.

Como pode ser observado na Tabela 3 , a quantidade de potássio presente nas sementes não interferiu nos resultados do teste. Em alguns casos os lotes indicados como superiores tinham maiores quantidades de potássio em sua composição química, do que aqueles apontados como inferiores, como por exemplo, no caso do híbrido Avant em que o lote 1 considerado o mais vigoroso foi o que apresentou maior quantidade de potássio em sua composição, não havendo portanto relação entre a composição química das sementes e a exsudação de potássio. 
Outra preocupação em relação ao teste seria a de que ao se determinar potássio na verdade estaria se quantificando simultaneamente proteína. No entanto, não se observou relação direta entre a quantidade de potássio e de proteína. Panobianco (2000), também verificou que em sementes de tomate o potássio determinado não estava associado a proteínas.

A análise da composição química da solução (Tabela 4) mostrou a precisão da quantificação do potássio pelo fotômetro de chama, pois ao confrontar-se os dados do teste de lixiviação de potássio com a quantidade de potássio analisada quimicamente, verificamos que foram coincidentes, ou seja, os lotes foram classificados da mesma maneira, comprovando-se mais uma vez a não interferência da proteína nas avaliações.

Outra resposta interessante foi referente à análise da água de embebição, que possibilitou verificar que a quantidade de potássio é zero, não tendo nenhuma influência nos resultados de lixiviação de potássio.

Portanto, no presente trabalho desconsiderou-se a interferência das variáveis composição química das sementes e da água destilada nos resultados do teste de lixiviação de potássio. 
Tabela 3. Composição química, dos lotes de sementes de milho, dos híbridos Avant, AG 6690 e Traktor.

\begin{tabular}{|c|c|c|c|c|c|c|}
\hline & $\mathrm{N}$ & $\mathbf{P}$ & $\mathbf{K}$ & $\overline{\mathrm{Ca}}$ & $\mathrm{Mg}$ & 5 \\
\hline Híbrido/lote & 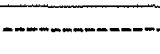 & $\ldots$ & $-g / \mathrm{kg}$ & $+\cdots$ & (n) & \\
\hline Avant/1 & 17,64 & 8,06 & 6,38 & 0,05 & 2,58 & 0,86 \\
\hline Avant/2 & 12,18 & 2,67 & 2,81 & 0,05 & 1,12 & 0,85 \\
\hline Avant/3 & 12,04 & 2,38 & 2,55 & 0,05 & 0,88 & 0,78 \\
\hline Avant/4 & 13,86 & 3,79 & 3,57 & 0,05 & 1,36 & 1,02 \\
\hline Avant/5 & 15,12 & 4,94 & 4,59 & 0,05 & 1,86 & 0,78 \\
\hline Traktor/1 & 15,96 & 4,03 & 3,57 & 0,05 & 1,56 & 0,95 \\
\hline Traktor/2 & 15,40 & 6,84 & 5,87 & 0,05 & 2,67 & 0,84 \\
\hline Traktor/3 & 16,66 & 3,41 & 3,06 & 0,05 & 1,47 & 0,83 \\
\hline Traktor/4 & 14,70 & 4,04 & 3,83 & 0,05 & 1,72 & 1,00 \\
\hline Traktor/5 & 13,44 & 2,09 & 2,04 & 0,05 & 0,81 & 0,78 \\
\hline AG 6690/1 & 16,24 & 3.90 & 3,32 & 0,05 & 1,36 & 0,83 \\
\hline AG $6690 / 2$ & 16,94 & 3,81 & 3,57 & 0,05 & 1,43 & 0,87 \\
\hline AG 6690/3 & 17,64 & 3,69 & 3,32 & 0,05 & 1,33 & 0,89 \\
\hline \multirow[t]{2}{*}{ AG 6690/4 } & 16,94 & 3,66 & 3,32 & 0,10 & 1,34 & 0,80 \\
\hline & B & $\mathrm{Cu}$ & $\mathrm{Fe}$ & $\mathrm{Mn}$ & $\mathrm{Zn}$ & \multirow{2}{*}{$\begin{array}{c}\text { Proteína } \\
--\mathrm{g} / \mathrm{kg}--\end{array}$} \\
\hline Hibrido/lote & $\cdots$ & - & 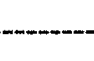 & 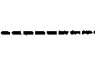 & & \\
\hline Avant/1 & 7,4 & 2,3 & 73,4 & 11,8 & 51,7 & 110,25 \\
\hline Avant/2 & 4,5 & 0,9 & 46,6 & 5,4 & 21,6 & 76,13 \\
\hline Avant/3 & 7,9 & 0,6 & 42,7 & 7,1 & 17,4 & 75,25 \\
\hline Avant/4 & 4,3 & 1,4 & 52,4 & 7,9 & 30,8 & 86,63 \\
\hline Avant/5 & 5,4 & 2,3 & 69,9 & 6,7 & 36,4 & 94,50 \\
\hline Traktor/1 & 5,2 & 3,0 & 62,9 & 8,4 & 32,3 & 99,75 \\
\hline Traktor/2 & 4,3 & 2,3 & 79,6 & 10,8 & 52,0 & 96,25 \\
\hline Traktor/3 & 5,0 & 1,5 & 52,9 & 8,3 & 28,8 & 104,13 \\
\hline Traktor/4 & 8,3 & 2,4 & 59,7 & 10,0 & 34,2 & 91,88 \\
\hline Traktor/5 & 4,5 & 2,4 & 47,5 & 5,3 & 16,9 & 84,00 \\
\hline AG 6690/1 & 7,0 & 2,8 & 56,9 & 5,6 & 30,7 & 101,50 \\
\hline AG $6690 / 2$ & 6,3 & 4,1 & 58,6 & 8,1 & 32,0 & 105,88 \\
\hline AG $6690 / 3$ & 6,5 & 3,1 & 53,5 & 6,7 & 30,1 & 110,25 \\
\hline AG 6690/4 & 7,0 & 4,2 & 53,8 & 5,2 & 31,0 & 105,88 \\
\hline
\end{tabular}


Tabela 4. Composição química, da solução de embebição das sementes de milho, dos híbridos Avant, AG 6690 e Traktor e da água destilada utilizada para embeber as sementes.

\begin{tabular}{|c|c|c|c|c|c|}
\hline Híbrido/lote & $\mathrm{Na}$ & $P$ & $\bar{K}$ & $\mathrm{Ca}$ & $\mathrm{Mg}$ \\
\hline Avant/1 & 0,7 & 4,98 & 13,20 & traços & 0,09 \\
\hline Avant/2 & 0,2 & 8,67 & 32,40 & traços & 0,26 \\
\hline Avant/3 & 0,5 & 11,63 & 35,40 & traços & 0,26 \\
\hline Avant/4 & 0,4 & 5,35 & 14,40 & traços & 0,13 \\
\hline Avant/5 & 0,4 & 9,78 & 30,60 & traços & 0,19 \\
\hline Traktor/1 & 0,4 & 2,95 & 12,60 & traços & 0,06 \\
\hline Traktor/2 & 0,3 & 2,21 & 13,20 & traços & 0,07 \\
\hline Traktor/3 & 0,4 & 3,32 & 13,20 & traços & 0,16 \\
\hline Traktor/4 & 0,5 & 2,40 & 10,80 & traços & 0,05 \\
\hline Traktor/5 & 0,4 & 2,95 & 13,80 & traços & 0,12 \\
\hline AG 6690/1 & 0,9 & 7,57 & 22,20 & traços & 0,11 \\
\hline$A G 6690 / 2$ & 0,7 & 7,38 & 21,00 & traços & 0,11 \\
\hline$A G 6690 / 3$ & 0,6 & 5,72 & 18,60 & traços & 0,11 \\
\hline$A G 6690 / 4$ & 0,5 & 3,51 & 10,80 & traços & 0,12 \\
\hline $\mathrm{H}_{2} \mathrm{O}$ destilada & 0,3 & 0,92 & zero & traços & 0,10 \\
\hline Híbrido/lote & B & $\mathrm{Cu}$ & Fe & $M n$ & $\mathrm{Zn}$ \\
\hline Avant/1 & 0,02 & traços & traços & traços & 0,12 \\
\hline Avant/2 & 0,23 & traços & traços & traços & 0,12 \\
\hline Avant/3 & 0,05 & traços & traços & traços & 0,11 \\
\hline Avant/4 & 0,18 & traços & traços & traços & 0,06 \\
\hline Avant $/ 5$ & 0,12 & traços & traços & traços & 0,08 \\
\hline Traktor/1 & 0,06 & traços & traços & traços & 0,08 \\
\hline Traktor $/ 2$ & - & traços & 0,002 & 0,004 & 0,15 \\
\hline Traktor/3 & 0,11 & traços & traços & traços & 0,12 \\
\hline Traktor/4 & 0,16 & traços & traços & 0,004 & 0,12 \\
\hline Traktor/5 & 0,02 & traços & traços & traços & 0,08 \\
\hline AG6690/1 & 0,13 & traços & traços & traços & 0,13 \\
\hline AG6690/2 & 0,24 & traços & traços & traços & 0,06 \\
\hline
\end{tabular}




\begin{tabular}{|c|c|c|c|c|c|}
\hline \multicolumn{6}{|l|}{ Continuação } \\
\hline Híbrido/lote & B & $\mathrm{Cu}$ & $\mathrm{Fe}$ & Mn & $\mathrm{Zn}$ \\
\hline AG6690/3 & 0,40 & traços & traços & traços & 0,07 \\
\hline AG6690/4 & 0,23 & traços & 0,02 & traços & 0,11 \\
\hline $\mathrm{H}_{2} \mathrm{O}$ destilada & - & traços & traços & traços & 0,04 \\
\hline
\end{tabular}

- quantidade insuficiente para determinação 


\section{CONCLUSÕES}

A análise dos dados e a interpretação dos resultados permitiram concluir que:

1) O teste de lixiviação de potássio, utilizando-se a combinação de 50 sementes $/ 75 \mathrm{ml}$ de água/90 minutos de embebição, a $25^{\circ} \mathrm{C}$, constitui alternativa promissora para deteç̧ão de diferenças acentuadas no potencial fisiológico de sementes de milho.

2) A materialização de uso rotineiro desse teste para avaliação do vigor de sementes de milho depende da evolução da pesquisa rumo à padronização de procedimentos, considerando-se, inclusive, os prováveis efeitos do genótipo. 


\section{REFERÊNCIAS BIBLIOGRÁFICAS}

ABDEL SAMAD, I.M.; PEARCE, R.S. Leaching of ions, organic molecules and enzymes from seeds of peanut (Arachis hipogaea L.) imbibing without testas or with intact testas. Journal of Experimental Botany. v.29, n.113, p.14711478, 1978.

ABDUL-BAKI, A.A.; BAKER, J.E. Are changes in cellular organelles or membranes related to vigor loss in seeds. Seed Science and Technology, v.1, n.1, p.89-125, 1973.

AGUILAR, R.; REYMOSO, E.; ALBORES, M.; SANCHEZ-DE JIMENEZ, E. Changes in protein synthesis in embryonic axes after long term storage of maize seeds. Seed Science Research, v. 2, n.4, p.191-198, 1991.

AMORIM, H.V. Aspectos bioquímicos e histoquímicos do grão do café verde relacionados com a deterioração da qualidade. Piracicaba, 1978. 85p. Tese (Livre-Docência) - Escola Superior de Agricultura "Luiz de Queiroz", Universidade de São Paulo.

ANDERSON, J.D. Metabolic changes associated with senescence. Seed Science and Technology, v.1, n.2, p.401-416, 1973. 
ASSOCIATION OF OFFICIAL SEED ANALYSTS - AOSA. Seed vigor testing handbook. East Lasing: AOSA, 1983. 93p. (Contribution, 32).

BARROS, A.S.R.; MARCOS FILHO, J. Testes para avaliação rápida da viabilidade de sementes de soja. Pesquisa Agropecuária Brasileira. v.25, n.10, p.1447-1459, 1988.

BECWAR, M.R.; STANWOOD, P.C.; ROOS, E.E. Dehydration effects on imbibitional leakage from desiccation - sensitive seeds. Plant Physiology, v. 69, n. 5 , p. $1132-1135,1982$.

BERJAK, P.; DINI, M.; GEVERS, H.O. Deteriorative changes in embryos of long-stored, uninfected maize caryopses. South African Journal of Botany, v.52, p.109-111, 1986.

BEWLEY, J.D. Membrane changes in seeds as related to germination and the perturbations resulting from deterioration in storage. In: McDONALD, M.B.; NELSON, C.J. (Eds.). Physiology of seed deterioration. Madison: Crop Society of America. p.27-47. 1986.

BEWLEY, J.D.; BLACK, M. Seed. Physiology of development and germination. New York: Plenum Press, 1994. 444p.

BRASIL. Ministério da Agricultura. Regras para análise de sementes. Brasília, 1992. $365 p$.

BRIGANTE, G.P. Efeitos da época e da localização da colheita na qualidade fisiológica de sementes de algodão (Gossipium hirsutum L.). Lavras, 1988. 113p. Dissertação (M.S.) Universidade Federal de Lavras. 
BRUGGINK, H.; KRAAK, H.L.; DIJEMA, M.H.G.E.; BEKEDAM, J. Some factors influencing eletrolyte leakage from maize (Zea mays L.) kernels. Seed Science Research, v.1, p.15-20, 1991.

CARVALHO, M.V.; SPINOLA, M.C.M; MARCOS FILHO, J. Lixiviação de potássio na avaliação da qualidade fisiológica de sementes de milho In: CONGRESSO BRASILEIRO DE SEMENTES, 11. Foz do Iguaçu, 1999. Anais. Curitiba, ABRATES, 1999, p.130.

CARVALHO, N.M. O conceito de vigor em sementes. In: VIEIRA, R.D.; CARVALHO, N.M. Testes de vigor em sementes. Jaboticabal: FUNEP. 1994. p.1-30.

CARVALHO, N.M.; NAKAGAWA, J. Sementes: ciência, tecnologia e produção. 4 ed. Jaboticabal: Funep, 2000, 588 p.

CHAUHAN, K.P.S. The incidence of deterioration and its localization in aged seeds of soybean and barley. Seed Science and Technology, v.13, n.2, p.769-773, 1985.

CHERRY, J.H.; SKADSEN, R.W. Nucleic acid and protein metabolism during seed deterioration. In: McDONALD, M.B., NELSON, C.J. Physiology of seed deterioration, CSSA, p. 65-87, 1983.

CUSTÓDIO, C.C.; MARCOS FILHO, J. Potassium leakage test for the evaluation of soybean seed physiological quality. Seed Science and Technology, v.25, n.3, p. 549-564, 1997.

DELOUCHE, J.C. Standardization of vigor tests. Journal of Seed Technology, v.1, n.2, p.75-86, 1976. 
DELOUCHE, J.; BASKIN, C.C. Accelerated aging techniques for predicting the relative storability of seed lots. Seed Science and Technology, v.1, n.1, p. 427-452, 1973.

DeROBERTIS, E.D.P.; DeROBERTIS Jr., E.M.F. Bases da biologia celular e molecular. Rio de Janeiro, Ed. Guanabara, 1981, 332 p.

DIAS, D.C.F.S.; MARCOS FILHO, J. Testes de vigor baseados na permeabilidade de membranas celulares: 1. Condutividade elétrica. Informativo ABRATES, v.5, n.1, p. 26-36, 1995.

DIAS, D.C.F.S.; MARCOS FILHO, J.; CARMELLO, Q.A.C. Potassium leakage test for the evaluation of vigour in soybean seeds. Seed Science and Technology, v.25, n.1, p. 7-18, 1996.

DONI FILHO, L. Efeitos do condicionamento fisiológico no comportamento de sementes de feijão (Phaseolus vulgaris L.). Piracicaba, 1992. 108p. Tese (Doutorado) - Escola Superior de Agricultura "Luiz de Queiroz", Universidade de São Paulo.

DUKE, S.H.; KAKEFUDA, G. HARVEY, T.M. Differential leakage of intracellular substances from imbibing soybean seeds. Plant Physiology, v. 72, n. 4, p. 919-924, 1983.

FRAGA, A.C. Eficiência do teste de condutividade elétrica para predizer a qualidade fisiológica de sementes de algodão. In: REUNIÃO NACIONAL DE ALGODÃO, 5. Campina Grande, 1988. Resumos. Campina Grande, EMBRAPA-CNPA, 1988, p.120. 
GANGULI, S.; SEN-MANDI, S. Some physiological differences between naturally and artificially aged wheat seeds. Seed Science and Technology, v.18, p.507-514, 1990.

GIVELBERG, A.; HOROWITZ, M.; POLJAKOFF-MAYBER, A. Solute leakage from Solanum nigrum $L$. seeds exposed to high temperatures during imbibition. Journal of Experimental Botany, v.35, n.161, p.1754-1763, 1984.

GORECKI, R.J.; HARMAN, G.E.; MATTICK, L.R. The volatile exudates from germinating pea seeds of different viability and vigor. Canadian Journal of Botany, v.63, n.6, p.1035-1039, 1985.

GRANQVIST, G.A. Leakage of cations from a carrot seed lot. Acta Horticultural, v.215, p.219-224, 1987.

HALLOIN, J.M. Solute loss from deteriorated cotton seed: relationship between deterioration, seed moisture, and solute loss. Crop Science. v.15, n.1, p.11$15,1975$.

HAMPTON, J.G. Conductivity test. In: VAN DER VENTER, H.A. (Ed.). Seed Vigour Test Seminar. Zurich: International Test Association. p.10-28, 1995.

JAMES, E. Preservation of seeds stocks: Advances in Agronomy, v.19, p.87106, 1967.

KHAN, M.M.; HENDRY, G.A.; ATHERTON, N.M.; WALTERS, C.W. Free radical accumulation and lipid peroxidation in tests of rapidly aged soybean seeds; a light promoted process. Seed Science Research, v. 6, n.3, p.101-107, 1996. 
KRYZANOWSKI, F.C.; FRANÇA NETO, J.B.; HENING, A.A. Relato dos testes de vigor disponiveis para as grandes culturas. Informativo ARATES, v.1, n.2, p. 15-50, 1991.

KULIK, M.M; YAKLICH, R.W. Evaluation for vigor tests in soybean seeds relationship of accelerated aging, cold, sand bench and speed of germination tests to field performance. Crop Science, v. 22, n. 4, p. 766-770, 1982.

LARSON, L.A. The effect soaking pea seeds with or without seed coats has on seedling growth. Plant Physiology, v. 43, n.2, p. 255-259, 1968.

LEOPOLD, A.C. Temperature effects on soybean imbibition and leakage. Plant Physiology, v. 65, n.4, p.1096-1098, 1980.

LEE, C.K.; KARUNANITHY, R. Effects of germination on the chemical composition of Glycine and Phaseolus beans. Journal Science Food Agriculture. v.51, n.4, p.437-445, 1990.

LIN, S.S. Efeito do período de armazenamento na lixiviação eletrolítica dos solutos celulares e qualidade fisiológica da semente de milho (Zea mayz L.) e feijão (Phaseolus vulgaris L.). Revista Brasileira de Sementes, v. 10, n.3, p. 59-67, 1988.

LOEFFLER, T.M. The bulk conductivity testan indicator of soybean seed quality. Lexington, 1981. 181p. Dissertação (M.S.) - University of Kentucky.

LOEFFLER, T.M.; TEKRONY, D.M.; EGLI, D.B. The bulk conductivity test as an indicator of soybean seed quality. Journal Seed Technology, v.12, n.1, p.37-53, 1988. 
LOOMIS, E.L.; SMITH, O.E. The effect of artificial ageing on the concentration of $\mathrm{Ca}, \mathrm{Mg}, \mathrm{Mn}, \mathrm{K}$, and $\mathrm{Cl}$ in imbibing cabbage seed. Journal American Society Horticultural Science. v.105, n.5, p.647-650, 1980.

LOTT, J.N.A.; CAVDEK, V.; CARSON, J. Leakage of $\mathrm{K}, \mathrm{Mg}, \mathrm{Cl}, \mathrm{Ca}$ and $\mathrm{Mn}$ from imbibing seeds grains and isolated seed parts. Seed Science Research. v.8, p.229-233, 1991.

LUZZATI, V.; HUSSON, F. The structure of the liquid - crystalline phases of lipid - water systems. Journal of Cell Biology, v.12, n.2, p.207-220, 1962.

MARCOS FILHO, J. Qualidade fisiológica e maturação de sementes de soja (Glycine max (L.) Merrill). Piracicaba, 1979. 180p. Tese (Livre-Docência) Escola Superior de Agricultura "Luiz de Queiroz", Universidade de São Paulo.

MARCOS FILHO, J. O valor dos testes de vigor. Seed News, n.6, p.32, jul/ago. 1998.

MARCOS FILHO, J. Testes de vigor: Importância e utilização. In: KRZYZANOWSKI, F.C.; VIEIRA, R.D.; FRANÇA NETO, J.B. (Eds.). Vigor de Sementes: Conceitos e Testes. Londrina: ABRATES, 1999a. cap.1, p.1-21.

MARCOS FILHO, J. Teste de envelhecimento acelerado. In: KRZYZANOWSKI, F.C.; VIEIRA, R.D.; FRANÇA NETO, J.B. (Ed.). Vigor de Sementes: Conceitos e Testes. Londrina: ABRATES, 1999b. cap.3, p.1-24.

MARCOS FILHO, J.; AMORIM, H.V.; SILVAROLLA, M.B.; PESCARIM, H.M.C. Relações entre germinação, vigor e permeabilidade das membranas 
celulares durante a maturação de sementes de soja. In: SEMINÁRIO NACIONAL DE PESQUISA DE SOJA, 2, Brasília, 1981. Anais. Londrina: EMBRAPA/CNPSo, p. 676-683, 1982.

MARCOS FILHO, J.; PESCARIM, H.M.C.; KOMATSU, Y.H.; DEMÉTRIO, C.G.B.; FANCELLI, A.L. Testes para avaliação do vigor de sementes de soja e sua relação com emergência de plântulas em campo. Pesquisa Agropecuária Brasileira. v.19, n.5, p.605-613, 1984.

MARCOS FILHO, J.; CARVALHO, R.V.; CICERO, S.M.; DEMÉTRIO, C.G.B. Qualidade fisiológica e comportamento de sementes de soja (Glycine max (L.) Merril) no armazenamento e no campo. Anais da Escola Superior de Agricultura "Luiz de Queiroz". v.42, p.195-249, 1985.

MARCOS FILHO, J.; CARVALHO, R.V.; CICERO, S.M.; DEMÉTRIO, C.G.B. Qualidade fisiológica e comportamento de sementes de soja no armazenamento e no campo. Anais da Escola Superior de Agricultura "Luiz de Queiroz". v.43, p.389-443, 1986.

MARCOS FILHO, J.; CICERO, S.M.; SILVA, W.R. Avaliação da qualidade de sementes. Piracicaba: FEALQ, 1987. 230p.

MARCOS FILHO, J.; SILVA, W.R.; NOVEMBRE, A.D.C.; CHAMMA, H.M.C.P. Estudo comparativo de métodos para avaliação da qualidade fisiológica de sementes de soja, com ênfase ao teste de condutividade elétrica. Pesquisa Agropecuária Brasileira. v.25, n.12, p.1805-1815, 1990.

MATTHEWS, S. Evaluation of techniques for germination and vigor studies. Seed Science and Technology, v.9, p.543-551, 1981. 
MATTHEWS, S; ROGERSON, N.E. The influence of embryo condition on the leaching of solutes from pea seeds. Journal of Experimental Botany. v.27, n.100, p.961-968, 1976.

McDONALD, M. B. Seed quality assessment. Seed Science Research. v.8, p.265-275, 1998.

MCDONALD, M. B. Seed deterioration: physiological, repair and assessment. Seed Science and Technology, v.27, p.177-237, 1999.

MCDONALD, M. B.; WILSON, D.O. An assessment of the standardization and ability of the ASA-610 to rapidly predict potential soybean germination. Journal of Seed Technology, v.4, n.2, p.1-11, 1979.

McGEE, D.C. Introduction. In: Symposium on deterioration mechanisms in seeds. Phytopatology, v.73, n.2, p. 314-17, 1983.

MCKERSIE, B.D.; STINSON, R.H. Effect of dehydration on leakage and membrane structure in Lotus corniculatus L. seeds. Plant Physiology, v. 66, p. 316-320, 1980.

MOSS, G.I.; MULLETT, J.H. Potassium release and seed vigour in germinating (Phaseolus vulgaris L.) seed as influenced by temperature over the previous five generations. Journal Experimental Botany. v.33, n.137, p.1147-1160, 1982.

MURPHY, J.B.; NOLAND, T.L. Temperature effects on seed imbibition and leakage mediated by viscosity and membranes. Plant Physiology. v.69, n.2, p.428-431, 1982. 
MURRAY, D.R. Axis - cotyledon relationships during reserve mobilization. In: MURRAY, D.R. Seed Physiology, Academy Press, 1984, 295p.

OLIVEIRA, J.A. Correlação entre evolução de hexanal e de aldeídos totais, a lixiviação de ions e o potencial de germinação de sementes de soja (Glycine $\max$ (L.) Merril). Viçosa, 1990. 79p. Dissertação (M.S.) - Universidade Federal de Viçosa.

OSBORNE, D.J. Senescence in seeds. In: Senescence in plants, 1980. In: PETER COOLBEAR. Mechanisms of seed deterioration. In BASRA, A.S. Seed quality: basic mechanisms and agricultural implications. p.223-277, 1995.

PANDEY, D.K. Ageing of French bean seeds at ambient temperature in relation to vigour and viability. Seed Science and Technology. v.17, n.1, p.41-47, 1989.

PANOBIANCO, M. Avaliação do potencial fisiológico de sementes de tomate. Piracicaba, 2000. 152p. Tese (Doutorado) - Escola Superior de Agricultura "Luiz de Queiroz", Universidade de São Paulo.

PARRISH, D.J.; LEOPOLD, A.C. Transient changes during soybean imbibition. Plant Physiology, v. 59, n. 6, p. 1111-1115, 1977.

POWEL, A.A. Cell membranes and seeds leachate conductivity in relation to the quality of seed for sowing. Journal of Seed Technology, v.10, n.2, p.81100, 1986.

POWEL, A.A.; MATTHEWS, S. Association of phospholipid changes with early stages of seed ageing. Annals of Botany. v.47, n.5, p.709-712, 1981. 
POWEL, A.A.; OLIVEIRA, M.D.A.; MATTHEWS, S. The role of imbibition damage in determining the vigour of the White and coloured seed lots of dwarf French beans (Phaseolus vulgaris). Joumal of Experimental Botany. v.37, n.178, p.716-722, 1986.

PRETE, C.E.C. Condutividade elétrica do exsudato de grãos de café (Coffea arábica L.) e sua relação com a qualidade da bebida. Piracicaba, 1992. 125p. Tese (Doutorado) - Escola Superior de Agricultura "Luiz de Queiroz", Universidade de São Paulo.

QUEIROGA, V.P.; PARRA, N.R. Análises de eletrólitos nos exsudatos de sementes de girassol (Heliantus annus L.) In: CONGRESSO BRASILEIRO DE SEMENTES, 6, Brasília, 1989. Resumos. Brasília: ABRATES, 1989. $66 p$.

RODELLA, A.A. \& BORGES, M.T.M.R. Manual básico para o laboratório sucro-alcooleiro. Piracicaba, 1989. 225p.

SANTOS, C.M. Influência do controle do crescimento, do uso de fungicidas e da freqüência de colheita, nos caracteres agronômicos e na qualidade da fibra e da semente de algodoeiro (Gossipium hirsutum L.). Viçosa, 1993. 184p. Tese (Doutorado) Universidade Federal de Viçosa.

SARRUGE, J.R. \& HAAG, H.P. Análises químicas em plantas. Piracicaba, ESALQ, 1974.55p.

SCHOETTLE, A.W.; LEOPOLD, A.C. Solute leakage from artificially aged soybean seeds after imbibition. Crop Science, v. 24, n. 5, p. 835-838, 1984. 
SIMON, E.W.; MATHAVAN, S. The time time-course of leakage from imbibing seeds of different species. Seed Science and Technology, v.14, n. 1, p.9$13,1986$.

SIMON, E.W.; RAJA HARUN, R.M. Leakage during seed imbibition. Journal of Experimental Botany. v.23, n.77, p.1076-1085, 1972.

SREERAMULU, N. Leakage during imbibition by seeds of bambana groundnut (Voandzeia subterranea (L.) Thouars) at different stages of loss of viability. Tropical Agriculture. v.60, n.4, p.265-268, 1983.

STOECKENIUS, W. Some electron microscopial observations on liquid crystalline phases in liquid - water systems. Journal of Cell Biology, v.12, n.2, p.221-229, 1962.

STYER, R.; CANTLIFFE, D.J. Dependence of seed vigor during germination on carbohydrate source in endosperm mutants of maize. Plant Physiology, v. 76, p. 196-200, 1984.

TEKRONY, D.M.; EGLI, D.B. Relationship between laboratory indices of soybean seed vigor and field emergence. Crop Science, v.17, n.4, p. 573-577, 1977.

TOMES, L.T.; TEKRONY, D.M.; EGLI, D.B. Factors influencing the tray accelerated aging test for soybean seed. Journal of Seed Technology, v.12, n.1, p.24-36, 1988.

VIEIRA, R.D.; CARVALHO, N.M. Testes de vigor em sementes. Jaboticabal: FUNEP, 1994. 164p. 
VILLIERS, T.A. Ageing and the longevity of seeds infield conditions. In: HEYDECKER, W. Seed Ecology. Nottinghan: ISA, Pennsylvania State University Press, 1973. p.265-88.

WEGES, R.; KARSEN, C.M. The influence of redesiccation on dormancy and $\mathrm{K}^{+}$ leakage of primed lettuce seeds. Israel Journal Botany. v.39, n4-6, p. 327336, 1990.

WILSON, D.O.; McDONALD, M. B. The lipid peroxidation model of ageing. Seed Science and Technology, v.14, n. 2, p.269-300, 1986.

WOOD, I.M. Response of seedlings of soybean, sunflower and sorghum to added mineral nutrients. Australian Journal Experimental Agriculture. v.30, n.6, p.833-839, 1990.

WOODSTOCK, L.W. Physiological and biochemical tests for seed vigor. Seed Science and Technology, v.1, n.1, p.127-157, 1973.

WOODSTOCK, L.W. Seed imbibition: a critical period for successful germination. Journal of Seed Technology, v.12, n.1, p.1-15, 1988.

WOODSTOCK, L.W.; FURMAN, K.; LEFFLER, H.R. Relationship between weathering deterioration and germination, respiratory metabolism, and mineral leaching from cotton seeds. Crop Science. v.25, n. 3, p.459-466, 1985.

ZHANG, M.; MAEDA, Y.; FURIHATA, Y. NAKAMAR, Y.; ESASHY, Y. A mechanism of seed deterioration in relation to the volatile compounds evolved by dry seeds themselves. Seed Science Research, v.4, n.1, p.4956, 1994. 
ZONTA, E.P.; MACHADO, A.A. Sistema de análise estatística para microcomputadores - SANEST. Pelotas: UFPel, 1984. 